UNIVERSIDADE DE BRASÍLIA

Centro de Excelência em Turismo

\title{
O ECOTURISMO COMO INSTRUMENTO DE CONSERVAÇÃO AMBIENTAL E VIABILIDADE ECONÔMICA PARA RPPNS: Um estudo de caso no SVS Vagafogo.
}

Patrícia da Cunha Albernaz

Manoel Cláudio da Silva Junior

Brasília, DF, maio de 2003 


\section{UNIVERSIDADE DE BRASÍLIA}

Centro de Excelência em Turismo

\section{O ECOTURISMO COMO INSTRUMENTO DE CONSERVAÇÃO AMBIENTAL E VIABILIDADE ECONỐMICA PARA RPPNs: Um estudo de caso no SVS Vagafogo.}

Patrícia da Cunha Albernaz

Manoel Cláudio da Silva Junior

Monografia apresentada ao Centro de Excelência em Turismo da Universidade de Brasília como requisito parcial para a obtenção do certificado de Especialista em Ecoturismo

Brasília, DF, maio de 2003 
Albernaz, Patrícia C.

Ecoturismo como Instrumento de Conservação

Ambiental e Viabilidade Econômica para RPPNs: um estudo de caso na SVS Vagafogo / Patrícia da Cunha Albernaz.

Brasília: UnB/CET, 2003 p. : il.

Monografia (Especialização) - Universidade de Brasília, Centro de Excelência em Turismo, 2003.

1. Ecoturismo. 2. RPPN. 3. Conservação Ambiental. - Monografia. 
Dedico esta monografia à minha mãe que sempre esteve ao meu lado nos momentos mais difíceis e nos momentos mais alegres da minha vida. 


\section{Agradecimentos}

À minha mãe e irmã que me tranqüilizaram nos meus momentos de ansiedade

Aos meus amigos, principalmente, à Adriana, à Luciane e ao Eduardo. Sem eles esse trabalho não teria sido possível.

Ao Evandro e à Catarina que me receberam de braços abertos. Às ONGs FUNATURA/DF e NATIVA/GO pela atenção que me dedicaram.

Ao Pedro e à Graça, pela ajuda, atenção e paciência, sempre.

E ao meu orientador, Manoel Cláudio, que "fez acontecer".

Muito obrigada. 


\section{Resumo}

O Ecoturismo tem se inserido, cada vez mais, nas políticas nacionais de promoção do desenvolvimento econômico e social, configurando-se como valiosa alternativa de Desenvolvimento Sustentável. Neste Contexto, as áreas protegidas ocupam espaço relevante para o desenvolvimento do Ecoturismo, sendo os principais atrativos dessa indústria. $O$ objetivo do presente trabalho é avaliar o ecoturismo como um instrumento de conservação ambiental e de sustentabilidade econômica para as Reservas Particulares do Patrimônio Natural. Diante da importância desses dois aspectos, é necessário saber como o ecoturismo vem ocorrendo e se este realmente atende as perspectivas de um retorno ambiental, social, cultural e econômico desejável. Para tanto foi realizado um estudo de caso, no Santuário de Vida Silvestre da Fazenda Vagafogo, onde foram analisados o desenvolvimento da atividade ecoturística, dentro dos princípios de sustentabilidade definidos no trabalho, e a efetividade do manejo dessa reserva privada através da utilização de uma metodologia baseada em dois autores, Alderman (1994) e Mesquita (1999; 2000) que trabalharam especificamente com a questão de reservas privadas na América Latina e na África. A pesquisa concluiu que o Santuário de Vida Silvestre Vagafogo tem cumprido seu papel tanto no desenvolvimento sustentável do ecoturismo como no esforço de conservação e que o ecoturismo tem se mostrado um ótimo instrumento de viabilidade e sustentabilidade econômica e ecológica para as RPPNs. 


\section{Abstract}

Ecotourism has been increasing it's participation in national politics regarding social and economic development showing itself as a valuable alternative for Sustainable Development. In this matter, protected areas are of great importance for the Ecotourism development and are the main attractives offered by this branch. This work's objective is to access Ecotourism as a tool for environmental conservation and economic sustainability for private reserves (RPPN). To comprehend the importance of both of theses aspects some knowledge on how Ecotourism is going on and if it's producing environmental, social, economic and cultural growth is necessary. Upon these statements, a case study was carried out to analyze the development of the ecotouristic activity in the "Vagafogo" farm. The research involved was based on sustainable activities defined in this work and upon the effectiveness of the local management. The methodology strategies were inspired by Alderman (1994) and Mesquita (1999; 2000), scientists that have worked with private reserves in South America and Africa. It was concluded that the "Vagafogo" farm has been developing a good task when it comes to sustainable Ecotourism and conservation effort. This strategy has been an excellent tool to maintain the private reserve's economic and environmental sustainability. 


\section{Sumário}

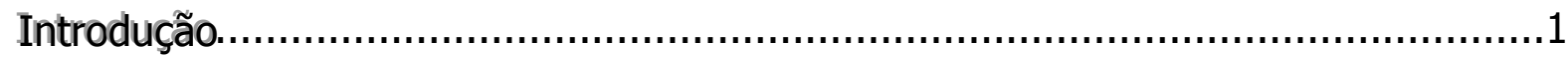

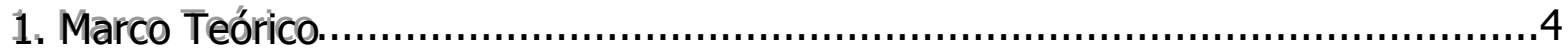

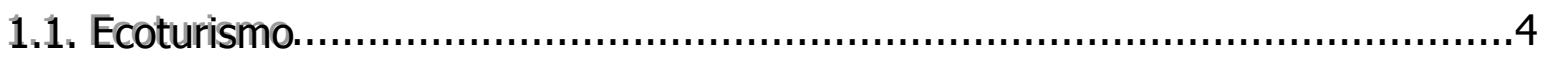

1.2. Unidades de Conservação Ambiental.....................................................

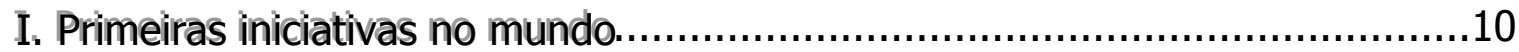

II. Primeiras îniciativas no Brasil.............................................................12

III. Situação Atual da conservação no Brasil................................................15

1.3. Reserva Particular do Patrimônio Natural................................................18

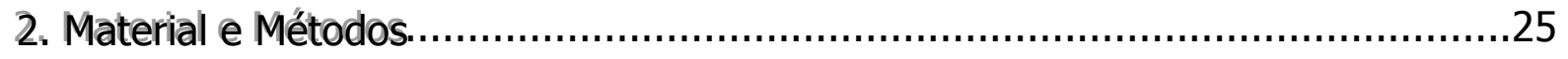

2.1. Santuário de Vida Silvestre Vagafogo.......................................................25

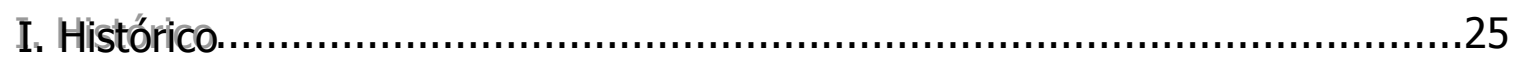

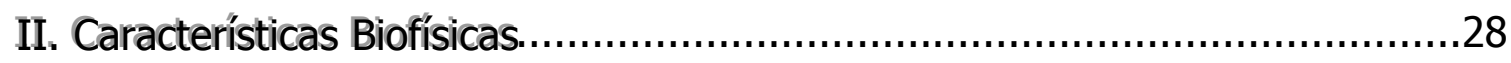

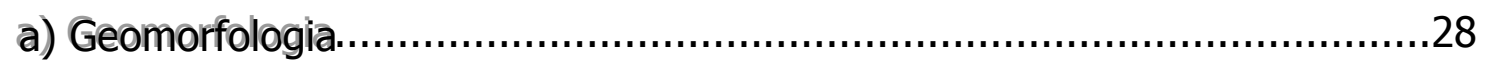

b) Clima

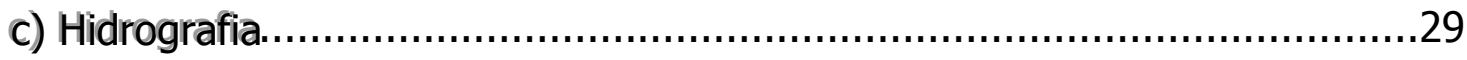

d) Solos

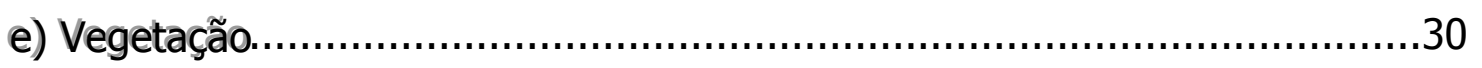

f) Fauna

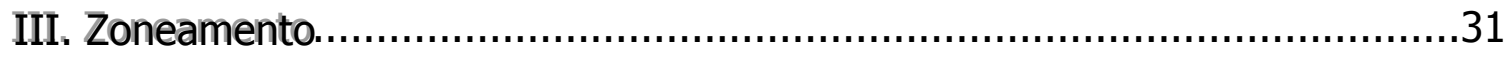

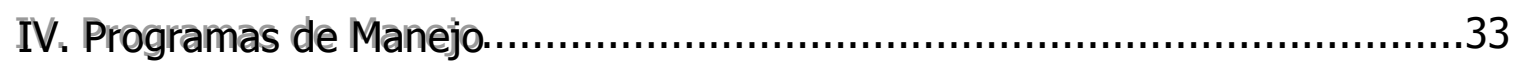

a) Programa de Manejo do Meio Ambiente..................................................33

b) Programa de Uso Público.................................................................3

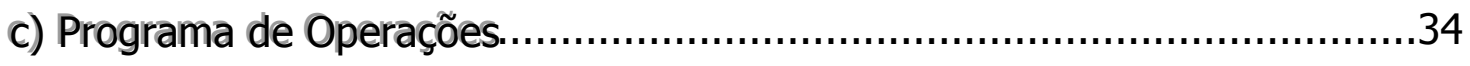

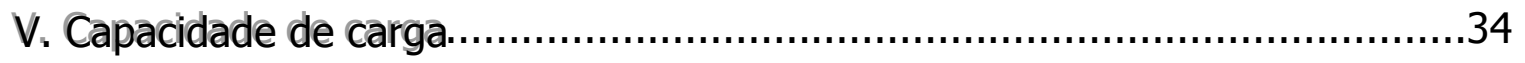

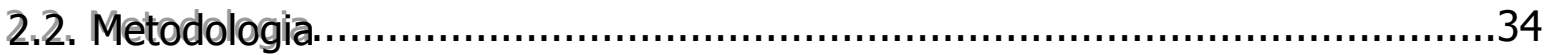

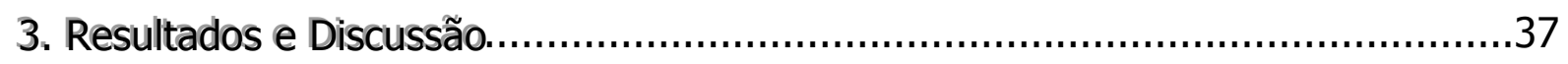

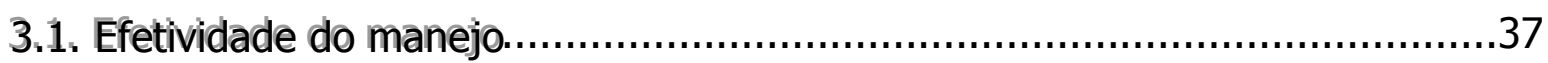

3.2. Desenvolvimento do Ecoturismo ...........................................................40

4. Conclusã̃o e Recomendaçỗes.........................................................................43 


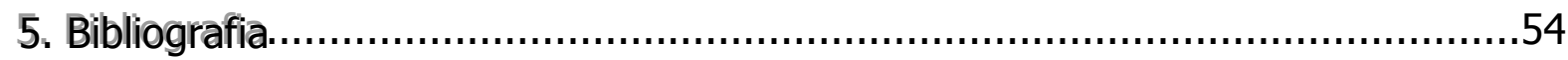

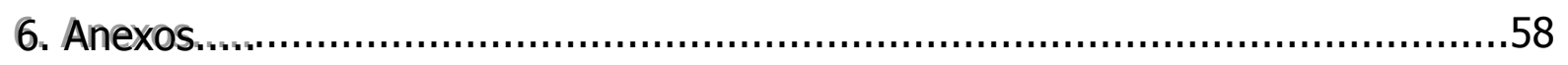

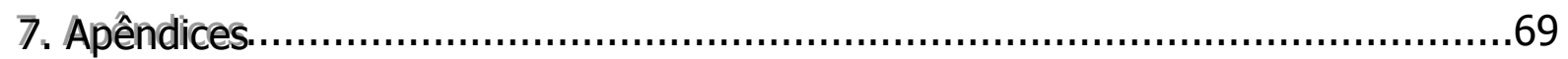




\section{Lista de Ilustraçõ̃es}

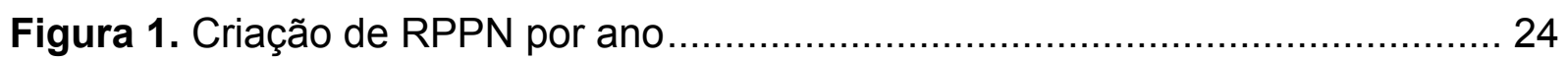

Tabela 1. Reservas Particular do Patrimônio Natural por bioma............................. 25

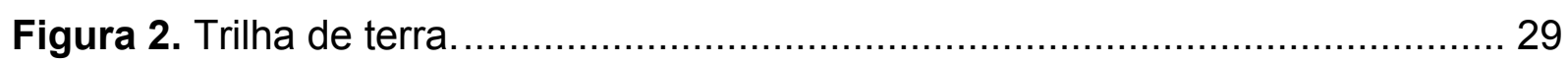

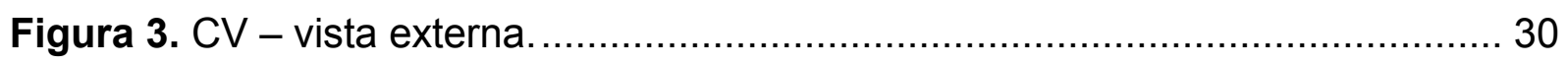

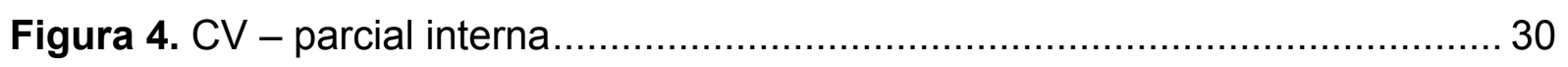

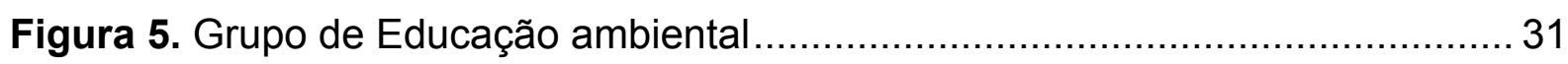

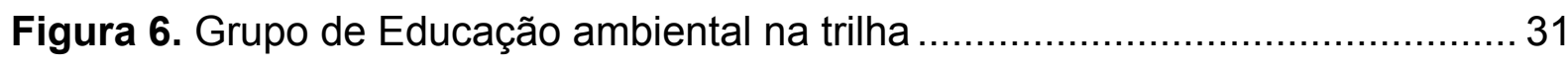

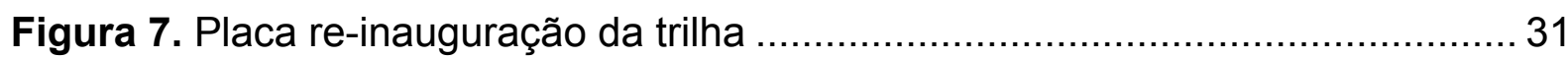

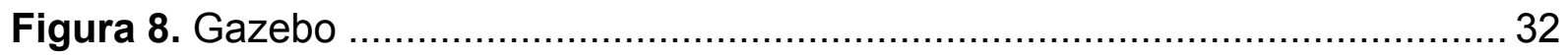

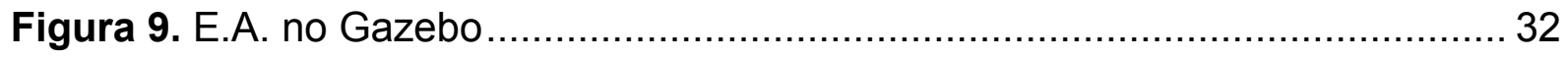

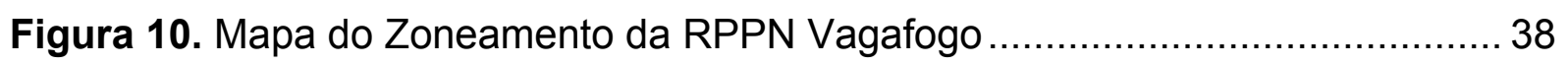

Figura 11. Mapa do Zoneamento da Fazenda Vagafogo ...................................... 39

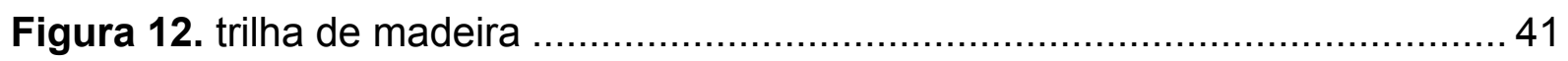

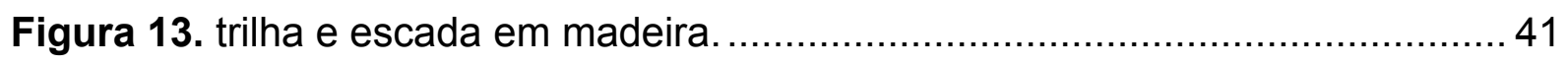

Tabela 2. Matriz de Âmbitos, variáveis e sub-variáveis ....................................... 43

Tabela 3. Efetividade do Manejo por âmbitos..................................................... 45

Tabela 4. Número de visitantes por anos e crescimento em \% ............................... 49

Figura 15. Produtos à venda no Centro de Visitantes .......................................... 50 


\section{Introdução}

A criação de Parques Nacionais (PNs) e demais áreas naturais protegidas tem sido um dos principais elementos de estratégia para a conservação da natureza, em todo o mundo (DIEGUES, 1997). Desde a criação do Parque Nacional de Yellowstone, o objetivo dessas áreas está associado à idéia de contemplação, de lazer e, conseqüentemente, de turismo.

Para Serrano (1997, p. 100), "a realidade das grandes cidades e o estresse da vida moderna tem gerado demanda cada vez mais crescente por atividade em ambientes naturais, dos quais as Unidades de Conservação (UCs) representam talvez os espaços mais significativos e importantes". Aliado a isso, a conscientização da sociedade relativamente às questões ambientais também tem contribuído para o crescimento dessa demanda.

Dessa forma, o ecoturismo tem se configurado como uma das atividades econômicas que mais interessa à conservação do meio ambiente e ao desenvolvimento sustentável (WIEDMANN, 1997). A atividade do ecoturismo deve abranger, com sua conceituação, a dimensão do conhecimento da natureza, a experiência educacional interpretativa, a valorização das culturas tradicionais locais e a promoção do desenvolvimento sustentável.

Porém para o ecoturismo ser estratégia de conservação viável, este deve conduzir ao desenvolvimento econômico sem no entanto afetar os recursos naturais dos quais depende. Por conseguinte, duas grandes condições devem ser cumpridas: ecoturismo deve ajustar-se aos requisitos conservacionistas e deve ser lucrativo e financeiramente sólido (ALDERMAN, 1994).

Nesse sentido, as terras privadas dedicadas ao ecoturismo ou à educação podem representar parte importante das estratégias globais de conservação para os países em desenvolvimento. Para Alderman (1994), os proprietários de reservas privadas dedicadas ao ecoturismo possuem fortes incentivos para manter a integridade de suas áreas naturais visto que a continuidade do sucesso de seus negócios depende da qualidade ambiental do local. 
Para Fenell (2002) o simples fato do local ser identificado como área protegida e, conseqüentemente, incluído no conceito de local de relevante beleza natural e de elevada preservação, já empresta ao lugar caráter de atrativo, gerando demanda pelo seu uso recreativo.

Dessa forma, a união dessas duas propostas - Ecoturismo e Reserva Particular do Patrimônio Natural - pode ser vista como uma relação de troca e ajuda mútua, já que tanto um quanto o outro se beneficiam dessa relação.

Por parte das Reservas Particulares do Patrimônio Natural (RPPN), o ecoturismo pode proporcionar a viabilidade e até mesmo a justificativa econômica para sua criação, sem, no entanto, ter seu objetivo maior - a conservação ameaçado pelo desenvolvimento da atividade econômica. O ecoturismo também pressupõe a seleção dos turistas que o praticam e, sendo mais especializado, gera mais lucro por visitante do que o turismo em massa, podendo ter um número reduzido de visitantes por vez, e assim, ser mais compatível com as reduzidas dimensões normalmente atingidas por RPPNs. O Ecoturismo também oferece vasto campo para o desenvolvimento de projetos sociais, aliando interesses.

Já pelo lado do ecoturismo, as RPPNs possibilitam uma gama maior de áreas naturais de mais fácil acesso, pois multiplicam a existência de áreas conservadas, com qualidade ambiental para a prática do ecoturismo, diminuindo a pressão sobre os grandes parques e ao mesmo tempo diminuindo, em termos gerais, o impacto sobre o meio ambiente, visto que, ao contrário de concentrar a demanda em um só local, como um PN, pulveriza essa demanda em várias unidades menores, reduzindo o impacto sobre o ecossistema como um todo.

Assim, do ponto de vista do Ecoturismo, as RPPNs podem oferecer amplo leque de áreas com qualidade tanto em termos biofísicos como administrativos para o desenvolvimento dessa prática, visto que as iniciativas privadas e em pequena escala tendem a ter estrutura mais flexível e dinâmica, podendo focar suas atenções e fundos mais objetivamente nos problemas.

Proprietários do sul da Bahia, por exemplo, estão descobrindo que associar seus empreendimentos (turísticos) à iniciativa de conservação pode valorizar seu negócio e ser um diferencial de mercado (MESQUITA \& LEOPOLDO, 2002). 
Assim a objetivo do presente trabalho é constatar o ecoturismo como instrumento de conservação e de sustentabilidade econômica para as Reservas Particulares. Diante da importância desses dois contextos é necessário saber como o ecoturismo vem ocorrendo e se ele realmente atende as perspectivas de retorno ambiental, social, cultural e econômico desejável. Para tanto foi realizado um estudo de caso onde foram analisados o desenvolvimento da atividade ecoturística, dentro dos princípios de sustentabilidade definidos no trabalho, e a efetividade do manejo dessa reserva privada.

A área estabelecida para o estudo de caso foi o Santuário de Vida Silvestre da Fazenda Vagafogo, situado em Pirenópolis, GO. Essa área está decretada como uma RPPN desde 1990 e vem recebendo visitação desde 1992.

Com os resultados pretende-se gerar conhecimento no campo do Ecoturismo e na esfera das políticas de criação de reservas privadas; colaborar com o setor privado nos processos de decisão, incentivando o empreendedorismo no que diz respeito ao ecoturismo e às RPPNs; colaborar para a reavaliação do Plano de manejo da reserva; e, finalmente, contribuir para a promoção da idéia de conservação e de desenvolvimento sustentável. 


\section{Marco Teórìco}

\subsection{Ecoturismo}

A indústria do turismo é, na atualidade, a atividade que apresenta os mais elevados índices de crescimento no contexto econômico internacional. Situando-se entre os maiores contribuintes do Produto Interno Bruto Mundial, movimenta cerca de US\$ 3,5 trilhões anualmente e, apenas na última década, expandiu sua atividade em 57\% (EMBRATUR, 1994).

Segundo o Conselho Mundial de Viagens e Turismo, que congrega as maiores empresas multinacionais do setor, o mercado turístico mundial empregou, em 1991, 183 milhões de pessoas. No período de 1985 a 1993, apesar da recessão mundial, o número de turistas que empreendeu viagens internacionais passou de 380 para 500 milhões (EMBRATUR, 1994). A Organização Mundial do Turismo OMT - estimou em 595 milhões a quantidade de turistas, em 1997 (TIES, 2000). No que concerne aos ganhos financeiros provenientes do turismo internacional, o valor em 1970 que era de US\$ 18 bilhões, subiu para 324 bilhões em 1993 (EMBRATUR, 1994) e para US $\$ 425$ bilhões em 1997 (TIES, 2000).

A OMT estima que haverá um crescimento de $4,3 \%$ ao ano nas próximas duas décadas quanto ao número de turistas e que as receitas advindas do turismo internacional terão crescimento de $6,7 \%$ ao ano (TIES, 2000). Verifica-se assim, que o turismo se impôs nos últimos anos como o setor econômico que mais movimenta dinheiro no mundo. Isso significa que, abaixo do setor de turismo e viagem, estão a informática, a industria aeroespacial, a industria automobilística e uma série de outras atividades econômicas de alta tecnologia (BARROS II, 1996).

Neste contexto, o Ecoturismo é o segmento que apresenta o maior crescimento ao longo dos anos. Apesar da ausência de estatísticas oficiais relativas à dimensão deste mercado, o seu crescimento é estimado em cerca de $20 \%$ ao ano, já representando $10 \%$ das atividades turísticas totais (EMBRATUR, 1994). 
Porém a inexistência da definição globalmente aceita para o Ecoturismo, com o conseqüente enquadramento das atividades que devem ser consideradas neste segmento, vem dificultando a existência de estudos cientificamente fundamentados e conclusivos sobre a matéria (EMBRATUR, 1994), fazendo com que as estatísticas sobre o Ecoturismo sejam divergentes.

Mesmo assim, o Ecoturismo tem se inserido, cada vez mais, nas políticas de promoção do desenvolvimento econômico e social, configurando-se, no momento, como importante alternativa de desenvolvimento econômico sustentável. $\mathrm{O}$ adequado aproveitamento dos variados ecossistemas existentes, e ainda pouco explorados, pode propiciar a abertura de novas alternativas econômicas e a conseqüente melhoria das condições de vida das populações envolvidas, além de reduzir os impactos negativos causados pelo turismo tradicional (EMBRATUR, 1994).

O interesse no Ecoturismo é excelente oportunidade de fazer uso do turismo como ferramenta para a proteção de ecossistemas naturais, agregando valor socioeconômico ao estado original do ecossistema (FILION, FOLEY \& JACQUEMOT, 1994).

Em pesquisa feita no Canadá foi revelado que $45 \%$ dos canadenses aproveitam a vida selvagem e gastam dinheiro em atividades ligadas ao tema durante viagens que eram primeiramente para outros fins, como negócios ou lazer. "Claramente, flora, fauna e áreas naturais não são sempre a principal razão pela qual os turistas viajam. Contudo constituem importante atração para certos destinos em detrimento de outros, sendo também importantes para proporcionar ou aumentar a satisfação dos turistas uma vez que chegam no destino."1 (FILION, FOLEY \& JACQUEMOT, 1994, p. 237)

A Costa Rica, por exemplo, país considerado número 1 em Ecoturismo por trinta e cinco dos mais importantes editores e jornalistas americanos especializados, possui cerca de $25 \%$ de seu território constituído por áreas protegidas - públicas ou privadas, sendo que $75 \%$ dos turistas visitam pelo menos um parque nacional (MOURÃO, 2001).

\footnotetext{
${ }^{1}$ Tradução da autora.
} 
Segundo Alderman (1994) existe atualmente o reconhecimento crescente de que a preservação ambiental deve incluir aspectos econômicos que tanto influenciam os programas governamentais quanto os incentivos econômicos para a exploração dos recursos naturais. Para a autora, a manifestação dessa perspectiva é o recente interesse no Ecoturismo como meio de promover o desenvolvimento sustentável enquanto, ao mesmo tempo, cria justificativa econômica para a preservação de terras naturais e selvagens.

Atualmente existem vários conceitos para Ecoturismo. Não raro cada autor acaba elaborando sua própria definição. Para Boo (1994), o Ecoturismo emergiu da convergência entre duas tendências mundiais: a conservação e a industria de viagem. Por parte da conservação, existe hoje a tendência de integração entre conservação e desenvolvimento econômico como meio de se atingir um desenvolvimento sustentável. Nesse sentido, o Ecoturismo é uma forma de gerar recursos a partir da 'venda' de destinos naturais ao mesmo tempo em que os conserva. No âmbito da industria de viagem, está havendo a mudança de atitude e de valores: o turismo tem se orientado cada vez mais para a natureza. Grande parte dessa mudança é devida ao interesse mundial pelo meio ambiente e fatores a ele relacionados, como animais em extinção, desmatamento etc.

Fennell (2002, p.42) no seu ensaio de uma análise histórica do conceito de Ecoturismo e da identificação das principais características e princípios do termo fez levantamento de vários autores. Para ele a base conceitual do termo remonta a década de 1960, quando aparece no trabalho de Hetzer (1965) ${ }^{2}$, no qual ele identificava quatro pilares para um turismo mais responsável: impacto ambiental mínimo; mínimo impacto e máximo respeito às culturas anfitriãs; benefícios para a comunidade anfitriã e satisfação do turista (FENNELL, 2002, p.42).

Já para muitos autores, Héctor Ceballos-Lascuráin foi o primeiro a usar e definir o termo Ecoturismo, no início da década de 1980. De fato, a primeira vez que ele recorreu ao termo Ecoturismo foi em 1983 na tentativa de descrever o fenômeno que vinha ocorrendo na Península de Yucatán, no México, de um número crescente de visitantes, na maioria vindos dos Estados Unidos, interessados principalmente na observação de pássaros, e da possibilidade desses visitantes impulsionarem a

\footnotetext{
${ }^{2}$ HETZER, N.D. Environment, tourism, culture. LINKS, 1965. reeditado em Ecosphere, 1970. 1(2): 1-
} 3. 
economia rural local, criando novos empregos e ajudando a preservar o ecossistema local. (RON MADER, 2000)

Posteriormente, em 1987, Héctor Ceballos definiu o Ecoturismo como:

"aquella modalidad del turismo que consiste en viajar a áreas naturales relativamente sin perturbar con el objeto específico de admirar, disfrutar y estudiar su paisaje, su flora y su fauna silvestres, así como las manifestaciones culturales (tanto presentes como pasadas) que allí puedan encontrarse. En estos términos, el Ecoturismo implica un enfoque científico, estético o filosófico, sin que ello signifique que el ecoturista deba ser un científico, un artista o un filósofo profesional. Lo relevante aquí es que la persona que practica el Ecoturismo tiene la oportunidad de estar inmersa en la Naturaleza de manera muy distinta a la que usualmente se presenta en la vida urbana cotidiana. Dicha persona a la larga adquirirá una conciencia y un conocimiento del medio ambiente natural ( $y$, por extensión, del cultural), convirtiéndose así en alguien genuinamente involucrado en los temas conservacionistas". (CEBALLOS-LASCURÁIN em entrevista a RON MADER, 2000)

Desde sua introdução, o termo Ecoturismo ganhou amplo uso, principalmente devido ao forte apelo inserido nessa denominação.

Diante da diversidade de autores e de conceitos sobre o Ecoturismo e à luz de uma vasta revisão literária, Fennell (2002) criou sua própria definição de Ecoturismo, na tentativa de abranger os aspectos mais importantes do fenômeno, como sendo:

"uma forma sustentável de turismo baseado nos recursos naturais, que focaliza principalmente a experiência e o aprendizado sobre a natureza; é gerido eticamente para manter um baixo impacto, é não-predatório e localmente orientado 
(controle, benefícios e escala). Ocorre tipicamente em áreas naturais, e deve contribuir para a conservação ou preservação destas." (Fennell, 2002, p.52)

No Brasil, em 1994, diante da importância da atividade turística para a economia e da necessidade de ordenar sua realização, foi criado o grupo de trabalho interministerial formado por representantes do Ministério da Industria, Comércio e Turismo e do Ministério do Meio Ambiente, dos Recursos Hídricos e da Amazônia Legal, no intuito de propor uma Política Nacional de Ecoturismo. Nesse mesmo sentido foi definido o conceito nacional de Ecoturismo como sendo:

"um segmento da atividade turística que utiliza, de forma sustentável, o patrimônio natural e cultural, incentiva sua conservação e busca a formação da consciência ambientalista através da interpretação do ambiente, promovendo o bem estar das populações envolvidas." (DIRETRIZES PARA UMA POLÍTICA NACIONAL DE ECOTURISMO, 1994.)

Nessa definição estão inseridos os quatro fundamentos básicos que devem nortear o desenvolvimento do Ecoturismo ${ }^{3}$, que são:

- a conservação: visto que para garantir o meio ambiente sadio, a conservação e o uso sustentável dos recursos naturais são essenciais. Assim, a atividade turística deve sempre primar por um manejo do turismo de modo a assegurar a conservação e a sustentabilidade do ambiente visitado;

- o desenvolvimento sustentável: Este conceito de Desenvolvimento Sustentável - DS, deve ser entendido como o significado de melhorar a qualidade de vida humana dentro dos limites da capacidade de suporte dos ecossistemas do nosso planeta (SOUZA, 2002). Assim, para ser compatível com os conceitos do DS, o Ecoturismo deve ser planejado, gerido e empreendido de modo a evitar danos ao meio, sendo ambientalmente

${ }^{3}$ Adaptado pela autora a partir de WWF (2001). 
sustentável, economicamente viável e socialmente eqüitativo. Dessa forma visa atender às necessidades do presente sem comprometer as necessidades das gerações futuras;

- a valorização da comunidade local: o turismo deve não só respeitar e valorizar as culturas locais, seus conhecimentos e experiências, como também deve buscar benefícios e promover oportunidades de desenvolvimento para a comunidade local;

- a promoção de consciência ambiental: a conscientização ambiental é a base para o Ecoturismo, que deve estar associado à prática de interpretação ambiental que desenvolva a consciência sobre o meio ambiente, reforçando atitudes, valores e medidas que favoreçam a conservação e 0 desenvolvimento sustentável por parte de todos. A interpretação alia os interesses do turismo com os interesses da conservação, de forma a promover ampla campanha de educação e esclarecimento do visitante (MURTA, 1996).

Para Bürgi \& Marinho (1997), o crescente interesse pelas áreas naturais protegidas é conseqüência de quase duas décadas de militância ambientalista internacional, aliada à globalização das informações sobre a crescente degradação ambiental, gerando o amadurecimento da consciência ecológica e, conseqüentemente, o crescimento da demanda por atividades ecoturísticas. De fato, a percepção acerca da necessidade urgente de proteção e recuperação dos recursos naturais influencia a escolha dos destinos turísticos, fazendo com que a demanda turística volta-se, cada vez mais, para as áreas protegidas.

Nesse contexto, as áreas protegidas representam o papel fundamental para o desenvolvimento tanto do turismo como do Ecoturismo, sendo elas os principais atrativos dessa indústria. O parque Nacional do Yellowstone, por exemplo, recebe hoje 3 milhões de visitantes ao ano. No Brasil, o do Parque Nacional do Iguaçu registra aproximadamente 1,5 milhões de visitantes por ano (MMA, 2003c).

Entretanto, a oferta dos destinos ecoturísticos depende não só da existência de áreas de elevado valor ecológico e cultural, mas também da maneira como essas áreas são geridas, da existência de infra-estruturas adequadas e da 
disponibilidade de recursos humanos capacitados. Fatores que nem sempre estão presentes nas unidades de conservação (UCs) federais (EMBRATUR, 1994).

\subsection{Unidades de Conservação Ambiental}

Diante da importância e da dimensão das unidades de conservação para o Ecoturismo, faz-se necessário, então, esclarecer as características e os objetivos iniciais das unidades de conservação e entender a evolução desse instrumento ao longo dos anos.

\section{Primeiras iniciativas no mundo}

No mundo ocidental, a prática de estabelecer áreas com o objetivo de manter atributos da natureza e da vida silvestre remontado à Idade Média, quando as classes dominantes da antiga Roma e da Europa Medieval destinavam áreas para o seu uso exclusivo. O objetivo básico desses antepassados era segregar recursos naturais da fauna e seu habitat para o exercício da caça ou para reservar recursos florestais e madeireiros com fins utilitaristas para proveito da realeza e da aristocracia rural. A Floresta da Bialowieza, por exemplo, foi estabelecida como reserva para a proteção do bisão europeu pelo Rei da Lituânia, em 1423. Na Suíça, em 1569, foi criada uma reserva para proteger o antílope europeu e no século XVIII, a França criou os Parques Reais, que foram inclusive abertos ao público. (ROCHA, 2002)

Movimentos mais abrangentes para a proteção de áreas naturais como espaços de uso público parecem só ter surgido após a Revolução Industrial, devido a grande pressão e a rápida transformação que a paisagem vinha sofrendo, em decorrência da expansão da demanda por matéria prima. E também por causa do surgimento de uma classe crescente de pessoas em rotinas estressantes de trabalho em fábricas, que necessitavam de espaços para recreação ao ar livre 
(MILANO, 2000).

Com o advento dos Parques Nacionais, houve mudança profunda na filosofia de áreas naturais protegidas. Os Parques Nacionais (PNs) surgiram nos Estados Unidos da América em 1872 e tinham como finalidade a proteção de áreas naturais de notável beleza cênica. Neles estava vedado qualquer tipo de exploração direta dos recursos, de modo a serem usufruídos pela sociedade como um todo, através de atividades recreativas, contemplativas etc, com a perspectiva de perenidade, preservando o que já era considerado herança das futuras gerações. Desta forma, os Parques Nacionais não se destinavam mais a um grupo privilegiado, mas à sociedade de maneira geral. (ROCHA, 2002)

Influenciados por Yellowstone e pelos EUA, outros países aderiram ao mesmo procedimento. O Canadá criou seu primeiro parque em 1885, a Nova Zelândia em 1894, a Austrália, a África do Sul e o México, em 1898. Na América do Sul, a Argentina foi a precursora, criando um parque nacional em 1922, em terras doadas para este fim em 1903. O Chile aderiu em 1926, o Equador em 1934 e a Venezuela e o Brasil somente no ano de 1937. (ROCHA, 2002; IBAMA/FUNBIO, s/d) Em menos de um século, a maioria dos países do mundo havia destinado áreas para proteção.

Depois disso, os conceitos de Parques Nacionais e demais categorias de Unidades de Conservação foram sendo forjados em sucessivos eventos nacionais e internacionais, principalmente nas Conferências Mundiais realizadas a cada 10 anos, tendo a primeira delas ocorrido em Seatlle (EUA) em 1962. Estas conferências tiveram grande repercussão e influenciaram a conduta e as políticas internas da maioria dos países. Em 1972, por exemplo, durante o II Congresso Mundial de Parques Nacionais, realizado no PN de Yellowstone, os tópicos de maior interesse foram a representatividade ecossistêmica dos biomas e a conservação da diversidade biológica. Já no III Congresso Mundial de Áreas Protegidas, realizado em Bali, Indonésia, em 1982, foi levantada a necessidade de coordenar a política de desenvolvimento com as políticas de criação de áreas protegidas, num reconhecimento de que, muitas vezes, as políticas de desenvolvimentos criam sérias pressões sobre as áreas protegidas. Também teve relevância a melhoria do padrão de vida das populações locais vinculada às unidades de conservação. (ROCHA, 
Em 1992, na Conferência das Nações Unidas sobre o Meio Ambiente e Desenvolvimento, a Rio-92, foi elaborada a Agenda 21. Este documento, entre outros pontos, ressalta a importância de integrar estratégias para a conservação da diversidade biológica e o uso sustentável dos recursos naturais às estratégias dos planos nacionais de desenvolvimento. O cuidado com o patrimônio natural, a sua exploração racional com vistas à sua conservação e a preservação dos processos naturais e da biodiversidade, passaram a ser considerados fundamentais dentro de um novo paradigma: o do desenvolvimento sustentável. Assim, a partir desse momento, as áreas protegidas estavam definitivamente inseridas no processo de desenvolvimento sustentável. (ROCHA, 2002)

Com o passar do tempo, as áreas protegidas se consolidaram como uma das formas mais eficientes de garantir a preservação de amostras significativas dos ecossistemas naturais, de conservação da biodiversidade e de manutenção dos processos naturais vitais, frente ao irrefreável avanço do processo de desenvolvimento (EMBRATUR, 1994).

No mundo inteiro, aproximadamente 750 milhões de hectares de ecossistemas terrestres e marinhos são objeto de alguma forma de proteção, o que totaliza cerca de $1,5 \%$ da superfície da Terra, ou, $5,1 \%$ da extensão territorial dos países (WRI/UICN/PNUMA, 1992 citado por MMA, 2003b).

Em contrapartida, 11 milhões de hectares de florestas são derrubadas anualmente (GÓMEZ-POMPA \& BURLEY, 1991). Isso gera grande pressão nas UCs já estabelecidas que muitas vezes tornam-se ilhas de vegetação nativa, privadas de fluxogênico (pólen e sementes) de plantas e animais que tem seu trânsito confinado a esses remanescentes.

\section{Primeiras iniciativas no Brasil}

No Brasil, desde o início do século XIX, já era comum a preocupação com a forma como se dava a exploração agropecuária. Ainda na segunda metade do século XIX, teve início forte pressão da elite intelectual e científica do país, sendo 
reconhecida a influência do engenheiro, político, abolicionista e madeireiro, André Rebouças, pela criação dos Parques Nacionais na llha do Bananal e em Sete Quedas (PR) (DEAN,1996).

Em 1925, sob forte pressão interna e externa, foi organizado o Serviço Florestal Federal. Por essa época, início do século $X X$, também já havia crescido o rol de pessoas que pressionavam e influenciavam os burocratas e a opinião pública nacional em prol da conservação. O Centro Excursionista Brasileiro, fundado em 1919 e sediado no Rio de Janeiro, por exemplo, cujos guias haviam sido credenciados como guardas florestais nos primeiros dias do Serviço Florestal, exerceu intensa pressão, juntamente com outros clubes que vieram a ser criados, no sentido de proteção e socialização das áreas onde se desenvolviam ou com potencial para a prática de esportes. Diversas organizações diretamente envolvidas com a conservação parecem ter influenciado a legislação inicial do período Vargas a Sociedade de Amigos de Alberto Torres, os Clubes de Amigos da Natureza, a Sociedade Geográfica do Rio de Janeiro e a Sociedade de Amigos das Árvores, são alguns exemplos (DEAN, 1996, p.275).

A Sociedade de Amigos das Árvores, fundada em 1931, protestou contra o desmatamento do Rio de Janeiro e convocou a primeira Conferência Brasileira sobre Proteção da Natureza em 1934. Nesta oportunidade analisou-se a situação estado por estado e, para o Rio de Janeiro, estimou-se já não haver mais nenhuma floresta primária, entendida como aquela que não sofreu intervenção antrópica no sentido de uma exploração drástica. No Espírito Santo e Minas Gerais, a destruição da floresta foi calamitosa e em São Paulo, apesar do reflorestamento, a destruição era generalizada (ROCHA, 2002). Segundo Souza (2002, p.77), o Rio Grande do Sul possui menos de $5 \%$ de sua floresta primária; Santa Catarina e Paraná $7 \%$; São Paulo, Rio de janeiro e Minas Gerais entre 7 e 9\%.

Assim que, antes mesmo da publicação do Código Florestal de 1934, algumas áreas já haviam sido separadas, pelo poder público, com o propósito de proteção ou pesquisa. O Código Florestal de 1934, classificou as florestas como: 1) Protetoras - as que eram destinadas a conservar o regime das águas, evitar a erosão das terras, fixar dunas, auxiliar a defesa das fronteiras, proteger sítios de grande beleza natural e asilar espécies raras da fauna silvestre; 2) Remanescentes 
- onde estavam situados os Parques nacionais, estaduais, municipais ou pequenos parques ou bosques públicos etc; 3) Modelos - as plantadas com essências nativas ou exóticas; e, 4) de rendimento - que eram todas as demais. Com base neste instrumento foram criados os primeiros Parques Nacionais, Florestas Protetoras, Florestas Nacionais e Reservas Florestais (ROCHA, 2002, p.19).

O primeiro Parque Nacional brasileiro foi o Itatiaia, em 1937. Nasceu em torno de uma Estação de Pesquisa Botânica ou Estação Biológica mantida na área pelo menos desde 1914 pelo Jardim Botânico do Rio de Janeiro (DRUMMOND, 1997, p.15)

Parte da área que integra o Parque do Iguaçu também foi colocada sob status especial antes de se tornar PN, em outubro de 1930 pelo governo do Paraná, sendo, mais tarde, doada ao governo federal para a criação do PN do Iguaçu em 1939 (IDEM, p.15).

Nesse mesmo ano, no dia 30 de novembro, foi criado o PN da Serra dos Órgãos. Segundo Rocha (2002, p.38), "os três primeiros parques (...) têm características em comum: marcante beleza cênica, ecossistemas predominantemente florestais, facilidade de acesso e localização nas regiões Leste e Sul, de maior concentração populacional do país, (...) deixando claro o objetivo de destiná-los à visitação pública”.

Em 1965, face ao estado de devastação dos recursos florestais e à necessidade de modernizar alguns aspectos do Código Florestal de 1934, foi promulgado um novo Código Florestal (Lei $\mathrm{n}^{\circ}$ 4.771). As mudanças mais determinantes relativas às Unidades de Conservação ocorreram com a introdução da divisão conceitual entre as unidades que não permitiam a exploração direta dos recursos naturais e as unidades de uso direto.

Em 1967 foi baixada a Lei de Proteção à Fauna (Lei $n^{\circ} 5.197$ ) e criado o Instituto Brasileiro de Desenvolvimento Florestal (IBDF), vinculado ao Ministério da Agricultura, e em 1973 foi criada a Secretaria Especial de Meio Ambiente (SEMA), vinculada ao Ministério do Interior. Diferentemente de outros países, como EUA, Argentina, Canadá, Chile e do continente africano que privilegiaram áreas remotas, o Brasil priorizou o acesso fácil e a possibilidade de visitação em massa, principalmente até 1979 quando, acelerou o processo de criação de UCs na 
Amazônia (DRUMMOND, 1997).

A Lei $\mathrm{n}^{\circ}$ 9.985, promulgada no ano 2000, após quase oito anos de tramitação no Congresso Nacional, consolidou as legislações anteriores no Sistema Nacional de Unidades de Conservação da Natureza (SNUC), classificando as UCs em dois grupos: Unidades de Proteção Integral e Unidades de Uso Sustentável. Nas primeiras, está totalmente restringida a exploração ou o aproveitamento dos recursos naturais, admitindo-se apenas o aproveitamento indireto dos seus benefícios. São identificadas também como Unidades de Uso Indireto e se constituem nos Parques Nacionais, Reservas Biológicas, Estações Ecológicas, Monumentos Naturais e Refúgios de Vida Silvestre. As Unidades de Uso Sustentável admitem a exploração e o aproveitamento econômico direto dos recursos de forma planejada e regulamentada. São identificadas também como Unidades de Uso Direto e são constituídas pelas Áreas de Proteção Ambiental, Áreas de Relevante Interesse Ecológico, Florestas Nacionais, Reservas Extrativistas, Reservas de Fauna, Reservas de Desenvolvimento Sustentável e Reserva Particular do Patrimônio Natural. Cada uma destas categorias tem objetivos de manejo diferenciados, visando cobrir a maior gama de situações, para a garantia da conservação dos recursos naturais (IBAMA, 1997).

\section{Situação Atual da conservação no Brasil}

O Brasil, a Colômbia, o México e a Indonésia são os quatro países mais ricos em diversidade de fauna e flora. No Brasil, que é o campeão em número total de organismos, vivem cerca de três mil espécies de vertebrados terrestres e três mil de peixes de água doce. Aqui, são encontradas também 55 mil espécies de plantas com flores, o que equivale a $22 \%$ de todas as plantas com flores existentes no planeta. Há ainda 517 espécies de anfíbios (sapos, rãs, etc.), o que representa 12\% das espécies do mundo, 77 espécies de primatas (macacos) - 26\% do total de espécies existentes na Terra, e mais $17 \%$ das aves do mundo. Grande parte da diversidade estimada de insetos - algo em torno de 10 a 15 milhões de espécies, a maioria ainda desconhecida - encontra-se em território brasileiro. O Brasil 
ocupa o segundo lugar em número de mamíferos (524 espécies), a terceira posição em número de pássaros (1.622 espécies) e em número de palmeiras (387 espécies) e o quarto lugar em número de répteis (468 espécies) (IBAMA /FUNBIO, s/d).

Ou seja, em termos de biodiversidade, o Brasil apresenta-se com o título de detentor da maior diversidade biológica do planeta, contando com pelo menos 10 a $20 \%$ do número total de espécies do mundo (EMBRATUR, 1994).

Segundo o IBAMA (2003c), o país dispõe, hoje, de um quadro extenso de unidades de conservação. As 248 Unidades de Conservação federais de uso direto e indireto (sem adicionar as RPPNs) somam 53.217.332,87 hectares ${ }^{4}$ ou $6,23 \%$ do território continental brasileiro.

Como Unidades Federais de Proteção Integral o Brasil possui 52 Parques Nacionais, 29 Estações Ecológicas, 25 Reservas Biológicas, 2 Reservas Ecológicas ${ }^{5}$ e 1(um) Refúgio de Vida Silvestre, num total de 109 unidades de Proteção Integral, ou seja, 2,77\% do território nacional continental (IBAMA, 2003b).

Como Unidades Federais de Uso Sustentável, existem atualmente: 29 Áreas de Proteção Ambiental, 63 Florestas Nacionais, 30 Reservas Extrativistas e 17 Áreas de Relevante Interesse Ecológico $^{6}$ num total de 139 unidades, o que representa 3,52\% da área continental do Brasil (IBAMA, 2003b).

As Reservas Particulares do Patrimônio Natural somam mais 390 Unidades de Conservação, totalizando 638 Unidades de Conservação Federais ou 53.762.159,89 hectares (IBAMA, 2003a).

A soma dessas categorias totaliza $6,29 \%$ do território nacional. Mesmo as sobreposições tendo sido processadas e excluídas nessa soma, esse valor é um pouco superestimado, principalmente devido ao fato de que as APAs, muitas vezes, não se constituem em instrumentos capazes de garantir a conservação plena dos recursos, funcionando muito mais como uma tentativa de ordenamento territorial e de uso do solo, grande parte das vezes já previstos na legislação vigente. Mesmo

\footnotetext{
${ }^{4}$ Os valores referentes as áreas das UCs foram obtidos dos decretos de criação e revisão de limites, ou por meio de cálculo através de técnicas de geoprocessamento. A estatística foi realizada pela Diretoria de Ecossistemas do IBAMA, atualizada em 03/01/2003.

${ }^{5}$ Eram cinco Reservas Ecológicas, contudo duas (Raso da Catarina/BA e Jutaí-Solimões/AM) mudaram para Estação Ecológica (EE) e a outra (Juami-Jupurá/AM) foi englobada por uma EE.

${ }^{6}$ Eram 19 áreas, mas duas (Ilhas do Pinheiro e Pinheirinhos/PR e Mirici/AL) foram englobadas por outras UCs.
} 
assim, esse percentual reflete um esforço considerável de conservação in situ ${ }^{7}$ da diversidade biológica (MMA, 2002a; ROCHA, 2002).

Quanto à representatividade da proteção ambiental por biomas, a distribuição percentual de áreas de UCs federais, sem contar com as RPPNs, é a seguinte: a Amazônia ${ }^{8}$ apresenta 10,97\%, a Mata Atlântica 2,63\%, o Cerrado com 2,52\%, a Caatinga com 2,95\%, o Planalto Sul Brasileiro com 2,15\% e o Pantanal com $0,57 \%$. O Bioma Costeiro possui $13,51 \%$ de sua superfície oficialmente protegida (IBAMA, 2003d).

Como se pode observar, o total de área protegida por bioma é insuficiente para a conservação da biodiversidade brasileira, visto que, segundo as conclusões do IV Congresso Internacional de Áreas Protegidas, realizado em Caracas, na Venezuela, em 1992, a recomendação é de que haja no mínimo de $10 \%$ de áreas de proteção integral por bioma (MMA, 2003a). Já a comissão Brundtland - a Comissão Mundial de Meio Ambiente e Desenvolvimento - fixou um padrão de 12\% para todos os países em termos de quantidade de território necessário para o estabelecimento de parques e áreas protegidas, acreditando que esse padrão irá garantir um bom grau de proteção para todas as principais regiões fisiográficas da terra (FENNELL, 2002).

Como se pode verificar, dos biomas continentais, apenas a Floresta Amazônica está dentro do padrão ideal, principalmente por ter sido favorecida pela sua grande extensão, sua pouca ocupação e ao poder público ter, de certa forma, se adiantado à ocupação dessa fronteira. O Cerrado, além do reduzido percentual de UC's de Proteção Integral (1,79\%), tem sido alvo de uma intensa ocupação e uma enorme pressão sobre seus recursos naturais, agravando o estabelecimento de unidades de conservação significativas (MMA, 2003b). Ter sido situado como a principal fronteira agrícola do país é, com certeza, um dos principais problemas enfrentados pelo Cerrado na tentativa de conservação de sua biodiversidade. Tal

\footnotetext{
${ }^{7}$ Conservação in situ :quando o estoque é preservado mediante a proteção do ecossistema onde o organismo encontra seu meio natural. Conservação ex situ: que pode ser parte do organismo quando é preservado a semente, o sêmen, ou qualquer outro elemento a partir do qual será possível a reprodução do organismo preservado - ou o organismo inteiro - quando uma certa quantidade de organismos é mantida fora do seu meio natural, em plantações, jardins botânicos, zoológicos, aquários, prédios ou coleções para cultivo. Das estratégias acima mencionadas, a preservação in situ é a preferida, pois se preserva também os ecossistemas e as paisagens, o que resulta no alcance de outros tantos objetivos. (MMA, 2003b)

8 A Amazônia possuía $7,6 \%$ do território em Unidades de conservação. Com a criação do Parque Nacional Montanhas de Tumucumaque, em 2002, no Amapá esse percentual passou para 11\% 
situação já levou a um desmatamento avassalador em uma região onde as características físicas não favorecem a aptidão para a agropecuária.

Apesar de pouco valorizado, o Cerrado é considerado a savana de maior diversidade vegetal do mundo e sua riqueza em espécies de invertebrados é digna de destaque (IBAMA /FUNBIO, s/d). O Cerrado não só é o segundo maior bioma em tamanho no Brasil, mas também na América Latina. Este ocupa 24,5\% da extensão territorial do país, ou seja, mais de duzentos milhões de hectares. O cerrado abrange vários estados, variando em altitudes de 0 (zero) até 2000 metros. As principais fitofisionomias do Cerrado são o cerradão, o cerrado propriamente dito, o campo limpo, o campo sujo, as veredas e as matas de galeria. (PÁDUA, 1996)

Considerando a riqueza da biodiversidade desse bioma, só no Distrito Federal já foram estudadas mais de 233 espécies de orquídeas, número maior do que todas as espécies existentes nos Estados Unidos da América. Em número de aves, o cerrado abriga cerca de 430 espécies que correspondem a um terço do que ocorre no Brasil. E em se tratando de importância hídrica para o país, aqui está situada Águas Emendadas, onde se encontram as nascentes das Bacias Amazônica e do Prata, além da Bacia do São Francisco, sendo uma região privilegiada em recursos hídricos. (PÁDUA, 1996)

Segundo Barros II (1996), a preservação do Cerrado, das belezas que existem na região, da potencialidade genética, da qualidade das águas etc, depende de novas alternativas de exploração econômica que possibilitem aos municípios e proprietários de terras redimensionar seus projetos de desenvolvimento econômico, ao mesmo tempo que garantam a preservação da biodiversidade e da qualidade dos recursos hídricos da região. Neste contexto, torna-se presente, novamente, o valor do Ecoturismo como alternativa para a região do Cerrado, no sentido de diversificar a exploração econômica dessa região. 


\subsection{Reserva Particular do Patrimônio Natural}

Como foi argumentado anteriormente, apesar da megadiversidade, o país ainda protege pouco, quantitativa e qualitativamente, sua biodiversidade. A definição, o estabelecimento, a manutenção e a gestão de Unidades de Conservação exigem muitos recursos e apoio da sociedade e, diante de todas prioridades e situações emergenciais que o país vive, os recursos dedicados ao meio ambiente são exíguos e insuficientes. (IBAMA/FUNBIO, s/d)

Segundo Piskulich (2001), no Brasil 85\% das terras, inclusive de PNs ainda estão nas mãos de proprietários privados. E o governo não tem fundos para comprar ou proteger adequadamente as áreas privadas onde existe biodiversidade expressiva. Dados da Fundação Biodiversitas mostram que no Brasil mais de 90\% das áreas nativas estão incorporadas em propriedades particulares sob influência direta do homem, sendo primordial o envolvimento de seus proprietários na proteção de toda ou parte das suas áreas, através da criação de UCs (BIODIVERSITAS, 2003).

O avanço do debate sobre a contribuição efetiva do setor privado à conservação da biodiversidade está, pois, contextualizado não só pela legislação vigente no país, mas também pelo estado de degradação em que se encontra grande parte do território brasileiro, principalmente pelo descumprimento da legislação ambiental que incide sob a proteção dos ecossistemas em propriedades particulares, especificamente as Reservas Legais (RL) e as Áreas de Preservação Permanente (APP) (TORRECILHA \& LOUREIRO, 2000, p. 602).

"As áreas de Reserva Legal foram instituídas pelo Código Florestal com função específica de conservar o equilíbrio ecológico, mantendo regulado os regimes de chuvas, do clima, da absorção de gases, de partículas poluentes e, sobretudo, garantir as demandas das gerações futuras, especialmente no que se refere a princípios ativos de plantas medicinais que poderão representar a cura de doenças que nem existem atualmente." (SOUZA, 2002, p.77) 
Já as APP, que naturalmente seriam os arcabouços dos corredores ecológicos, que poderiam mitigar o problema da erosão genética pela possibilidade de promover a conectividade entre as diferentes áreas, foram sistematicamente incorporadas ao processo produtivo e de desenvolvimento de uma maneira geral (ROCHA, 2002).

Para Souza (2002, p. 78), "lamentavelmente, nunca houve ação governamental no sentido de esclarecer a população para a importância da preservação das florestas. Ao contrario, o então Instituto de Colonização e Reforma Agrária INCRA - e os correspondentes nos estados condicionavam a expedição de títulos de domínio em terras públicas à comprovação do desmatamento das áreas ocupadas. (...) $\mathrm{Na}$ verdade, na maior parte do Brasil, as autoridades não têm tomado nenhuma providência para recuperar ou manter as áreas de reserva legal. (...) Dessa forma a atuação da sociedade civil na sensibilização de proprietários de médias e grandes áreas de reserva legal para convertê-las em RPPNs resultaria em um incremento considerável na proteção de terras privadas e no aumento das unidades de conservação sob a responsabilidade de particulares".

Por essa e outras razões, a expansão das áreas protegidas pela iniciativa privada é atualmente considerada essencial, motivo pelo qual vários países têm facilitado a criação de reservas desse tipo (MORSELLO \& MANTOVANI, 1997).

A primeira iniciativa privada de instituição de área de preservação ambiental através de áreas de conservação ${ }^{9}$ data do final século XIX, quando surgiu na Inglaterra o conceito de Reserva da Natureza. Naquela época foi formado o grupo chamado Nacional Trust, que, por meio de contribuições, adquiriu, em 1899, a primeira reserva particular na Inglaterra - a Wicken Fen, com o objetivo de

\footnotetext{
9 Por "áreas de conservação" entende-se as áreas naturais para as quais haja algum tipo de legislação, estabelecendo medidas de proteção. 
preservar um certo grupo de plantas (DUFFEY, 1990, citado por MORSELLO \& MANTOVANI, 1997).

Apesar da contemporaneidade com o PN de Yellowstone, o modelo de áreas protegidas públicas se firmou como política mundial de conservação ambiental. Somente nos últimos anos é que essa situação vem se alterando e, em muitos países, várias iniciativas privadas para a instituição de reservas particulares vêm sendo tomadas. Um dos fatos que mais contribuem para isso é a constatação da dificuldade do setor público para, sozinho, garantir a conservação do meio ambiente e, conseqüentemente, da necessidade da sociedade civil se engajar nessa missão.

Vários países, inclusive da América Latina, possuem reservas privadas criadas a partir da iniciativa de seus proprietários e de organizações nãogovernamentais. Na África do Sul, o programa de reservas particulares, National Heritage Program, é totalmente voluntário, não envolvendo nenhuma forma de legalização de área ou incentivo econômico. Na Inglaterra, além das iniciativas voluntárias, o governo possui linhas de financiamento especiais para projetos de estabelecimento de reservas privadas, quando estas permitem o uso público (Country Parks). A intenção, nesses casos, é reduzir a pressão de visitação sobre áreas mais importantes. (BROTHERTON, 1975, citado por MORSELLO \& MANTOVANI, 1997)

Outro exemplo de sucesso na implementação de áreas de preservação privadas é o que acontece nos Estados Unidos, onde um grande número de organizações denominado de "Land Trust" se dedica à proteção de terras privadas. Elas tiveram início em 1950 e após um crescimento exponencial chegou em 1998 com 1.200 organizações dedicadas à proteção de terras privadas por meio da utilização de ferramentas de conservação privada tais como a servidão ecológica e as reservas naturais (WIEDMANN, 1997; PISKULICH, 2001).

$\mathrm{Na}$ Costa Rica as reservas privadas são absolutamente voluntárias e não são inscritas em nenhum registro do governo, não fazendo parte do sistema governamental. Contudo recebem incentivos, que se caracterizam como pagamento direto aos proprietários pela conservação de sua propriedade. A idéia é de que a propriedade que se mantém em estado natural produz muitos serviços ambientais, 
como: proteção das bacias hidrográficas, produção de oxigênio etc. Nesse país existe um fundo que recebe dinheiro dos programas de fixação de carbono em desenvolvimento. Cada ano se estabelece quais são as áreas prioritárias de conservação e os proprietários, com terras nessa área, que quiseram estabelecer limitações de uso para suas terras, recebem aproximadamente 500 dólares por hectare, por ano, durante cinco anos (PISKULICH, 2001).

$\mathrm{Na}$ França, desde 1976, as chamadas reservas voluntárias recebem a mesma proteção e possuem as mesmas restrições de uso que os santuários oficiais. Ao contrário do Brasil, essas reservas são estabelecidas por tempo limitado, 6 anos, e podem ser abolidas a qualquer momento a pedido do proprietário ou pela infração das regras preestabelecidas. Na Bélgica, as reservas voluntárias possuem as mesmas regras que as áreas protegidas governamentais e são reconhecidas por 10 anos com renovação automática (IBAMA / FUNBIO, s/d).

$\mathrm{Na}$ Colômbia, as "Reservas Naturales de la Sociedad Civil" são temporárias e o proprietário pode romper o termo de compromisso com o órgão ambiental, abolindo sua reserva se esse órgão não cumprir suas obrigações, e não há necessidade de comprovação de propriedade da área, pois outras formas de posse são aceitas (IDEM, s/d).

No Brasil, a história das áreas protegidas sob domínio privado tem início em 1934 através do antigo Código Florestal, que previa o estabelecimento de áreas particulares protegidas por meio das "Florestas Protetoras". Essas florestas permaneciam de posse e domínio do proprietário e eram inalienáveis. Contudo, em 1965, com a instituição do novo Código Florestal, a categoria de "Florestas Protetoras" foi extinta, mas ainda permaneceu a possibilidade do proprietário da floresta não preservada ${ }^{10}$ gravá-la com perpetuidade baseado no artigo $6^{\circ}$ da Lei 4.711/65 - Código Florestal.

Em 1977, o Instituto Brasileiro de Desenvolvimento Florestal (IBDF) baixou a Portaria $n^{\circ}$ 327-P definindo e normatizando os Refúgios de Animais Nativos. Esta Portaria surgiu em decorrência da reivindicação de alguns proprietários rurais do

$10 \mathrm{Na}$ lei florestal, "floresta não preservada" significa a propriedade que pode ser usada economicamente com as limitações legais de todas as propriedades, ou seja, mediante licença pode ser desmatada, manejada ou ter uso extrativista. $\mathrm{O}$ artigo $6^{\circ}$ da lei $\mathrm{n}^{\circ} 4.771$ diz que, se o proprietário quiser, estes usos diretos podem ser eliminados. (WIEDMAN, 1997, p7) 
estado do Rio Grande do Sul que não queriam a caça em suas propriedades (WIEDMAN, 1997).

Em 1988, a idéia de Refúgio de Animais Nativos evoluiu, estendendo-se também à proteção da vegetação com a criação, através da Portaria $n^{\circ} 217$, das Reservas Particulares da Fauna e Flora.

Finalmente, através do Decreto Federal $n^{\circ} 98.914$ de 31 de janeiro de 1990 ficou instituída, já sob a gerência do Instituto Brasileiro do Meio Ambiente e dos Recursos Naturais Renováveis - IBAMA, a Reserva Particular do Patrimônio Natural - RPPN, que regulamentou o artigo $6^{\circ}$ do Código Florestal de 1965 - base da legislação sobre reservas particulares.

A idéia foi ampliar o conceito das Reservas Particulares de Fauna e Flora, dando-lhes um regulamento mais seguro, com garantia de perenidade e incentivos à sua criação mediante a isenção de impostos e prioridade em financiamentos de projetos ambientais (WIEDMAN, 1997). Posteriormente esse decreto foi atualizado pelo Decreto nº 1.992 de 5 de junho de 1996.

Mas foi somente em 2000 que as RPPNs conquistaram o status de Unidades de Conservação, com a aprovação da Lei do SNUC, fazendo do Brasil o único país da América Latina a incluir as reservas privadas no seu sistema de áreas protegidas oficial (MESQUITA \& LEOPOLDINO, 2002).

O texto que trata das RPPNs está no Artigo 21 do SNUC. Entretanto, até o presente momento, as normas em vigor são as presentes nos decretos anteriores, pois o Art. 21 do SNUC ainda não foi regulamentado. As normas que irão finalmente regulamentar este artigo estão atualmente em estudo na procuradoria do IBAMA.

Como pode ser observado no gráfico abaixo, o decreto de 1996 deu grande estimulo à criação de RPPNs, incrementando o número de unidades criadas por ano. Contudo esse número caiu bastante em 2002 e neste ano os processos para criação de novas unidades ainda estão parados. Um dos principais motivos é a falta de regulamentação mais detalhada. 
Figura 1. Criação de RPPNs por ano

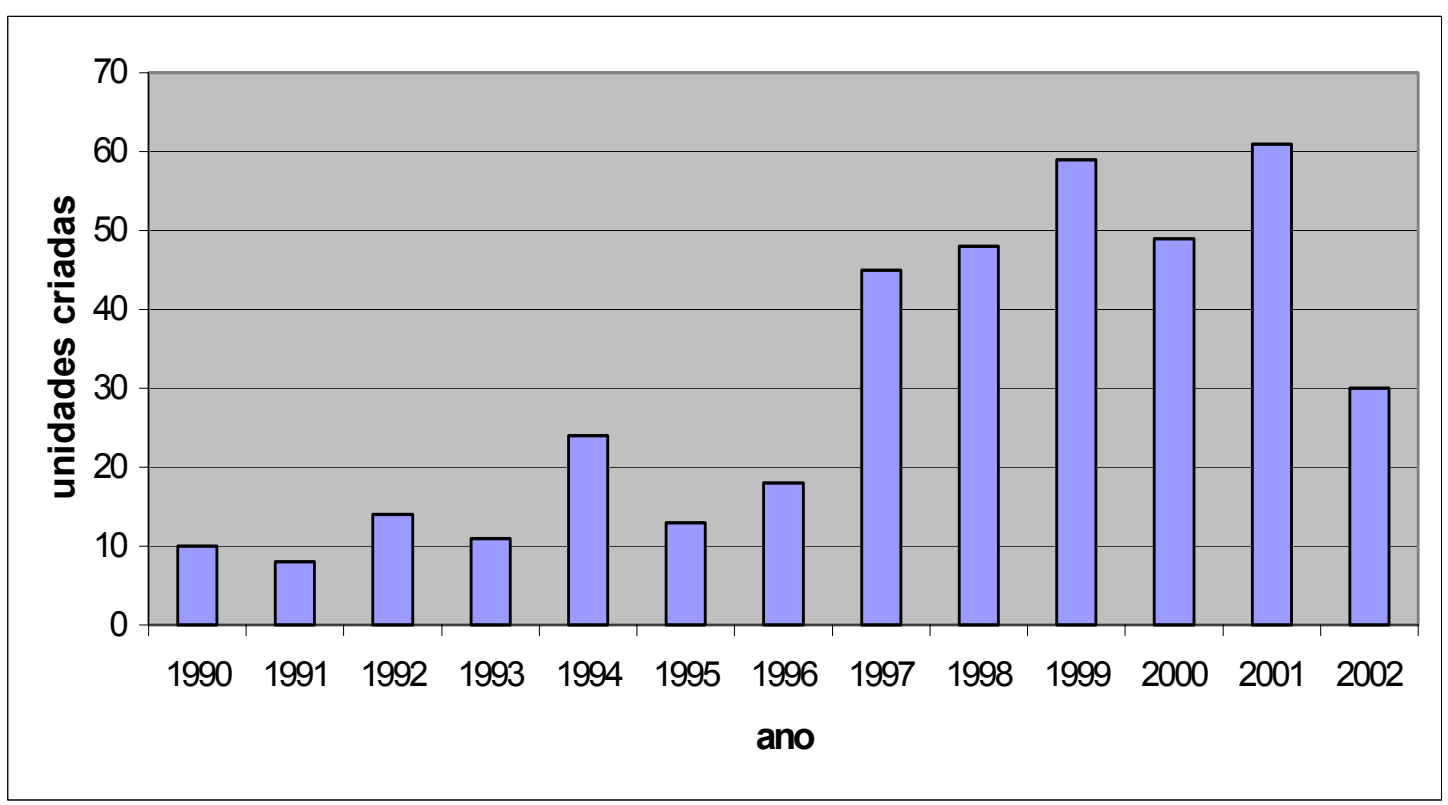

Fonte: DIREC/IBAMA, 2003

As RPPNs, apesar de enquadradas na categoria de Uso Sustentável, se configuram na mesma lei como Unidade de Conservação de Proteção Integral, face ao veto presidencial no item III do parágrafo 2 do artigo 21 , que previa a utilização direta de recursos naturais nas RPPNs (TORRECILHA \& LOUREIRO, 2000).

A instituição de uma RPPN é ato de vontade expresso pelo proprietário da terra, sem acarretar na perda do direito de propriedade. O objetivo da RPPN é a proteção dos recursos ambientais representativos da região, nela são admitidas apenas atividades de cunho científico, cultural, educacional, recreativo e de lazer.

Os resultados desses doze anos de implantação revelam como as RPPNs podem se tornar um instrumento fundamental para a conservação dos ecossistemas. Entre 1990 e 2002, foram 390 RPPNs reconhecidas pelo IBAMA em instância federal ${ }^{11}$ para a conservação de, aproximadamente, 544.827 hectares dos diversos biomas.

As maiores RPPNs até agora registradas no IBAMA são a Seringal Novo Destino, no Amazonas, com 104 mil hectares e as duas Estâncias Ecológicas SESC Pantanal, no Mato Grosso, com 87.871,44 hectares; e, as menores são a

\footnotetext{
${ }^{11}$ Se forem consideradas as unidades instituídas em nível estadual, os valores chegam a mais de 500 RPPNs e mais de 600 mil hectares (PEREIRA, 2002). 
Chakra Grisu, no DF, com 1 (um) hectare e a RPPN Cabanos, de 0,60 hectare. Os estados com os maiores números de RPPNs criadas, em nível federal, são Minas Gerais (62), Bahia (50) e Goiás (42).

Nota-se, assim, que as Áreas Particulares Protegidas deram um significativo impulso nas iniciativas de conservação do país. As Reservas Particulares do Patrimônio Natural (RPPNs) representam um importante passo para envolver direta e voluntariamente a sociedade civil brasileira na conservação da biodiversidade. Por intermédio desse mecanismo, a iniciativa privada pode dar a sua contribuição à proteção do meio ambiente e aumentar significativamente a possibilidade de se obter um cenário efetivo de áreas protegidas. O maior exemplo disso pode ser observado no bioma Pantanal, que, por meio dessa iniciativa, consegui ter sua área de conservação ambiental, que era de 0,57\%, ampliada para 2,14\% do bioma (IBAMA, 2003a).

Tabela 1. Reservas Particulares do Patrimônio Natural por bioma

\begin{tabular}{lc}
\hline \multicolumn{1}{c}{ Bioma } & Quantidade de Reservas \\
\hline Caatinga & 33 \\
Campos de altitude & 2 \\
Campos do Sul / Mata Atlântica & 10 \\
Cerrado & 101 \\
Floresta Amazônica & 38 \\
Mangue / Mata Atlântica & 2 \\
Mata Araucária & 9 \\
Mata Atlântica & 176 \\
Pantanal & 13 \\
Restinga/ Mata Atlântica & 6 \\
\hline Fonte: DIREC/IBAMA, 2003 &
\end{tabular}

Além da própria conservação, as RPPNs podem trazer vários outros benefícios para o meio ambiente e para a população. Um dos principais benefícios, e objetivos, das RPPNs se refere ao esforço de implementação de corredores ecológicos. Apesar de serem um eficiente instrumento de conservação da natureza, os espaços protegidos ressentem-se da tendência mundial: transformarem-se em "ilhas" de ecossistemas conservados num "mar" de degradação. Os corredores ecológicos apresentam-se como mecanismo com probabilidades de mitigar os eventuais impactos que a insularização pode ocasionar na biodiversidade das 
Reservas a médio e longo prazo (IBAMA / FUNBIO, s/d).

Nesse sentido, as RPPNs, mesmo que em sua absoluta maioria constituídas de fragmentos florestais, têm grande importância, principalmente se articuladas com outros espaços especialmente protegidos, notadamente de domínio público, compondo de forma complementar o Sistema de Unidades de Conservação (TORRECILHA \& LOUREIRO, 2000).

A conservação de populações endêmicas também é outra função das RPPNs, visto se caracterizarem como depositárias de biodiversidade. Algumas espécies devem sua sobrevivência e mesmo sua recuperação às áreas de conservação, ainda que em pequenas "ilhas". A recuperação das populações de mico-leão-dourado, por exemplo, só é possível por meio a aliança entre a Reserva Biológica Poço das Antas, no Estado do Rio de Janeiro e as RPPNs que estão em seu entorno ${ }^{12}$ (FERNANDES et al, 2000).

Outro papel que as RPPNs podem exercer está ligado à disseminação do conhecimento sobre os biomas brasileiros, visto que estimula a aproximação com o meio ambiente e a sensibilização quanto à importância dos ecossistemas existentes na natureza. Fernandes et all (2000), afirmam que a possibilidade de desenvolvimento associado à manutenção de remanescentes de mata, por meio de atividades ambientalmente sustentáveis como o Ecoturismo, tem contribuído com a divulgação e a conservação de fragmentos da Mata Atlântica, sob forma de RPPN. O mesmo pode ocorrer com o Cerrado, já que, na prática, é um dos biomas menos conhecidos e valorizados pela população. Dessa forma, Torrecilha \& Loureiro (2000) defendem que as RPPNs têm valor do ponto de vista da criação de condições à realização de ações de educação ambiental, tendo como carro chefe o turismo ecológico

Assim, no que diz respeito ao Ecoturismo, as RPPNs situam-se como locais próprios para a prática desta atividade, multiplicando quantitativa e qualitativamente os espaços naturais potenciais para o Ecoturismo, visto se tratar de locais de grande valor ecológico. Além disso, dado ao caráter privado e às dimensões das RPPNs (em geral, bem menores que os Parques, por exemplo), fatores como infra-estrutura adequada, recursos humanos qualificados e gestão

\footnotetext{
${ }^{12}$ Para viabilizar a sobrevivência da espécie é preciso somar aos 6 mil hectares da REBIO Poço das Antas, mais 16 mil hectares sob a forma de RPPN. Até agora apenas $16,68 \%$ do objetivo foi atingido. 
eficiente para a atividade são mais viáveis, visto que não passam pelos entraves burocráticos existentes em outras Unidades de Conservação públicas.

Em vários Estados brasileiros já existem casos de RPPNs onde o Ecoturismo tem dado certo. A RPPN Alto da Boa Vista, em Minas Gerais, é um exemplo. A reserva ocupa uma área total de 138,26 ha, sendo 96,00ha de floresta nativa, remanescente da Mata Atlântica, e mais 42,00ha destinados ao reflorestamento e produção agrícola alternativa. O Ecoturismo representa a principal atividade da RPPN que oferece, além de transporte e assistência pessoal, casas para pousada, área de camping e lazer (cachoeiras e quadra poliesportiva), guia para a prática do trekking e rádio - comunicação. Também são desenvolvidas atividades de educação ambiental. (COSTA, 2001)

Outro exemplo é a RPPN Bom Retiro no Estado do Rio de Janeiro. A reserva possui área de 472 hectares de Mata Atlântica e mudou totalmente a principal atividade econômica da propriedade, que passou da pecuária para o Ecoturismo, contando com o apoio técnico da Associação Mico-Leão-Dourado. A reserva recebe centenas de visitantes todos os anos, oferecendo serviço de hospedagem, alimentação e passeios por trilhas educativas com guias locais. Atualmente a propriedade vem se mantendo por meio dessa atividade (FERNANDES et al, 2000).

No entorno de Brasília, o melhor exemplo que temos, graças ao seu grau de implementação, é o Santuário de Vida Silvestre Vagafogo, que já desenvolve o Ecoturismo a mais de 10 anos. Nessa propriedade ocorre o casamento entre a fazenda de produtos orgânicos e a RPPN, onde parte da fazenda fica preservada. No local existe centro de visitantes, trilhas auto-guiadas e refeições. Esses serviços têm trazido cerca de 10 mil visitantes por ano, nos dois últimos anos, garantindo a viabilidade da área (PÁDUA, 1996; CAIUT, 2002). 


\section{Material e Métodos}

\subsection{Santuárìo de Vida Silvestre Vagafogo}

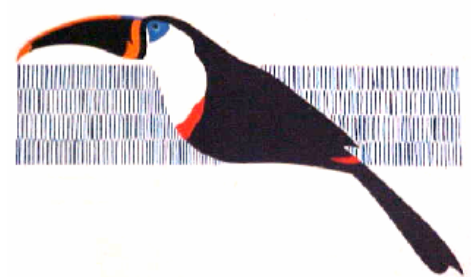

A escolha do Santuário de Vida Silvestre Vagafogo se deu por uma conjunção de fatores, tais como: a participação em algumas reuniões de proprietários de RPPNs, principalmente de Goiás e do DF, onde foi possível verificar o contexto das RPPNs na região; o conhecimento particular da autora sobre a reserva, aliado à localização e outras facilidades pessoais; e, principalmente, por ser uma RPPN que vem desenvolvendo o ecoturismo há vários anos.

\section{Histórico}

A Fazenda Vagafogo está situada no município de Pirenópolis, cidade histórica do estado de Goiás. Foi adquirida por seus atuais proprietários, Evandro Engel Ayer e Catarina J. Schiffer, em 1975 com o objetivo de morarem na fazenda e terem uma vida mais saudável. Começaram a morar definitivamente na fazenda em 1980 e, desde o começo, perceberam a riqueza da natureza no local e passaram a preservar a mata e parte do cerrado da propriedade.

No início, chegaram a lidar com lavoura tradicional em parte da fazenda, mas as condições do solo e o ataque dos animais selvagens inviabilizaram a plantação. Na busca por novos meios de subsistência para a família e a própria fazenda e a partir da produção do pomar tiveram a idéia de verticalizar a produção, agregando valor aos produtos e transformando-os em geléias e outros artigos naturais para vender diretamente em Brasília, já que Pirenópolis ainda não oferecia mercado para os seus produtos.

Durante esse período, a abertura de trilhas dentro da floresta levou ao melhor conhecimento da área e à possibilidade de lazer às margens do rio Vagafogo, que passou a ser um atrativo tanto para a família como para 
amigos. No final dos anos 1980 começaram, então, a receber visitantes que estavam hospedados em Pirenópolis e grupos de estrangeiros que demandavam por um local agradável onde pudessem fazer caminhadas em contato com a natureza.

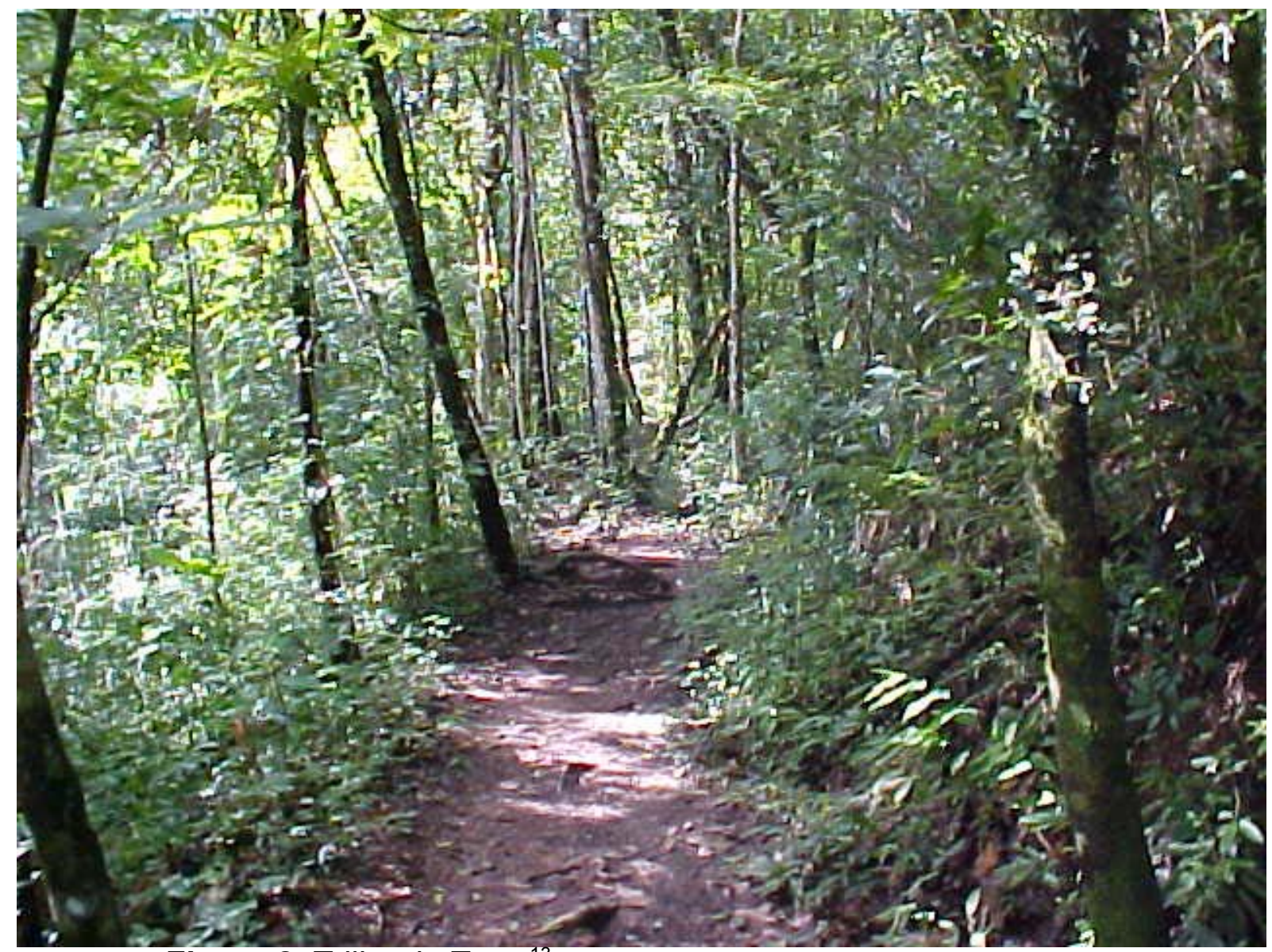

Figura 2. Trilha de Terra ${ }^{13}$

Diante da possibilidade de seu "mercado consumidor" se deslocar para Pirenópolis e pressionados pelo crescente turismo da cidade, decidiram buscar parcerias com ONG's para confirmar a aptidão e o potencial da área para receber visitação. Começava aí a parceria com a FUNATURA - Fundação Pró-Natureza, por meio do Projeto Santuário de Vida Silvestre. Em 1990 foi assinado um contrato de cooperação mútua com a FUNATURA, onde a fazenda se obrigava a preservar uma parcela de sua área e a ONG em contrapartida daria o apoio necessário para a criação do Santuário e para a implementação da atividade ecoturística.

Assim, dos 46 hectares da propriedade, 17,76 hectares foram transformados em Santuário de Vida Silvestre - SVS e, posteriormente, em Reserva Particular do Patrimônio Natural - RPPN (Decreto 924/90). A partir disso a

\footnotetext{
${ }^{13}$ Todas as fotos foram gentilmente cedidas pela ONG NATIVA de Goiânia. 
FUNATURA passou a buscar financiamento para a elaboração do Plano de Manejo e para a construção e implementação do Centro de visitantes

Para a execução do Plano de Manejo, a FUNATURA contou com o apoio financeiro da WWF - o Fundo Mundial para a Natureza, no valor de US\$10.000,00. O Centro de Visitantes foi construído com recursos doados pela Embaixada Britânica no Brasil no total de US\$27.000,00 e depois implementado com recursos da Fundação O Boticário de Proteção à Natureza (mais US\$12.000,00). Em 19 de março de 1992 foi inaugurado o centro de visitantes, com a presença do Príncipe Phillip da Inglaterra, e aberta, oficialmente, a propriedade para a visitação.

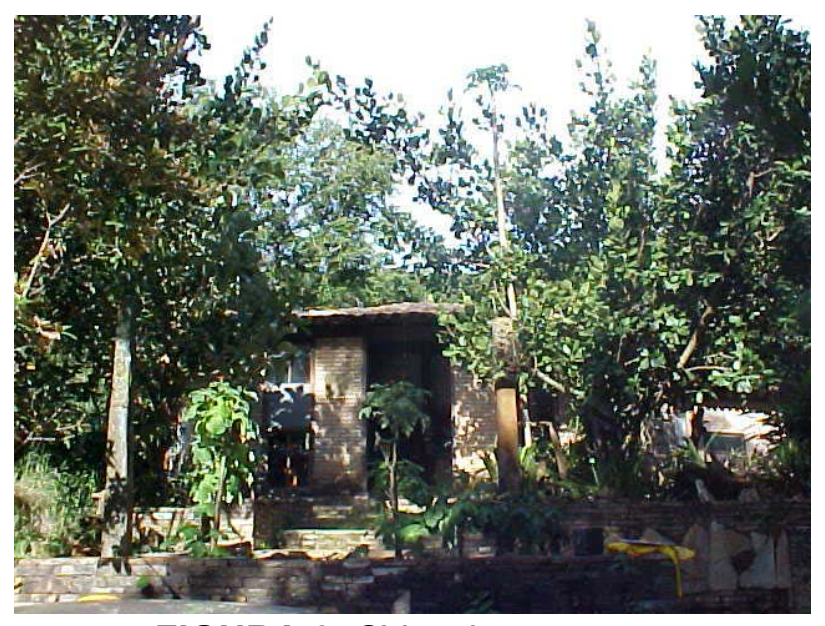

FIGURA 3. CV - vista externa

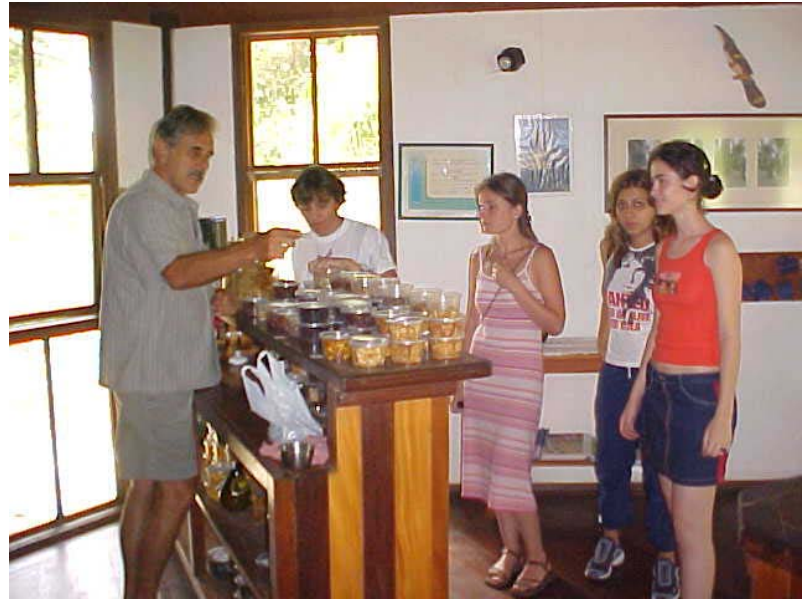

FIGURA 4. CV - parcial interna

Nos primeiros anos de atividade houve outro projeto financiado pela Fundação O Boticário que tinha como objetivo manter um Biólogo na fazenda para desenvolver trabalhos de Educação Ambiental com as escolas da cidade. Apesar do projeto não ter dado certo, devido à falta de interesse das professoras, a permanência desse biólogo foi muito importante para o desenvolver dos projetos de educação ambiental que estão, hoje, em andamento.

O Santuário oferece basicamente quatro serviços: caminhadas em trilha interpretativa e banho no rio Vagafogo; atividade de educação ambiental para grupos; brunch - um café-da-manhã prolongado com produtos naturais, em sua maioria característicos do cerrado; e a venda de produtos elaborados na própria fazenda com a garantia de serem feitos a partir da agricultura orgânica.

Atualmente a reserva conta também com um fundo chamado "Fundo Vagafogo de Educação Ambiental", onde 10\% dos ingressos são destinados ao 
fundo com o objetivo de apoiar projetos das escolas públicas do município ligados à Educação Ambiental.

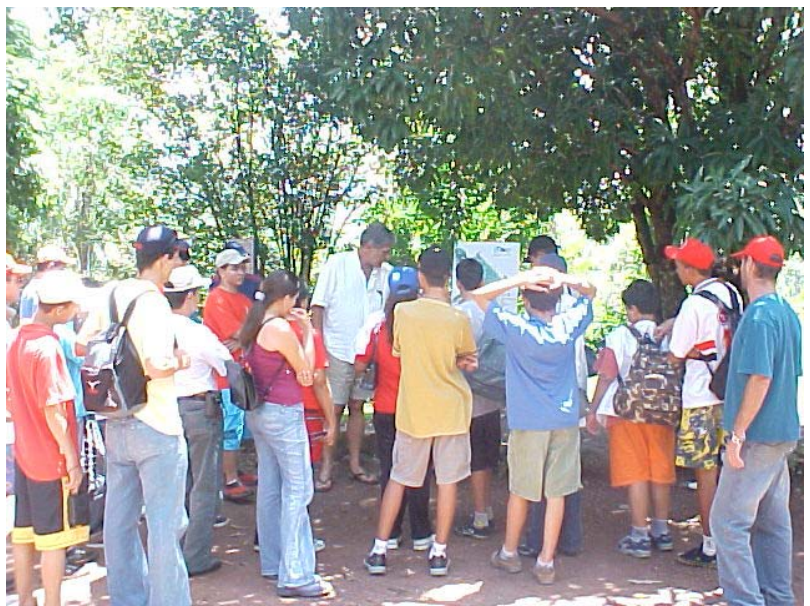

FIGURA 5. Grupo de Educação Ambiental

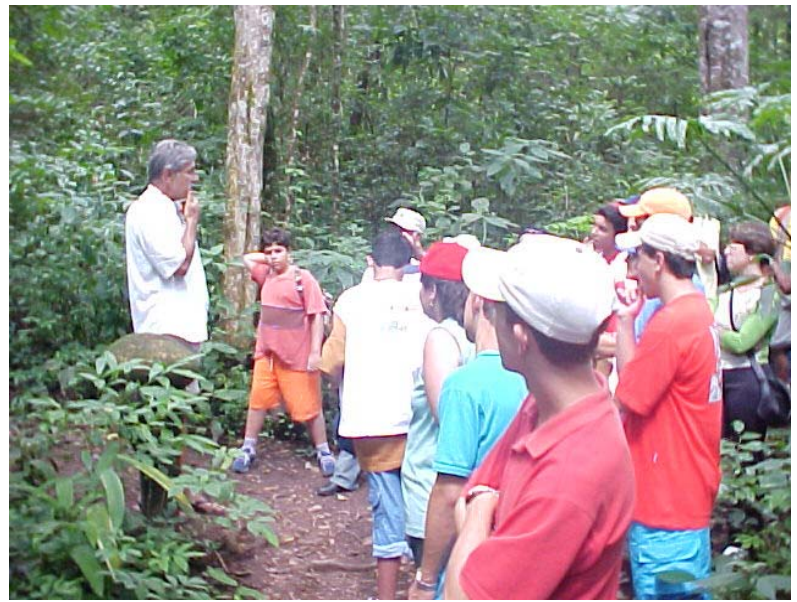

FIGURA 6. Grupo de EA na trilha

Para a comemoração dos 10 anos de atividades, foi feita, com o apoio da FUNATURA e o financiamento da Embaixada Britânica no Brasil (US\$ 30 mil para a construção da passarela e da base da torre de observação), a revitalização da trilha a partir da implantação da trilha suspensa feita com madeira apreendida e doada pelo Instituto Brasileiro de Meio Ambiente e Recursos Naturais Renováveis - IBAMA.

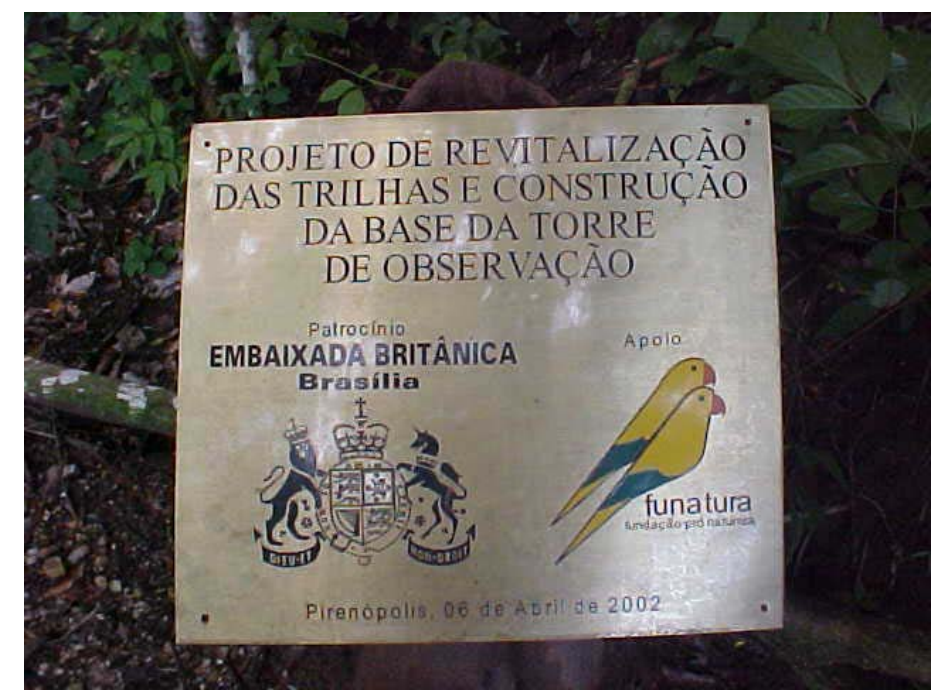

FIGURA 7. Placa de re-inauguração da trilha

Neste ano, o Santuário de Vida Silvestre Vagafogo está completando onze anos de atividade e já possui nova estrutura para melhor acolher os grupos escolares que vão para a reserva participar de atividades de Educação Ambiental. 


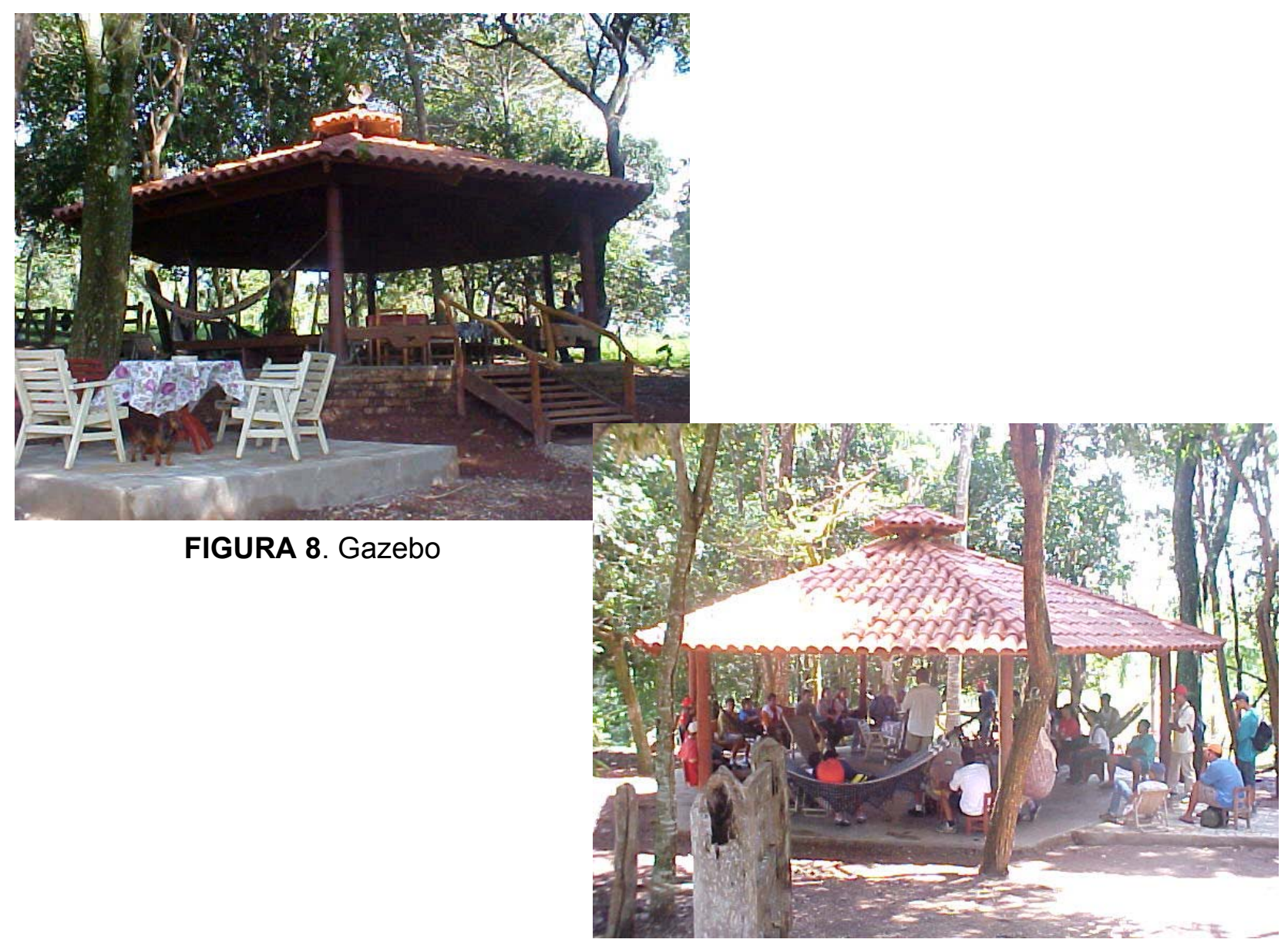

FIGURA 9: E.A. no Gazebo

De acordo com a classificação criada por Mesquita (1999) para as reservas privadas na América Latina, o Santuário de Vida Silvestre Vagafogo pode ser considerado como um Parque Ecoturístico. Essa categoria se caracteriza por:

"possuir área menor que mil hectares e adotar estratégias de manejo (gestão) muito focada no turismo e na recreação. Podem ter atividades agrícolas, mas em pequena escala e somente para o consumo interno, as facilidades para a visitação e interpretação ambiental são constantes nas reservas desta categoria, que também contemplam o turismo rural. Estão abertos à educação ambiental e à investigação. Pelo menos $30 \%$ da receita é gerada pelo turismo e atividades afins. As demais atividades geram menos de uns $10 \%$ da receita total, cada um." (MESQUITA, 1999, p. 45) ${ }^{14}$

\footnotetext{
${ }^{14}$ Tradução livre da autora.
} 


\section{Características Biofísicas ${ }^{15}$}

\section{a) Geomorfologia}

Dentro do perímetro da fazenda pode-se identificar a subcompartimentação do relevo da Serra dos Pireneus: o morro do Frota, de expressão regional, e o alargamento do vale do rio Vagafogo. Fazem parte da área da reserva o topo do morro e a encosta.

A região do Planalto Goiano que em sua porção oeste localiza-se o Planalto do Alto Tocantins/Paranaíba, divisor de águas dos rios que the dão nome. Neste Planalto a Serra Dourada e o seu prolongamento, a Serra dos Pireneus em uma das depressões intermontanas da serra dos Pireneus estão o vale do rio Vagafogo e o morro do Frota. Nessa região, onde há o alargamento do vale do rio Vagafogo está localizada a Fazenda Vagafogo.

\section{b) Clima}

O clima é quente e semi-úmido, caracterizado por apresentar temperaturas médias anuais entre $19^{\circ}$ e $26^{\circ}$ e pluviosidade médias em torno dos $1.500 \mathrm{~mm}$ anuais. Com temperaturas elevadas sobretudo na primavera e no verão e chuvas concentradas nos semestre do verão, notadamente, dezembro, janeiro e fevereiro. $O$ inverno é estação de temperaturas amenas com insuficiência de chuvas e conseqüente déficit hídrico nos solos. O excesso de chuva do verão garante importantes lençóis de água subterrânea que subsistem mesmo durante as secas, garantindo a perenidade dos rios mais significativos do centro-oeste.

\section{c) Hidrografia}

O rio das Almas, que atravessa a cidade de Pirenópolis nasce na Serra dos Pireneus em sua vertente sul, seguindo em direção leste-oeste e depois para o noroeste e finalmente para o nordeste, e segue para o nordeste até se unir ao rio

\footnotetext{
${ }^{15}$ As informações sobre as características biofísicas da Fazenda Vagafogo foram extraídas do Plano de Manejo da fazenda, elaborado pela Fundação Pró-Natureza - FUNATURA (1990). 
Maranhão . Aproximadamente $5 \mathrm{~km}$ depois de atravessar a cidade o rio das Almas recebe as águas do rio Vagafogo pela sua margem direita. Este rio nasce na vertente norte do morro do Frota, corre no sentido leste-oeste e depois vira bruscamente para o sul, mantendo essa direção até desaguar no rio das almas. 0 SVS da Fazenda Vagafogo situa-se à margem esquerda desse rio, justamente no ponto de sua mudança de curso para o sul.

\section{d) Solos}

A classe de solos dominante na Fazenda Vagafogo é o Latossolo Vermelho-Amarelo. Já na mata ciliar ocorre, ao longo do rio, trecho de solos mais profundos e argilosos. Essa cobertura vegetal, densa e com raízes profundas, representa relevante papel na estabilização dos solos e dos materiais mais grosseiros transportados dos pontos mais altos da encosta, pois impede os deslizamentos do terreno em direção ao leito do rio.

Há ainda pequenos trechos de solos hidromórficos junto ao leito do rio, inclusive em sua parte mais plana, localmente denominada brejos.

\section{e) Vegetação}

O SVS Vagafogo localiza-se na região dos cerrados. A reserva protege uma área predominantemente coberta por vegetação de mata ciliar, que se estende pela encosta do morro do Frota até o rio Vagafogo. O restante da área, correspondente ao topo do morro é ocupado por vegetação de cerrado. Existe ainda uma segunda mancha de cerrado que, embora esteja situada fora da área gravada como reserva também será preservada e utilizada para a interpretação e educação ambiental.

A mata ciliar da fazenda caracteriza-se como de terra firme ou seca. Nesta é observado o estrato arbóreo superior que alcança cerca de $25 \mathrm{~m}$ de altura, composto por arvores de fuste reto; o estrato inferior de 6 a 15m; outro arbustivo com até $3 \mathrm{~m}$ e estrato rasteiro constituído por plantas herbáceas. A umidade geral do ambiente, favorecida pela natureza fechada da mata, propicia a proliferação de epífitas como bromeliáceas, cactáceas, orquidáceas, peperômias, samambaias, 
avencas, musgos, liquens e orelhas-de-pau. Além de diversas umbrófilas terrestres, há também grande quantidade de cipós e trepadeiras. A flora da mata ciliar é bastante rica. Dentre as espécies arbóreas de maior porte, as que mais se destacam são os jatobás, o jequitibá-rosa, a garapa, o angico e o pau-d’óleo

No cerrado que ocorre na parte mediana da fazenda pode-se observar dois estratos de vegetação: um arborescente que atinge de 2 a 6 metros e outro formado por subarbustos e diversas ervas. A flora do cerrado também é bastante diversificada. A espécies mais comuns são o pequi, o araticum, o pau-terra, a sucupira-roxa, o jacarandá-do-cerrado e o cajuí. No topo do morro ocorre o campo cerrado com a incidência de espécies como o murici, o jatobá-do-cerrado, o cabelode-negro, o bate-caixa e o pau-terra-de-folha-larga.

\section{f) Fauna}

As matas de galeria são de extrema importância para as espécies que freqüentam o cerrado, servindo de abrigo e fonte de alimento e água para estes animais, principalmente na estação de seca. Dentre os animais observados, os macacos e morcegos são os mais fáceis de encontrar. Existe um grupo de 10 a 15 indivíduos de macaco-prego em parte da mata e outro de cerca de cinco indivíduos, no outro extremo. Existe também um grupo de mico-estrela e um pequeno grupo de bugios.

Foram encontrados sinais de tatu-galinha, tatu-mulita, tatu-peba e tamanduá-mirim. E também de cachorro-do-mato, papamel, quati, preá, cutia, cuícas e cobras, muitas delas venenosas, como a cascavel, a jararaca, a cobra-coralverdadeira etc.

$\mathrm{Na}$ fazenda Vagafogo, a maior significância encontra-se no grupo das aves. Foram encontradas espécies tanto da Amazônia (beija-flor, bico-de-brasa e trinca-ferro), como do sudeste brasileiro (Benedito) e da caatinga (cã-cã). Foram encontradas sete espécies de pica-paus e também uma subespécie de tucano (Ramphastos culminatus pintoi) que teve sua especiação na Serra Dourada, Goiás.

No total, durante o levantamento de espécies para a elaboração do Plano de Manejo, foram catalogadas 72 espécies. Atualmente já existem mais de 160 
espécies catalogadas encontradas nos limites da reserva, indicando que é área bastante rica e que vem mantendo seu equilíbrio natural durante esses anos.

\section{Zoneamento}

No Plano de Manejo foram definidas para a Fazenda Vagafogo oito zonas diferentes, sendo cinco dentro da área de conservação e três no restante da fazenda, como pode ser visto nos mapas que seguem. Cada uma das zonas definidas tem um objetivo específico.

Dentro do Santuário, o zoneamento acompanha a seguinte divisão:

- Zona de Proteção Integral: tem por objetivo a proteção integral dos recursos naturais e da biodiversidade, garantindo o processo evolucionário dos ecossistemas. Nessa área só é permitido a entrada humana com fim de fiscalizar ou fazer estudo científico. Corresponde a área mais central da área de conservação;

- Zona Primitiva: criada para proteger os ecossistemas naturais e a biodiversidade, ao mesmo tempo em que se promove a interpretação e educação ambiental. Pode haver o uso público de forma bastante limitada e sem a implantação de qualquer equipamento.é a maior zona dentro do santuário, englobando toda a área no entorno da zona de proteção integral e em volta e no interior da trilha Mãe da floresta;

- Zona de Recuperação: propõe-se a deter a degradação dos recursos naturais e/ou promover a recuperação da área. Corresponde à área de cerrado no alto do morro do Frota;

- Zona de Recreação e Lazer Extensivos: visa a manutenção do ambiente natural com pequeno impacto humano, oferecendo acesso e facilidades de uso público para fins educativos e recreativos. Corresponde à localização da trilha interpretativa Mãe da Floresta e ao primeiro segmento da trilha Morro do Frota. Comporta equipamentos simples e uso limitado do rio;

- Zona Histórico-Cultural: procura preservar sítios históricos ou arqueológicos 
e manifestações culturais, contribuindo, assim, para a memória histórica da região. Corresponde ao trecho que apresenta os vestígios das antigas lavras de ouro da época dos bandeirantes e do respectivo rego d'água usado na mineração. Inclui também os sinais de uma velha estrada que ligava Pirenópolis a cidade de Goiás em uma área externa a reserva.

A área adjacente mantém relação de interação e influência com o Santuário, e por esse motivo também teve sua área dividida em áreas, de modo a favorecer a manutenção do Santuário. Nesta área também está incluída a área que dá apoio a visitação.

As zonas estão divididas em:

- Zona de Recreação e Lazer Intensivo: tem em vista promover a educação ambiental e atividades culturais, recreativas, interpretativas e de lazer intensivas. É a área destinada a receber a infra-estrutura de apoio ao usuário, tais como o centro de visitação e área de descanso;

- Zona de Uso Especial: dispõe-se a centralizar as estruturas de atendimento dos diversos usos da área de modo a minimizar o impacto decorrente da sua implantação. Estão inseridas as residências dos proprietários e do funcionário da fazenda;

- Zona de Uso Direto: tem por fim desenvolver atividades de uso direto da terra, essenciais aos serviços de produção e manutenção da propriedade. Corresponde às áreas para a criação de animais, como galinheiro, área de pasto e pomar. 


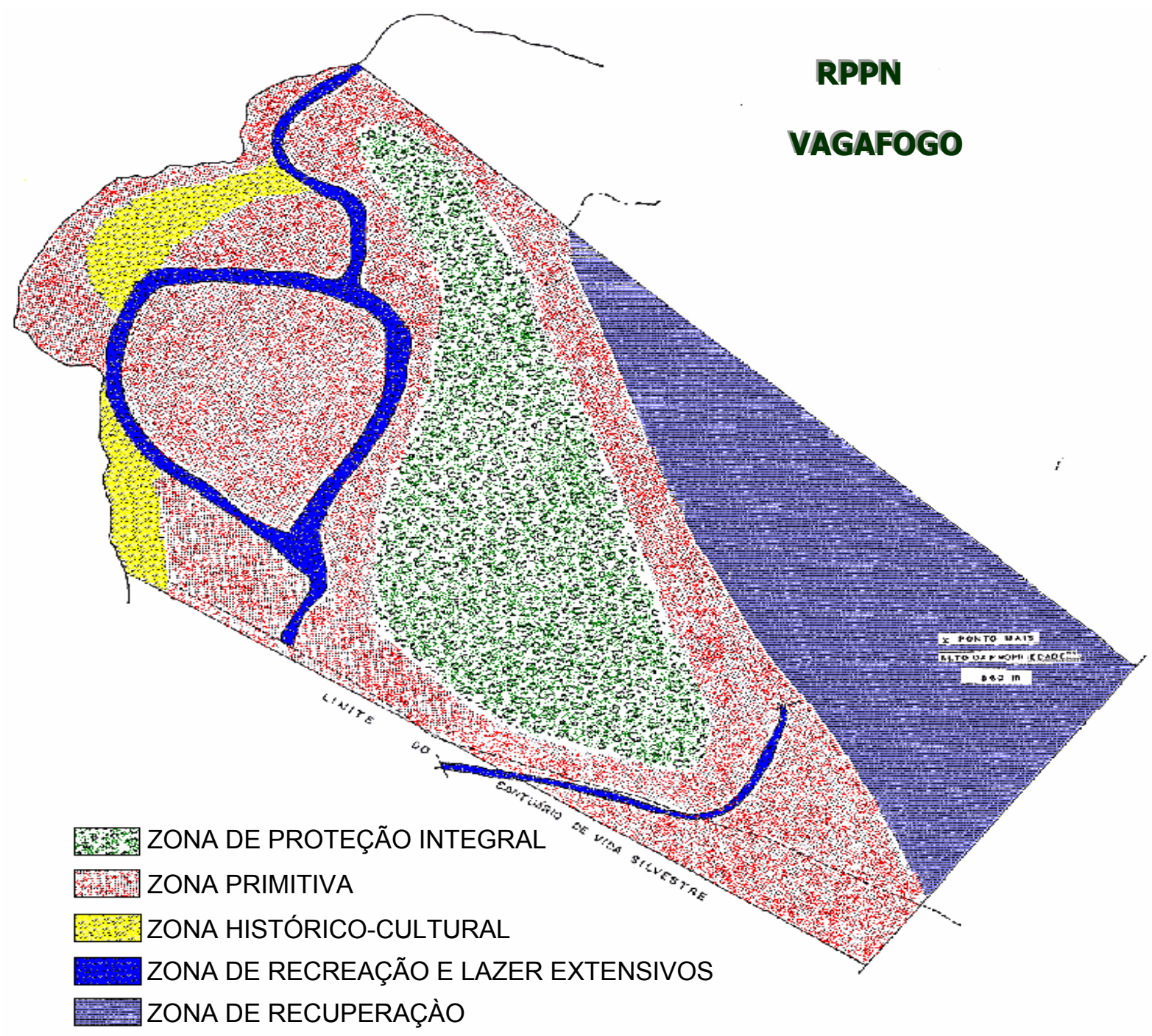

FIGURA 10. MAPA DO ZONEAMENTO DA RPPN VAGAFOGO 


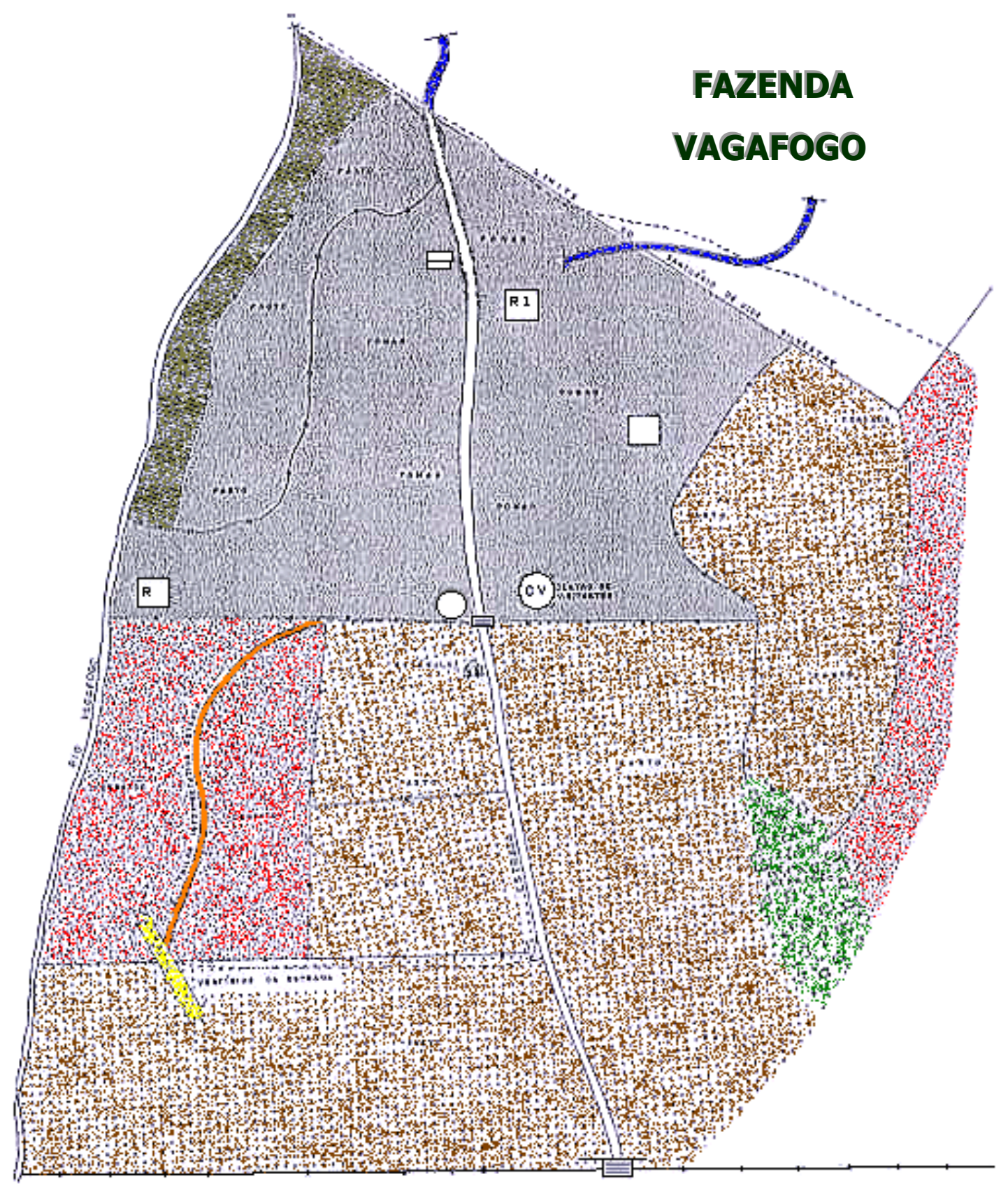

Fi: ZONA PRIMITIVA

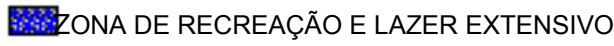
ZZONA HISTÓRICO - CULTURAL

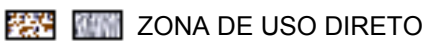

$\rightarrow$ CERCA

国 MATA BURRO

○ ORQUIDÁRIO
( ZONA DE RECREAÇÃO E LAZER INTENSIVO

(C) CENTRO DE VISITANTES

(G) GAZEBO

ZONA DE USO ESPECIAL

RT1 RESIDÊNCIA DO PROPRIETÁRIO

[R2] $2^{\mathrm{a}}$ RESIDÊNCIA

R3] RESIDÊNCIA DO PEÃO 


\section{Programas de Manejo}

A reserva possui três programas de manejo definidos, cada um englobando um conjunto de subprogramas que atendem a necessidade de manejo e conservação da área.

\section{a) Programa de Manejo do Meio Ambiente}

Conta com quatro subprogramas:

- de Proteção: proteger e conservar os recursos naturais e culturais da reserva;

- de Manejo de Recursos: normatizar o uso dos recursos naturais já em exploração a fim de evitar a degradação ambiental;

- de Investigação: possibilitar o desenvolvimento de investigação científica proporcionando um maior conhecimento dos recursos;

- de Monitoramento: monitorar tanto a evolução dos processos naturais dos ecossistemas protegidos como a evolução das atividades desenvolvidas na reserva.

\section{b) Programa de Uso Pứblico.}

Também inclui quatro subprogramas:

- de Recreação e Lazer: oferecer atividades de recreação e lazer de forma sustentável e em concordância com as aptidões da área;

- de Interpretação Ambiental: promover maior conscientização do usuário quanto ao meio ambiente, suas inter-relações e a importância da conservação da natureza por meio de interpretação dos recursos naturais e culturais da área;

- de Educação Ambiental: conscientizar o usuário da responsabilidade de cada pessoas na conservação dos recursos naturais e culturais do 
ambiente que os cerca;

- de Relações Públicas: divulgar o Projeto santuário de Vida Silvestre da FUNATURA, tendo a Vagafogo como primeiro santuário implantado, assim como seu Plano de Manejo. Captar recursos para a reserva.

\section{c) Programa de Operaçőes}

Estão inclusos dois subprogramas:

- de Administração: oferecer condições a implementação do Plano de Manejo e seus subprogramas;

- de Manutenção: zela pela integridade e funcionalidade da reserva.

\section{Capacídade de carga}

A definição da capacidade de carga que existe atualmente é a mesma formulada na época da elaboração do Plano de Manejo. Para a trilha Mãe da Floresta foi determinado o máximo de 10 a 12 pessoas na trilha simultaneamente divididos em grupos de, no máximo, 5 a 6 pessoas, com restrição de haver no máximo 6 pessoas nas áreas de banho. Contudo esta capacidade de carga já está desatualizada, uma vez que a trilha foi revitalizada e foram inseridos mecanismos para diminuir o impacto e melhorar as condições da trilha.

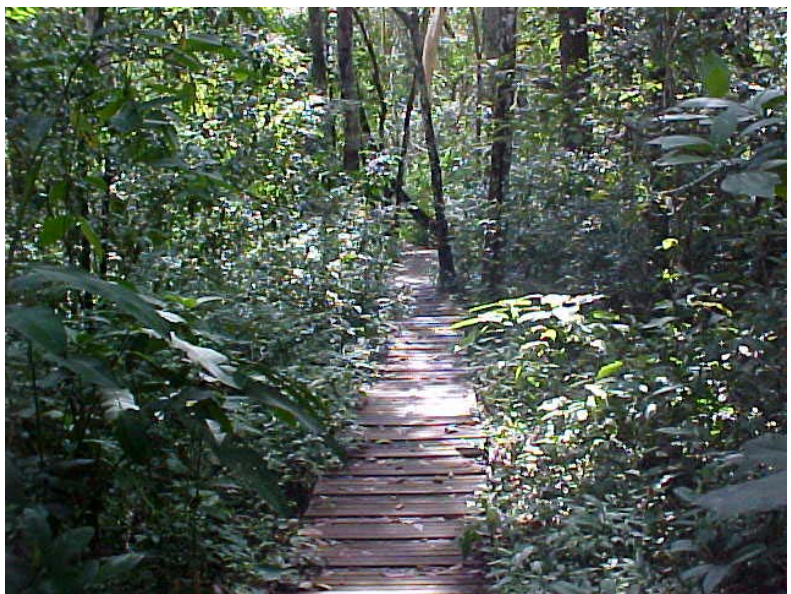

FIGURA 12. Trilha de Madeira

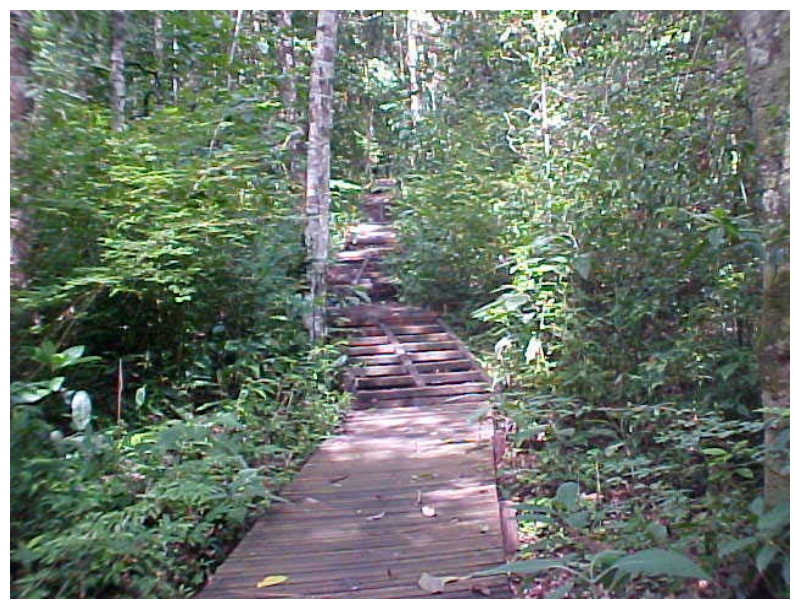

FIGURA 13. Trilha e escada em Madeira 


\subsection{Metodologia}

Para a realização deste estudo de caso tomou-se como base os estudos de dois autores, ALDERMAN (1984) e MESQUITA (1999) que trabalharam especificamente com a questão de reservas privadas na América Latina e na África. Carlos Alberto Mesquita buscou adaptar uma metodologia desenvolvida no Centro Agronómico Tropical de Investigación e Enseñanza de Turrialba, na Costa Rica, para a determinação da efetividade de manejo em áreas protegidas. E Cláudia Alderman analisou o ecoturismo nas reservas privadas sob o ponto de vista econômico.

No presente trabalho, como estão envolvidos dois aspectos diferentes e interdependentes - o ecoturismo e a manutenção de uma unidade de conservação buscou-se unir as duas experiências na tentativa de responder a necessidade de avaliação do desenvolvimento da atividade ecoturística em uma unidade de conservação, diante da perspectiva de retorno econômico e social e de conservação da cultura e do meio ambiente local.

Para tanto foi feito primeiro o exame detalhado do Plano de Manejo elaborado pela FUNATURA, seguido de entrevistas orientadas com os proprietários e conversas com os funcionários, que possibilitaram a avaliação da efetividade do manejo a partir de uma melhor visualização do objeto.

Paralelamente foram feitas observações in loco a fim de apreciar as atividades desenvolvidas e o cotidiano do local, inclusive da fazenda. Foi possível acompanhar o trabalho de educação ambiental com um grupo de alunos que estão se preparando para se tornarem condutores de ecoturismo e a recepção a diferentes grupos de visitantes, muitos deles de estrangeiros. E também, acompanhar a realização de uma outra entrevista feita por uma ONG de Goiânia - a NATIVA.

Como dados secundários ainda foram consultadas as matérias jornalísticas, audiovisuais e impressas, sobre o Santuário e os livro de visitação. 
Tabela 2: MATRIZ DE ÂMBITOS, VARIÁVEIS E SUB-VARIÁVEIS

\begin{tabular}{|c|c|c|}
\hline \multirow{4}{*}{ Legal } & \multirow{2}{*}{ Posse e domínio da terra } & Domínio legal \\
\hline & & Conflitos pela posse \\
\hline & Legislação ambiental & \\
\hline & Reconhecimento da área & \\
\hline \multirow{10}{*}{ Político } & Apoio da comunidade & \\
\hline & \multirow{5}{*}{ Apoio institucional } & $\begin{array}{l}\text { Clareza de jurisdição e } \\
\text { atribuições }\end{array}$ \\
\hline & & $\begin{array}{l}\text { Coordenação para solução de } \\
\text { problemas }\end{array}$ \\
\hline & & Intercambio de informação \\
\hline & & Alcance \\
\hline & & Estabilidade \\
\hline & \multirow{4}{*}{ Recursos humanos } & Incentivo ao bom rendimento \\
\hline & & Salários \\
\hline & & Capacitação \\
\hline & & Autoridade dos funcionários \\
\hline \multirow{8}{*}{ Administrativo } & \multirow{4}{*}{ Pessoal } & Quantidade \\
\hline & & Nível de instrução \\
\hline & & Experiência na função \\
\hline & & Motivação \\
\hline & \multirow{4}{*}{ Infra-estrutura } & Quantidade \\
\hline & & Estado de conservação \\
\hline & & Localização \\
\hline & & Funcionalidade \\
\hline \multirow{5}{*}{ Planejamento } & \multirow{5}{*}{ Plano de Manejo } & Existência e atualização \\
\hline & & Equipe de elaboração \\
\hline & & Nível de implantação \\
\hline & & Nível de planejamento \\
\hline & & Zoneamento \\
\hline \multirow{2}{*}{ Programas de manejo } & \multirow{2}{*}{ (cada um dos programas existentes) } & Existência e atualização \\
\hline & & Nível de implantação \\
\hline \multirow{7}{*}{ Informação } & \multirow{2}{*}{ Informação biofísica } & Existência e atualização \\
\hline & & Organização e disponibilidade \\
\hline & \multirow{2}{*}{ Informação cartográfica } & Existência e atualização \\
\hline & & Organização e disponibilidade \\
\hline & \multirow{2}{*}{ Informação socioeconômica } & Existência e atualização \\
\hline & & Organização e disponibilidade \\
\hline & Monitoramento e retroalimentação & \\
\hline \multirow{2}{*}{ Usos Atuais } & \multirow{2}{*}{ (cada um dos usos da área) } & Compatibilidade com objetivos \\
\hline & & Manejo do uso \\
\hline \multirow{3}{*}{ Biogeografia } & Tamanho & \\
\hline & Forma & \\
\hline & Conectividade & \\
\hline
\end{tabular}

Para a análise da efetividade de manejo foi adaptada e utilizada a metodologia encontrada nos trabalhos de Mesquita (1999 e 2002) como instrumento 
para avaliar a RPPN quanto aos objetivos de conservação e manejo da área. Para tanto foram considerados oito âmbitos apresentados na tabela acima, que abrangem a totalidade do manejo.

Posteriormente foi aplicado um questionário complementar (em anexo) com o objetivo de aprofundar a análise da atividade ecoturística em relação aos quatro princípios fundamentais definidos neste trabalho. No decorrer do trabalho houve a oportunidade da consulta a alguns documentos da FUNATURA sobre a Vagafogo e de conversar com os profissionais da ONG para saber mais sobre o Santuário.

Para a apreciação dos resultados partiu-se primeiro para uma visão global do objeto, focalizando os pontos fortes e críticos do manejo da reserva, a partir dos diferentes âmbitos envolvidos na avaliação. Depois foi feita a avaliação da atividade ecoturística que se desenvolve na reserva.

Em seguida, alguns dos fatores críticos e dos fatores de sucesso do empreendimento foram particularmente abordados. Por fim, foram feitas algumas sugestões para o melhor desenvolvimento da atividade. 


\section{Resultados e Discussão}

\subsection{Efetividade do manejo}

A avaliação da efetividade de manejo do Santuário Vagafogo resultou entre regular e satisfatória, com $72 \%$ de efetividade ${ }^{16}$. Isso significa dizer que estão acontecendo ações importantes para a gestão da reserva, mas que existem deficiências no manejo e, em conseqüência, alguns objetivos básicos podem não estar sendo atendidos.

$\mathrm{Na}$ prática, isso significa que a manutenção dos objetivos iniciais, de desenvolvimento do ecoturismo aliado à conservação e à produção orgânica, somada à atual estrutura administrativa, tem levado a um manejo entre regular $\mathrm{e}$ satisfatório, mas que as deficiências como a falta de revisão do Plano de Manejo e o baixo monitoramento da reserva podem acarretar em prejuízo de algum outro projeto.

TABELA 3: EFETIVIDADE DE MANEJO, POR ÂMBITOS

\begin{tabular}{lc}
\hline \multicolumn{1}{c}{ Âmbitos } & SVS Vagafogo \\
\hline Legal & $93,75 \%$ \\
Político & $75,40 \%$ \\
Administrativo & $84,40 \%$ \\
Planejamento & $65,00 \%$ \\
Programas de Manejo & $52,50 \%$ \\
Informação & $62,50 \%$ \\
Usos Atuais & $100,00 \%$ \\
Biogeografia & $41,66 \%$ \\
GERAL & $72,00 \%$ \\
\hline
\end{tabular}

Fonte: Pesquisa de campo

\footnotetext{
${ }^{16}$ A metodologia utilizada por Mesquita serviu para orientar a avaliação da RPPN quanto à conservação e ao manejo da área de forma que é apenas um meio de análise e não uma forma de classificação da reserva, visto que ela não está sendo comparada com nenhuma outra. O nível de efetividade alcançado é relativo ao cenário ideal que foi construído para a mesma. Ou seja, dentro do que se espera da reserva, no momento, ela está cumprindo $72 \%$ de sua meta.
} 
$\mathrm{Na}$ avaliação da efetividade foi possível verificar, com base nos valores obtidos em cada esfera, os pontos fortes e os pontos críticos no manejo da reserva. Os pontos fortes encontram-se nas esferas legal, administrativa e de usos.

Na esfera legal, além da Vagafogo apresentar-se totalmente de acordo com as exigências legais para esse tipo de reserva, garantindo sua legalidade, a legislação sobre RPPN em vigor tem atendido às necessidades dos proprietários, de forma que trouxe os benefícios que se desejava e, ao mesmo tempo, não se impôs como obstáculo para as atividades pretendidas. Mesmo as lacunas, que ainda existem na legislação, não tem acarretado em prejuízo para o manejo e conservação da reserva.

Do ponto de vista administrativo, as infra-estruturas e a equipe que trabalha na fazenda estão, até o momento, atendendo às necessidades dos proprietários e da visitação. Contudo o proprietário já prevê a ampliação da cozinha e da área de mesas e, conseqüentemente, do atendimento e espera que, no futuro, haja um biólogo no local para fazer o acompanhamento da reserva.

No âmbito dos usos atuais, considerando que o único uso que vem ocorrendo dentro da área de conservação é o ecoturismo, na zona destinada a esta atividade, os usos estão totalmente adequados com os objetivos da unidade, visto que esta foi criada para dar condição ao desenvolvimento sustentável do ecoturismo sem abrir mão da produção orgânica.

Quanto aos pontos críticos do manejo, verificou-se que no âmbito dos programas de manejo ocorre o mesmo problema que nas esferas de informações e de planejamento: a desatualização do Plano de Manejo e, conseqüentemente, de todos os programas e subprogramas.

O plano de manejo - instrumento que possibilita o conhecimento mais profundo da área - apesar de ser bastante detalhado, é muito antigo, totalizando onze anos desde que foi elaborado. Isso acarreta em grande defasagem de informações. Ou seja, são onze anos abertos à visitação pública e sem avaliação ou acompanhamento de como essa área vem reagindo. Nesse ponto, chega-se a outro problema: a falta de monitoramento sistematizado para acompanhar e avaliar a evolução dos processos naturais dos ecossistemas protegidos e o desenvolvimento do ecoturismo. 
O acompanhamento tem sido feito pelo proprietário, informalmente, durante o desenvolvimento das atividades diárias e está enfocado na visitação pública. Contudo esse monitoramento é limitado, já que não conta com o apoio de biólogos ou engenheiros florestais que possam avaliar cientificamente os impactos causados pelas atividades no decorrer desses anos.

Mesmo assim, esse acompanhamento tem possibilitado ao proprietário perceber os impactos na trilha e tomar decisões de acordo com as necessidades do momento, ainda que em caráter mais corretivo do que preventivo. De acordo com o proprietário, ele tem usado do bom senso nas tomadas de decisão quanto ao manejo da área, procurando sempre dar prioridade à conservação do meio ambiente e depois ao conforto e satisfação do visitante, valorizando a estética sem alterar demais o meio.

O que pôde ser constatado é que este tipo de monitoramento tem dado certo, até agora, para a trilha "Mãe da Floresta", inclusive acarretando em ações importantes para a conservação e a sustentabilidade desta, contudo esse acompanhamento não é feito com a mesma intensidade no restante da reserva. Com a expansão da atividade e dos locais de visitação, já prevista pelo proprietário, é imprescindível que se adote um sistema de monitoramento para acompanhar e avaliar a evolução do ecoturismo e do meio ambiente local, de preferência com o apoio de profissional capacitado, possibilitando melhor manejo da reserva.

Ainda quanto aos programas, existem mais dois subprogramas que apresentaram baixo nível de execução: os subprogramas de recreação e lazer e de interpretação ambiental. Esses subprogramas ainda não estão totalmente implantados, o que acarretou os baixos índices. Contudo isso não chega a ser problema para a reserva, já que a não implantação de todas as trilhas resulta em menor escala para a atividade e diminuição dos possíveis impactos ambientais. De qualquer forma, a conclusão desses programas faz parte do objetivo dos proprietários.

O ultimo ponto crítico diz respeito às características biogeográficas. Estas são importantes na questão da manutenção da fauna e flora da área protegida em longo prazo. Nesse sentido, são levados em consideração fatores como formato, tamanho e isolamento. Para a Vagafogo os problemas estão no tamanho reduzido e 
no formato retangular. Essas características, no entanto, estão fora do alcance da propriedade que, em compensação, faz fronteira com outra reserva - a RPPN Flor das Águas, da propriedade da FUNATURA. De acordo com a FUNATURA, um dos objetivos da Flor das Águas é garantir a viabilidade ecológica da Vagafogo, ampliando em 43,31 hectares a área protegia da mata. Essas duas propriedades não possuem cercas entre si que limitem a passagem de animais, estando totalmente integradas.

\subsection{Desenvolvimento do Ecoturismo}

De acordo com os dados levantados, as principais razões para o estabelecimento da reserva foram a conservação, o turismo natural, a educação ambiental e a pesquisa científica, que se transformaram em objetivos da fazenda aliados à produção orgânica.

Nos últimos anos, o número de visitantes ultrapassou 10 mil pessoas por ano, ou seja mais ou menos 830 visitantes por mês e 41 pessoas por dia (considerando 5 dias de funcionamento por semana). ${ }^{17}$ Isso não quer dizer que todas essas pessoas percorrem a trilha, visto que os números englobam tanto os visitantes que passeiam pela trilha como aqueles que apenas consomem o brunch ou compram produtos.

\footnotetext{
${ }^{17}$ Não foi possível fazer o levantamento de turistas estrangeiros, mas é facilmente constatado, em observação in loco, que esse número é grande. A explicação para isso pode estar em três fatores fundamentais: a reserva está inserida em dois guias turísticos internacionais; os proprietários dominam a língua inglesa e desde o começo da visitação, até mesmo antes disso, o local já recebia visitantes vindos das embaixadas em Brasília.
} 
TABELA 4. NÚMERO DE VISITANTES POR ANO E CRESCIMENTO EM \%

\begin{tabular}{|c|c|c|}
\hline Ano & $\begin{array}{l}\text { Número de } \\
\text { visitantes }\end{array}$ & $\begin{array}{c}\text { Crescimento percentual em relação ao } \\
\text { ano anterior }\end{array}$ \\
\hline 1992 & 1.260 & \\
\hline 1993 & 3.177 & $52,14 \%$ \\
\hline 1994 & 2.593 & $18,38 \%$ \\
\hline 1995 & 3.901 & $50,44 \%$ \\
\hline 1996 & 5.087 & $30,40 \%$ \\
\hline 1997 & 5.722 & $12,50 \%$ \\
\hline 1998 & 6.340 & $10,80 \%$ \\
\hline 1999 & 7.370 & $16,25 \%$ \\
\hline 2000 & 8.340 & $13,15 \%$ \\
\hline 2001 & 10.085 & $21,00 \%$ \\
\hline 2002 & 10.383 & $3,00 \%$ \\
\hline TOTAL & 64.258 & $724 \%$ ou $23 \%$ ao ano \\
\hline
\end{tabular}

Fonte: Pesquisa de Campo

O gasto médio por visitante, tomando por base as informações cedidas pelo proprietário, é de $R \$ 12,00$ por pessoa, gerando um lucro líquido de $R \$$ $3.000,00$ por mês. Ainda de acordo com o proprietário, $40 \%$ da receita da fazenda é proveniente dos ingressos para a trilha e o restante é resultado da venda do brunch e dos produtos naturais. Segundo ele, somente a receita com os ingressos não seria suficiente para viabilizar economicamente o local, confirmando a importância de se diversificar as atividades, de forma que as rendas sejam complementares.

Tomando como base a avaliação da efetividade de manejo da reserva pode-se dizer que, apesar de haver algumas falhas, os objetivos da conservação tem sido atingidos, inclusive com ações de compensação do impacto ambiental. Soma-se a isso o fato de que a reserva foi criada por causa da demanda por visitação, como instrumento para controlar e assegurar a manutenção da área, buscando diminuir ao máximo o impacto da visitação sobre o meio ambiente. Dessa forma a própria iniciativa de implantação do turismo natural na fazenda já teve como resultado a criação de área de conservação da biodiversidade em caráter perpétuo, sustentando a hipótese de que o ecoturismo pode incentivar a conservação ambiental. 
Também foi possível perceber que a atividade tem gerado 0 desenvolvimento da fazenda. Nesses 11 anos, a atividade tem se mostrado ambientalmente sustentável e economicamente viável, gerando lucros que tem viabilizado a manutenção da fazenda nos moldes de conservação propostos. Também tem garantido a manutenção de várias famílias, direta e indiretamente, pois além de gerar empregos diretos - a implantação da atividade fez com que dobrasse o número de funcionários fixos na fazenda, esta também gera empregos indiretos e temporários, como por exemplo na construção da infra-estrutura que existe no local e incentivado o empreendedorismo de outros produtores por meio da terceirização de produtos que não são produzidos no local.

Tais produtos usam a marca Vagafogo, que já possui um mercado estabelecido e um nome que está ligado ao conceito de produto orgânico de qualidade. Passando a ter aumentada a oportunidade de negócio para outros produtores, que podem contar o com suporte e com a demanda turística da Vagafogo. Dessa forma o ecoturismo também está promovendo oportunidades de desenvolvimento para a comunidade. E igualmente está valorizando a cultura local, pois parte do princípio de só oferecer produtos da região ${ }^{18}$, tais como o pequi e a cagaita, divulgando as riquezas do cerrado.

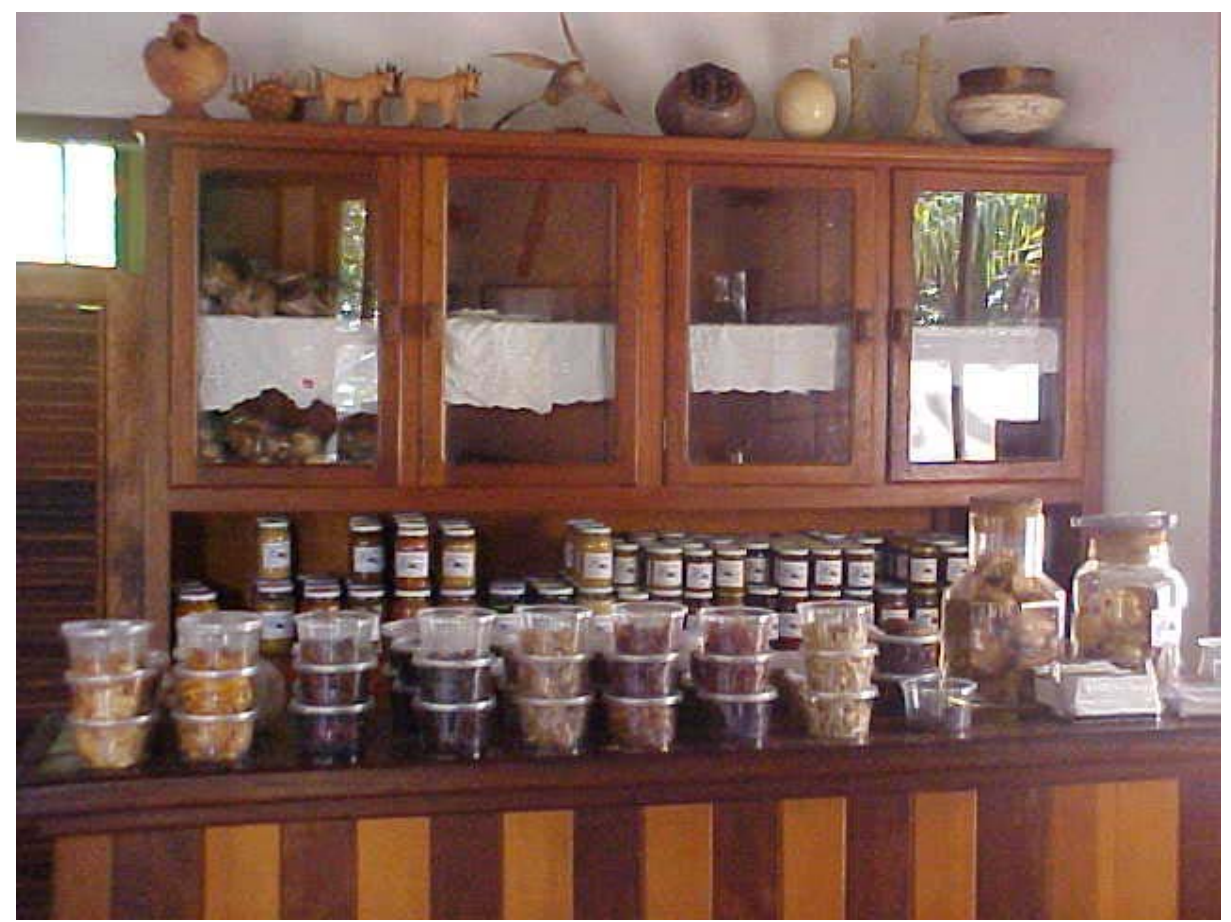

FIGURA 14. Produtos à venda no centro de visitantes

\footnotetext{
${ }^{18}$ Com exceção da geléia de morango e de damasco, por exigência dos clientes. 
Um exemplo disso é o projeto de agroindústria, do qual a Vagafogo faz parte, para produzir, beneficiar e divulgar o Baru, castanha nativa do cerrado até então pouco conhecida e valorizada, mesmo na região, mas que substitui perfeitamente outras castanhas como a noz e a castanha-de-caju .

A Associação de Produtores de Baru tem financiamento do GEF (Fundo para o Meio Ambiente Mundial) no valor de 3 mil dólares, apoio da EMBRAPA, na construção de uma usina de beneficiamento e já se tornou OSCIP - Organização da Sociedade Civil de Interesse Público. O projeto vai beneficiar moradores locais e de comunidades vizinhas e RPPNs.

Um passo importante para esse projeto começou a ser dado no sentido de divulgar o uso dessa castanha, nacional e internacionalmente: Um hotel de grande porte de Brasília está interessado em introduzir produtos do cerrado na sua culinária, podendo representar um grande marketing para o Baru e conseqüentemente para o Cerrado. Esse contato com os produtos dos cerrado aconteceu via Vagafogo, demonstrando que mesmo a iniciativa de um pequeno empreendimento em valorizar a cultura local pode gerar frutos e beneficiar toda uma comunidade.

A promoção da consciência ambiental também foi um dos objetivos da Vagafogo desde sua criação, que conta com projetos de Educação Ambiental. Atualmente além da trilha interpretativa (que ainda está sendo concluída) e das visitações de grupos escolares para aprender sobre educação ambiental, é costume do proprietário conversar com os visitantes com o intuito de sensibilizá-los para a conscientização ambiental. A Sr. Evandro relatou que, com uma ou outra exceção, o comportamento dos visitantes no meio ambiente é de respeito às normas estabelecidas. Outro passo importante nesse sentido é o Fundo Vagafogo de Educação Ambiental, que mesmo ainda não sendo muito utilizado já está disponível para as escolas públicas. 


\section{Conclusã̃o e Recomendaçỗes}

Dessa forma pode-se concluir que o Santuário de Vida Silvestre Vagafogo tem cumprido seu papel tanto no desenvolvimento sustentável do ecoturismo estando em sintonia com os fundamentos básicos desta atividade - como no esforço de conservação ambiental. E que o ecoturismo tem se mostrado um ótimo instrumento de viabilidade e sustentabilidade econômica e ecológica para a reserva.

Contudo existem alguns fatores que foram fundamentais para o sucesso do SVS Vagafogo, como projeto de ecoturismo e como RPPN, e que devem ser exaltados.

O primeiro deles é o forte apoio que a fazenda recebeu da Fundação PróNatureza - FUNATURA, para a criação da reserva e implantação do ecoturismo, tanto do ponto de vista consultivo, por meio do suporte necessário à implantação da atividade de visitação com base sustentável, como financeiro, pois foi por meio dessa ONG que os financiamentos foram conseguidos. Sem esquecer, é claro, das ONG's ou organismos que financiaram que os projetos.

O segundo fator de sucesso está no fato dos proprietários estarem a frente da administração da fazenda e das atividades ali presentes. Fazendo com que o claro desejo de conservação esteja sempre acima dos interesses econômicos, garantindo a qualidade dos produtos e serviços oferecidos e fazendo com que todas as pessoas que trabalham com eles estejam engajadas no mesmo projeto.

E o terceiro aspecto que tem colaborado para o desempenho do Santuário diz respeito à infra-estrutura instalada, uma vez que ela já iniciou com uma infraestrutura que dava base para o desenvolvimento da atividade e que está constantemente sendo modernizada e adequada para atender à demanda das atividades realizadas na área. Nos dois últimos anos por exemplo, foi revitalizada a trilha "Mãe da Floresta" no interesse de atender melhor aos visitantes e à necessidade de conservação do ambiente, foi construída a base da futura torre de observação de aves e foi erguida uma nova área, o Gazebo, para atender, principalmente, aos grupos de estudantes. 
No interesse de colaborar para o incremento do ecoturismo no local e para os esforços de conservação são dadas algumas sugestões:

- Atualizar o Plano de Manejo;

- Adotar planos operacionais anuais para a reserva;

- Fazer o controle da quantidade de pessoas que percorrem a trilha e de quantas consomem o brunch de forma a ter maior conhecimento sobre a lucratividade da reserva e sobre a capacidade de carga. Esse levantamento será importante tanto no momento de reavaliar o cálculo da capacidade de carga da trilha como para fazer novos investimentos, de forma mais planejada;

- Verificar a viabilidade de abrir visitação para o turismo especializado, como turismo científico e observação de pássaros, principalmente devido a potencialidade para tais atividades;

- Concluir a instalação de painéis interpretativos na trilha "Mãe da Floresta", melhorando o nível de informações sobre o local e a qualidade da visita;

- Melhorar o folheto informativo, incluindo informações atualizadas sobre a fauna e flora e sobre a antiga lavra de ouro, principal atrativo histórico da trilha "Mãe da Floresta";

- Buscar novas parcerias com organizações e instituições, como instituições de ensino, em Brasília, em Goiânia e em Anápolis;

- Para viabilizar a investigação científica, um dos objetivos da RPPN, é interessante a instalação de algum tipo de alojamento. Essa facilidade também pode colaborar para a adoção de estagiários para o monitoramento, por exemplo;

- Elaborar plano de gestão de recursos para cobrir gastos com restauração de infra-estrutura ou ambientes degradados pela visitação, monitoramento e operações emergenciais;

○ Desenvolver projeto de capacitação para os funcionários. 


\section{Bíbliografia citada}

ALDERMAN, C.L. 1994. The economics and the role of privately-owned lands used for nature tourism, education and conservation. In: Munasinghe, M; Mc Neely, J. Eds. Protected Areas, Economic and Policy: linking conservacion and sustainable development. World Bank/ IUCN, 1994.

BARROS II, Sílvio de. Programa de Desenvolvimento de Pólo Ecoturístico In: Anais do I Seminário de Ecoturismo do Distrito federal, do entorno e de Goiás. Brasília: SEBRAE/DF: SEBRAE/GO: Secretaria de Turismo do Distrito Federal, 1996.

BOO, Elizabeth. O 'Boom' do Ecoturismo: planejamento para o desenvolvimento e manejo. 2.ed. Tradução de: Peter Midkiff. Revisão de: Flávia Lacerda. [s.I]: WWF, 1994.

CAIUT, José Aurélio. Ecoturismo em Reservas Particulares do Patrimônio Natural, Uma Saída Viável. In: Anais do III Congresso Brasileiro de Unidades de Conservação. Fortaleza: Rede Nacional Pró-Unidades de Conservação: Fundação O Boticário de Proteção à Natureza: Associação Caatinga, 2002. v.1.

COSTA, C.M.R. (org.). Anais do I Seminário de Reservas Particulares de Minas Gerais. Publicação em CD-ROM. Belo horizonte: Fundação Biodiversitas, 2001.

DEAN, Warren. A ferro e fogo: a história da devastação da Mata Atlântica brasileira. São Paulo: Companhia das Letras, 1996.

DIEGUES, A.C.S. As áreas naturais protegidas, o turismo e as populações tradicionais. In: Serrano, Célia. Viagens à natureza. Turismo, Cultura e Ambiente. Campinas: Papirus, 1997

DRUMMOND, José Augusto. O sistema brasileiro de parques nacionais: análise de uma política ambiental (cadernos do CEG, n.1. Niterói: EDUFF, 1997.

EMBRATUR. Diretrizes para uma Política Nacional de Ecoturismo. Brasília: MINISTÉRIO DA INDÚSTRIA, DO COMÉRCIO E DO TURISMO: MINISTÉRIO DO MEIO AMBIENTE E DA AMAZÔNIA LEGAL, 1994. Disponível em www.geocities.com/yosemite/rapids/4055/textos.html. Consultado em setembro/02

FENNELL, David A. Ecoturismo uma introdução. David A. Fennell; tradução de Inês Lohbauer. - São Paulo: Contexto, 2002. - (Coleção Turismo Contexto)

FILION, Fern L.; FOLEY, James P. ; JACQUEMOT, André J. The Economics of Global Ecotourism. In Munasinghe, M \& Mc Neely, J. Eds. Protected Areas, Economic and Policy: linking conservation and sustainable development. World Bank/ IUCN, 1994. 
FERNANDES, R. V.; Rambaldi, D. M.; Bento, M.I. S.; Matsuo, P. M. A RPPN Reserva Particular do Patrimônio Natural - Como Mecanismo de Proteção Legal para o Habitat do Mico-Leão-Dourado (Leontopithecus rosalia) In: Anais do II Congresso Brasileiro de Unidades de Conservação. v. 2. Campo Grande, 2000

Fundação Biodiversitas. Programa de Unidades de Conservação. Disponível em http://www.bdt.org.br/biodiversitas/uc. Consultado em 12/03/03.

GÓMEZ-POMPA, A. \& BURLEY, F.W. The management of natural tropical forests. In: Gómez-Pompa A.; Whitmore, T.C. \& Hadley M. Rain forest regeneration and management. MAB \& UNESCO. Paris; Parthenon, 1991, 3-18. Man and the Biosphere Series. v. 6.

IBAMA. Manual informativo do programa de Reservas Particulares do Patrimônio Natural. Para saber mais. Projeto IBAMA/ RPPN. Brasília; FUNBIO: IBAMA, s/d.

. Marco Conceitual das Unidades de Conservação Federais do Brasil. Brasília, 1997.

MESQUITA, C.A.B. Caracterización de las reservas naturales privadas en América Latina. Tesis Mag. Sc. Turrialba, Costa Rica:CATIE, 1999.

Efetividade de manejo em áreas protegidas: quatro estudos de caso em Reservas Particulares do Patrimônio Natural, Brasil. 2002.

MESQUITA, C. A. B. ; LEOPOLDINO, F. S. Incentivando e Apoiando a Criação, Manejo e Integração entre Reservas Particulares do Patrimônio Natural (RPPNS) In: Anais do III Congresso Brasileiro de Unidades de Conservação. Fortaleza: Rede Nacional Pró-Unidades de Conservação: Fundação $O$ Boticário de Proteção à Natureza: Associação Caatinga, 2002. v 1.

MILANO, Miguel Serediuk; BERNARDES, Ângela Tresinari; FERREIRA, M. Loourdes. Mitos no manejo de unidades de conservação no Brasil, ou a verdadeira ameaça. In: Anais do II CONGRESSO BRASILEIRO DE UNIDADES DE CONSERVAÇÃO, 2, 2000, Campo Grande. Anais Campo Grande: Rede Nacional Pró-Unidades de Conservação: Fundação O Boticário de Proteção à Natureza, 2000. v. 1, p. 11-25.

MMA. (2003a) Unidades de Conservação. Disponível no site: http://www.mma.gov.br/port/sbf/dap/apconser.html. Consultado em 12 de março de 2003.

(2003b) Para que Parques? Disponível no site: http://www.mma.gov.br/port/sbf/dap/apbpparq.htm. Consultado em 12 de março de 2003.

(2003c) Histórico das Áreas Protegidas Disponível no site: 
http://www.mma.gov.br/port/sbf/dap/apbhist.html. Consultado em 12 de março de 2003.

MOURÃO, Roberto M. F. Ecoturismo e Turismo Especializado: conceitos e critérios. Versão 1.0 Programa MPE. Funbio set 2001 Consultado em http://www.ecobrasil.org.br em nov/2002

MORSELLO, Carla ; MONTOVANI, Walter. Mecanismos de Seleção de RPPN: uma crítica. In: Anais do I Congresso Brasileiro de Unidades de Conservação. Vol. II. Curitiba: IAP: UNILIVRE: Rede Nacional Pro Unidade de Conservação, 1997.

MURTA, Stella Maris, Interpretação do Patrimônio para o Desenvolvimento do Turismo Sustentado. In :Anais do I Seminário de ecoturismo do Distrito federal, do entorno e de Goiás. SEBRAE/DF: SEBRAE/GO: Secretaria de Turismo do Distrito Federal: Brasília, 1996.

NUNES, K C. A. Em Busca da Sustentabilidade - a difícil tarefa de se viabilizar uma RPPN. In: Anais do III Congresso Brasileiro de Unidades de Conservação. Fortaleza: Rede Nacional Pró-Unidades de Conservação: Fundação O Boticário de Proteção à Natureza: Associação Caatinga, 2002. v. 1.

PÁDUA, $M^{a}$ Tereza J. Bioma Cerrado In: Anais do I Seminário de ecoturismo do Distrito federal, do entorno e de Goiás. Brasília: SEBRAE/DF: SEBRAE/GO: Secretaria de Turismo do Distrito Federal, 1996.

Plano de Manejo do Santuário de Vida Silvestre da Fazenda Vagafogo - Pirenópolis/Goiás. Brasília: FUNATURA, 1990.

PEREIRA, Célia. A Experiência do IBAMA na Criação de Reservas Particulares do Patrimônio Natural. In: Anais do III Congresso Brasileiro de Unidades de Conservação. Fortaleza: Rede Nacional Pró-Unidades de Conservação: Fundação O Boticário de Proteção à Natureza: Associação Caatinga, 2002. v.1.

PISKULICH, Zdenka. Visión general de la conservación privada en Latinoamérica: áreas protegidas privadas, servidumbres ecológicas, incentivos. In: Áreas Protegidas Departamentales, Municipales y Privadas en Bolívia: Formulacion de políticas para su creación y gestión. Tarija, Bolívia: PROMETA (con el aporte de Tinker Foundation), 2001.

SOUZA, Paulo Roberto P. Além do Estado: os papeis da iniciativa privada e do terceiro setor na implementação e manejo de unidades de conservação. In: Milano, Miguel S. (org.). Unidades de Conservação: atualidades e tendências. Curitiba: Fundação O Boticário de proteção à natureza, 2002.

TIES. Ecotourism Statistical Fact Sheet. The International Ecotourism Society, 2000 Consultado na http://www.ecotourism.org em fevereiro/2003

TORRECILHA, Sylvia ; LOUREIRO, Wilson. A contribuição das RPPNs na construção das políticas públicas estaduais de conservação da biodiversidade. In: Anais do II Congresso Brasileiro de Unidades de Conservação. v. 2. Campo 
Grande, 2000

WIEDMANN, Sônia M. P.. As reservas particulares do patrimônio natural. In Anais do I Congresso Brasileiro de Unidades de Conservação. Vol. II. Curitiba: IAP: UNILIVRE: Rede Nacional Pro Unidade de Conservação, 1997.

WORKSHOP ÁREAS DE CONSERVAÇÃO DE CARÁTER PRIVADO. Anais do WORKSHOP ÁREAS DE CONSERVAÇÃO DE CARÁTER PRIVADO: modelos alternativos e incentivos. Rio de janeiro: Instituto Iguaçu de Pesquisa e Preservação Ambiental, 1994.

WWF. Turismo Sustentável: lições mundiais e recomendações para o Brasil. Brasília: WWF, 2001 


\section{Anexo A - Legislação}

\section{Sistema Nacional de Unidades de Conservação da Natureza - SNUC: ${ }^{19} \quad$ Lei No 9.985 de 18 de Jullho de 2000}

Art. 21 - A Reserva Particular do Patrimônio Natural é uma área privada, gravada com perpetuidade, com o objetivo de conservar a diversidade biológica.

$\S 1^{\circ}$ - O gravame de que trata este artigo constará de termo de compromisso assinado perante o órgão ambiental, que verificará a existência de interesse público, e será averbado à margem da inscrição no Registro Público de Imóveis.

$2^{\circ}$ - Só poderá ser permitida, na Reserva Particular do Patrimônio Natural, conforme se dispuser em regulamento:

I - a pesquisa científica;

II - a visitação com objetivos turísticos, recreativos e educacionais.

$\S 3^{\circ}$ - Os órgãos integrantes do SNUC, sempre que possível e oportuno, prestarão orientação técnica e científica ao proprietário de Reserva Particular do Patrimônio Natural para elaboração de um Plano de Manejo ou de Proteção e Gestão da unidade."

\section{DECRETO No 1.922, DE 5 JUNHO DE $1996^{20}$}

Dispõe sobre reconhecimento das Reservas Particulares do Patrimônio Natural, e dá outras Providências.

O Presidente da República, no uso das atribuições que the confere o art. 84, inciso IV e art. 225 da Constituição, e tendo em vista o dispoto no código Florestal-Lei ${ }^{\circ}$ 4.771, de 15 de Setembro de 1965, e na Lei $n^{\circ}$ 8.171, de 17 de Janeiro de 1991.

\section{DECRETA:}

Art. $1^{\circ}$ Reserva Particular do Patrimônio Natural - RPPN é área de domínio privado a ser especialmente protegida, por iniciativa de seu proprietário, mediante reconhecimento do Poder Público, por ser considerada de relavante importância pela sua biodiversidade, ou pelo seu aspecto paisagístico, ou ainda por suas características ambientais que justifiquem ações de recuperação.

Art. $2^{\circ}$ As RPPN's terão por objetivo a proteção dos recursos ambientais representativos da região.

\footnotetext{
${ }^{19}$ GOVERNO FEDERAL. Sistema Nacional de Unidades de Conservação da Natureza - SNUC, 2000. disponível em http://www.mma.gov.br/port/sbf/dap/leisnuc1.html

${ }^{20}$ GOVERNO FEDERAL. DECRETO No 1.922, 1996. Disponível em:

http://www2.ibama.gov.br/unidades/rppn/decreto.htm 
Art. $3^{\circ}$ As RPPN's poderão ser utilizadas para o desenvolvimento de atividades de cunho cientifico, cultural, educacional, recreativo e de lazer, observado o objetivo estabelecido no artigo anterior.

$\S 1^{\circ}$ - As atividades previstas neste artigo deverão ser autorizadas ou licenciadas pelo órgão responsável pelo reconhecimento da RPPN e executadas de modo a não comprometer o equilíbrio ecológico ou colocar em perigo a sobrevivência das populações das espécies ali existentes, observada a capacidade de suporte da área, a ser prevista no plano de utilização de que trata o Art. $8^{\circ}$ inciso II deste Decreto:

$\S 2^{\circ}$ - Somente será permitido no interior das RPPN's a realização de obras e infraestrutura que sejam compatíveis e necessárias as atividades previstas no caput deste Artigo.

Art. $4^{\circ} \mathrm{A}$ área será reconhecida como Reserva Particular do Patrimônio Natural por iniciativa de seu proprietário e mediante portaria do Instituto Brasileiro do Meio Ambiente e dos Recursos Naturais Renováveis IBAMA, na esfera federal.

Art. $5^{\circ} \mathrm{O}$ Proprietário interessado em ter reconhecido seu imóvel, integral ou parcialmente, como RPPN, deverá requerer junto à Superintendência do IBAMA na Unidade da Federação onde estiver situado o imóvel ou junto ao Órgão Estadual do Meio Ambiente-OMEA, acompanhado de cópias autenticadas dos seguintes documentos:

I - título de domínio, com matrícula no cartório de registro de imóveis competente;

II - cédula de identidade do proprietário, quando se tratar de pessoa física;

III - ato de designação de representante quando se tratar de pessoa jurídica;

IV - quitação do Imposto sobre a Propriedade Territorial Rural - ITR;

V - plantas de situação indicando os limites, os confrontantes, a área a ser reconhecida e a localização da propriedade no município ou região.

Parágrafo único. Serão prioritariamente apreciados pelo órgão responsável pelo reconhecimento os requerimentos referentes aos imóveis contíguos às unidades de conservação ou áreas cujas características devam ser preservadas no interesse do patrimônio natural do país.

Art. $6^{\circ} \mathrm{O}$ órgão responsável pelo reconhecimento da RPPN, no prazo de sessenta dias, contados da data de protocolização do documento, deverá:

I - emitir laudo de vistoria do imóvel, com descrição da área, compreendendo a tipologia vegetal, a hidrologia, os atributos naturais que se destacam, o estado de conservação da área proposta, indicando as eventuais pressões potencialmente degradadoras do ambiente, relacionando as principais atividades desenvolvidas na propriedade;

II - emitir parecer, incluindo analise da documentação apresentada e, se favorável, 
solicitar ao proprietário providências no sentido de firmar, em duas vias, o termo de compromisso, de acordo com o modelo anexo a este Decreto;

III - homologar o pedido por meio de autoridade competente;

VI - publicar no Diário Oficial ato de reconhecimento da área como RPPN.

$\S 1^{\circ}$ Após a publicação do ato de reconhecimento, o proprietário deverá, no prazo de sessenta dias, promover a averbação do termo de compromisso, a que se refere o inciso II do art. $6^{\circ}$ deste Decreto, no Cartório de registro de Imóveis competente, gravando a área do imóvel reconhecida como Reserva, em caráter perpétuo, nos termos do que dispõe o art. $6^{\circ}$ da Lei $4.771 / 65$, a fim de ser emitido o título de reconhecimento definitivo.

$\S 2^{\circ} \mathrm{O}$ descumprimento, do proprietário, da obrigação referida no parágrafo anterior importará na revogação da portaria de reconhecimento.

Art. $7^{\circ}$ Será concedida, à RPPN, pelas autoridades públicas competentes, proteção assegurada pela legislação em vigor às unidades de conservação de uso indireto, sem prejuízo do direito de propriedade, que deverá ser exercido por seu titular, na defesa da Reserva, sob orientação e com apoio do órgão competente.

Parágrafo único. No exercício das atividades de fiscalização, monitoramento e orientação às RPPN's, o órgão responsável pelo reconhecimento deverá ser apoiado pelos órgãos públicos que atuam na região, podendo também obter a colaboração de entidades privadas, mediante convênios, com a anuência do proprietário do imóvel.

Art. $8^{\circ}$ Caberá ao proprietário do imóvel:

I - assegurar a manutenção dos atributos ambientais da RPPN e promover sua divulgação na região, mediante, inclusive , a colocação de placas nas vias de acesso e nos limites da área, advertindo terceiros quanto a proibição de desmatamentos, queimadas, caça, pesca, apanha, captura de animais e quaisquer outros atos que afetam ou possam afetar o meio ambiente;

II - submeter à aprovação do órgão responsável pelo reconhecimento o zoneamento e o plano de utilização da Reserva, em consonância com o previsto nos $\S \S 1^{\circ}$ e $2^{\circ}$ do art. $3^{\circ}$, deste Decreto;

III - encaminhar, anualmente e sempre que solicitado, ao órgão responsável pelo reconhecimento, relatório da situação da Reserva e das atividades desenvolvidas.

Parágrafo único. Para o cumprimento do disposto neste artigo o proprietário poderá solicitar a cooperação de entidades ambientalistas devidamente credenciadas pelo Cadastro Nacional de Entidades Ambientalista - CNEA, do Conselho Nacional do Meio Ambiente - CONAMA.

Art. $9^{\circ} \mathrm{O}$ órgão responsável pelo reconhecimento, sempre que julgar necessário, poderá realizar vistoria na Reserva ou credenciar universidades ou entidades 
ambientalistas com a finalidade de verificar se a área está sendo manejada acordo com os objetivos estabelecidos no plano de utilização.

Art. $10^{\circ}$ Os danos ou irregularidades praticadas à RPPN serão objetos de notificação a ser efetuadas pelo órgão responsável pelo reconhecimento, ao proprietário, que deverá manifestar-se no prazo a ser estabelecido.

Parágrafo único. Caso seja constatada a prática de infração ao disposto neste Decreto, o infrator estará sujeito às sanções administrativas previstas na legislação vigente, sem prejuízo de responsabilidade civil ou penal.

Art. $11^{\circ} \mathrm{O}$ proprietário poderá requerer ao Instituto Nacional de Colonização e Reforma Agrária-INCRA, a isenção do Imposto sobre a Propriedade Territorial RuralITR, para a área reconhecida como Reserva Particular do Patrimônio Natural, conforme prevê o parágrafo único do art. 104, da Lei n $8.171 / 91$.

Art. $12^{\circ}$ Os projetos necessários à implantação e gestão das RPPNs reconhecidas ou certificadas pelo IBAMA deverão ter prioridade na análise de concessão de recursos ao Fundo Nacional do Meio Ambiente-FNMA.

Art. $13^{\circ} \mathrm{A}$ propriedade que contiver RPPN no seu perímetro terá preferência na análise do pedido de concessão de crédito agrícola, pelas instituições oficiais de crédito.

Art. $14^{\circ}$ Os incentivos de que tratam os arts. 11, 12 e 13 deste Decreto somente poderão ser utilizados para as RPPNs reconhecidas pelo Poder Público Estadual ou Municipal, mediante certificação do IBAMA, que comprovará o cumprimento dos dispositivos deste Decreto.

Art. $15^{\circ}$ Caberá ao IBAMA fiscalizar o cumprimento das determinações constantes deste Decreto, e ainda solicitar o cancelamento dos incentivos concedidos, caso haja inobservância das mesmas.

Art. $16^{\circ} \mathrm{O}$ IBAMA expedirá os atos normativos complementares ao cumprimento deste Decreto.

Art. $17^{\circ}$ Este Decreto entra em vigor na data de sua publicação.

Art. $18^{\circ}$ Fica revogado o Decreto n 98.914, de 31 de janeiro de 1990.

Brasília, 5 de junho de 1996. $175^{\circ}$ da Independência e $108^{\circ}$ da República.

FERNANDO HENRIQUE CARDOSO

Gustavo Krouse 


\section{Anexo B - Fotos}

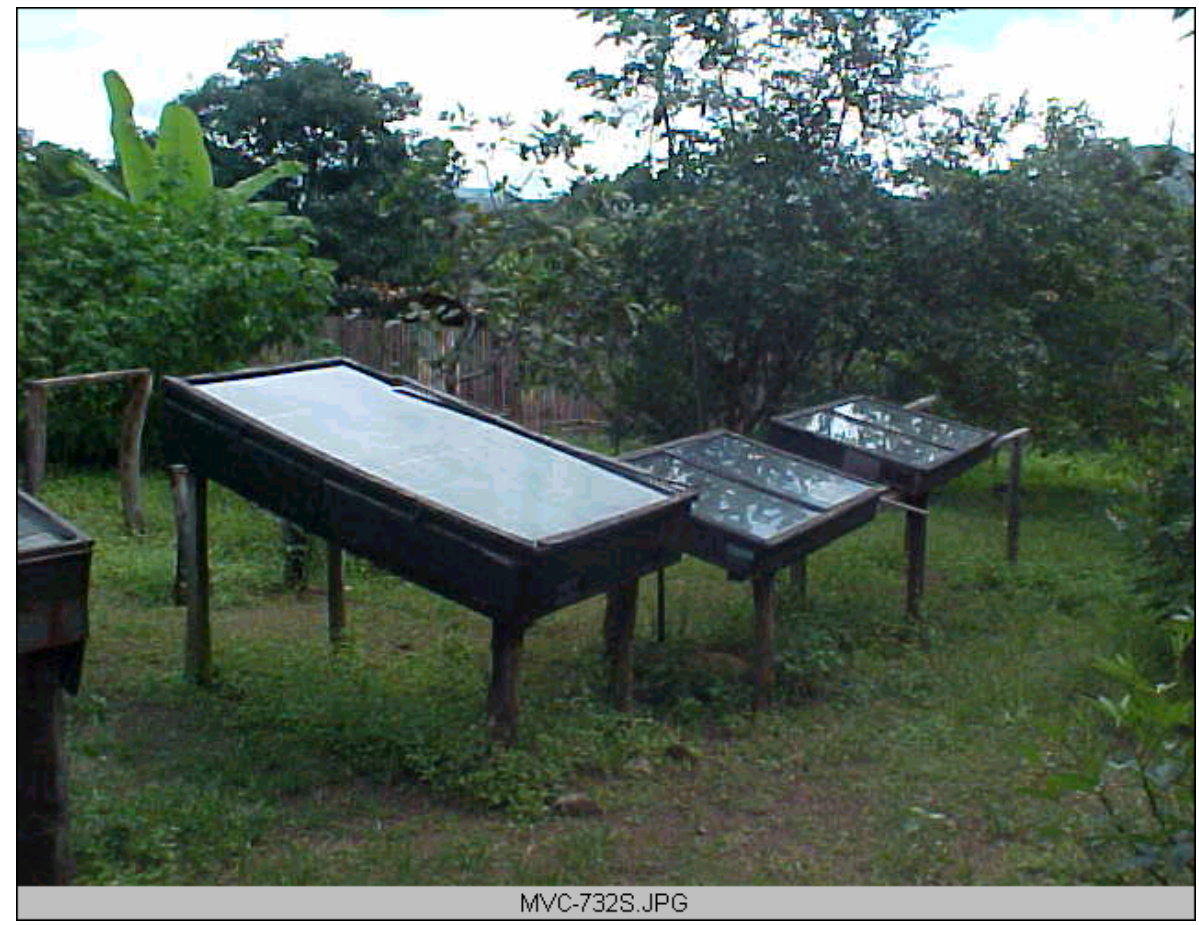

Secadores

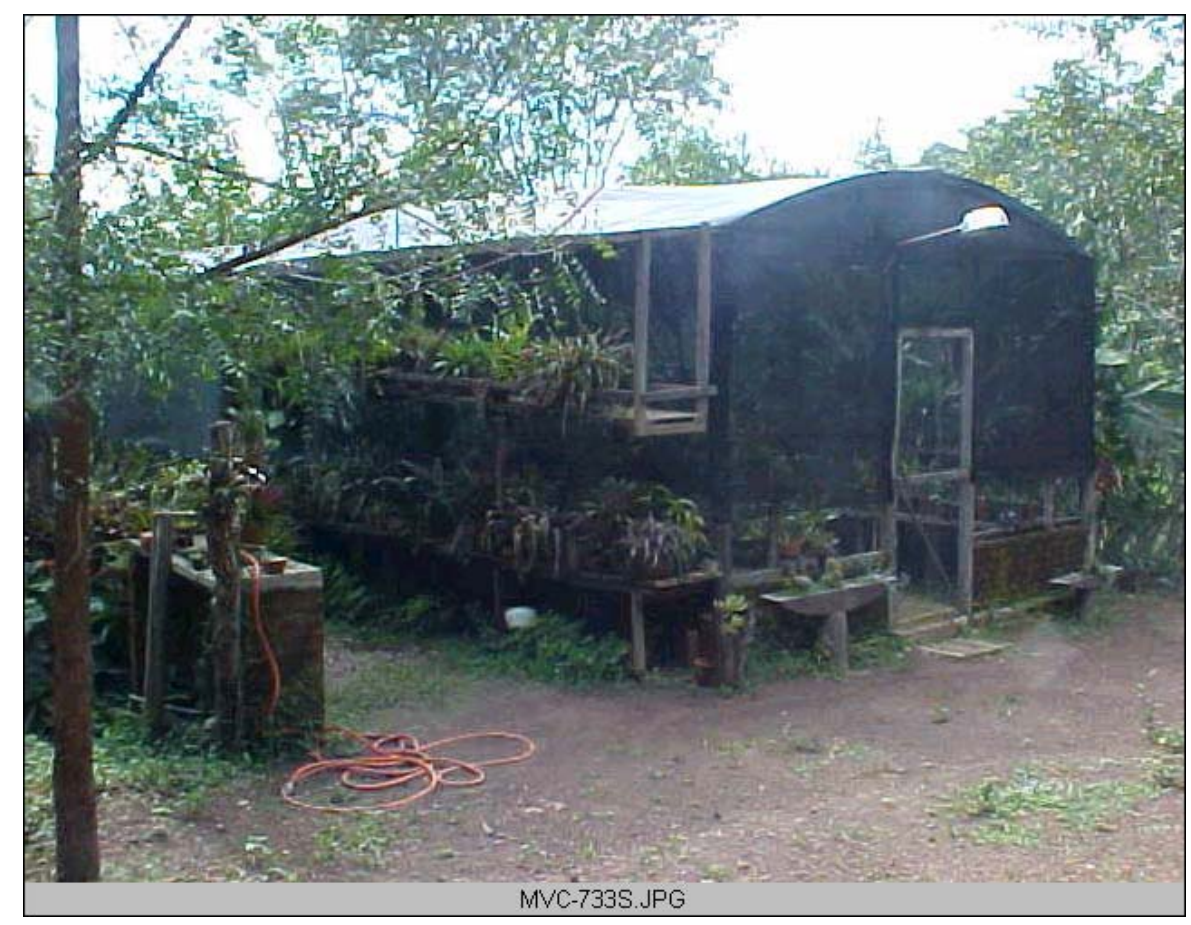

Orquidáníio 


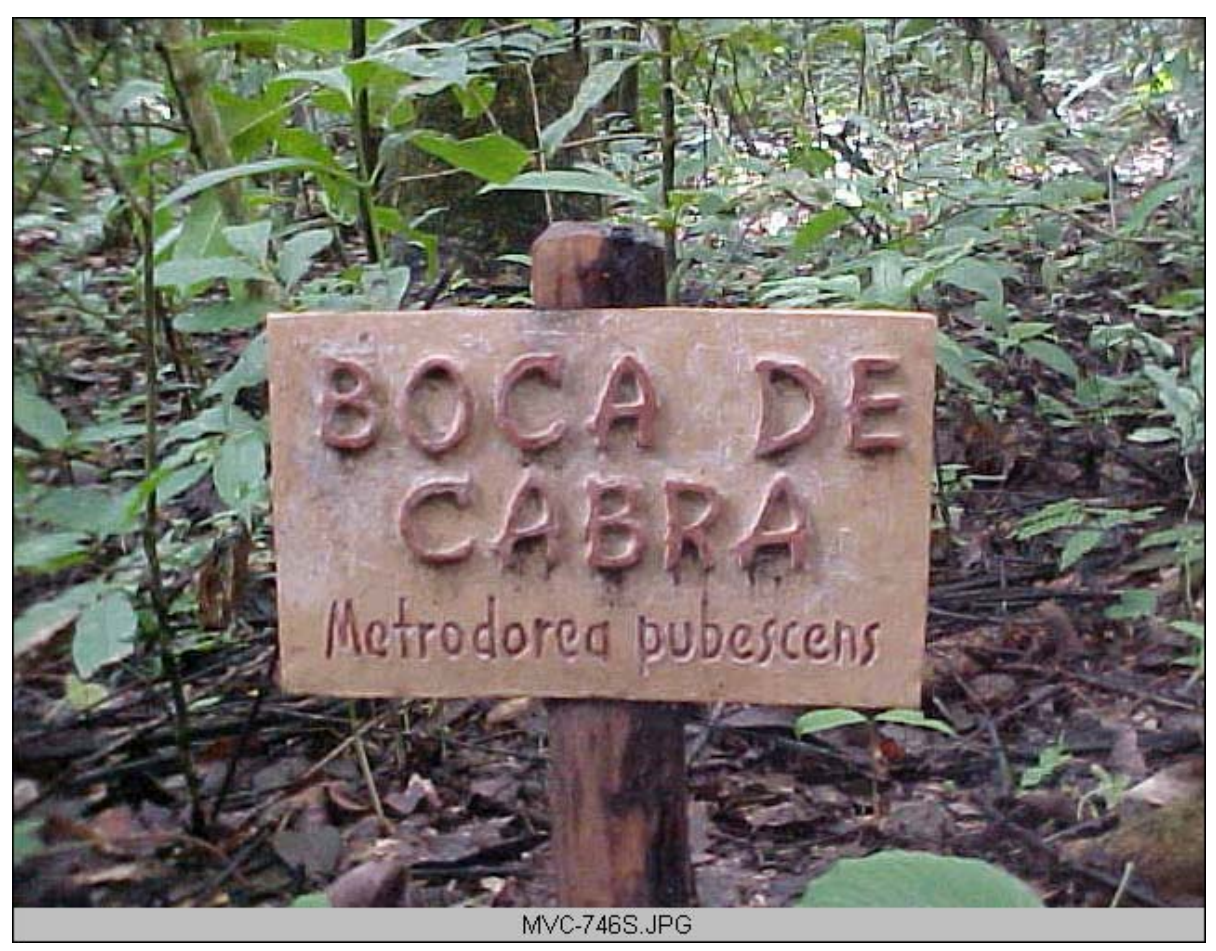

Placa de Identificação de espécies

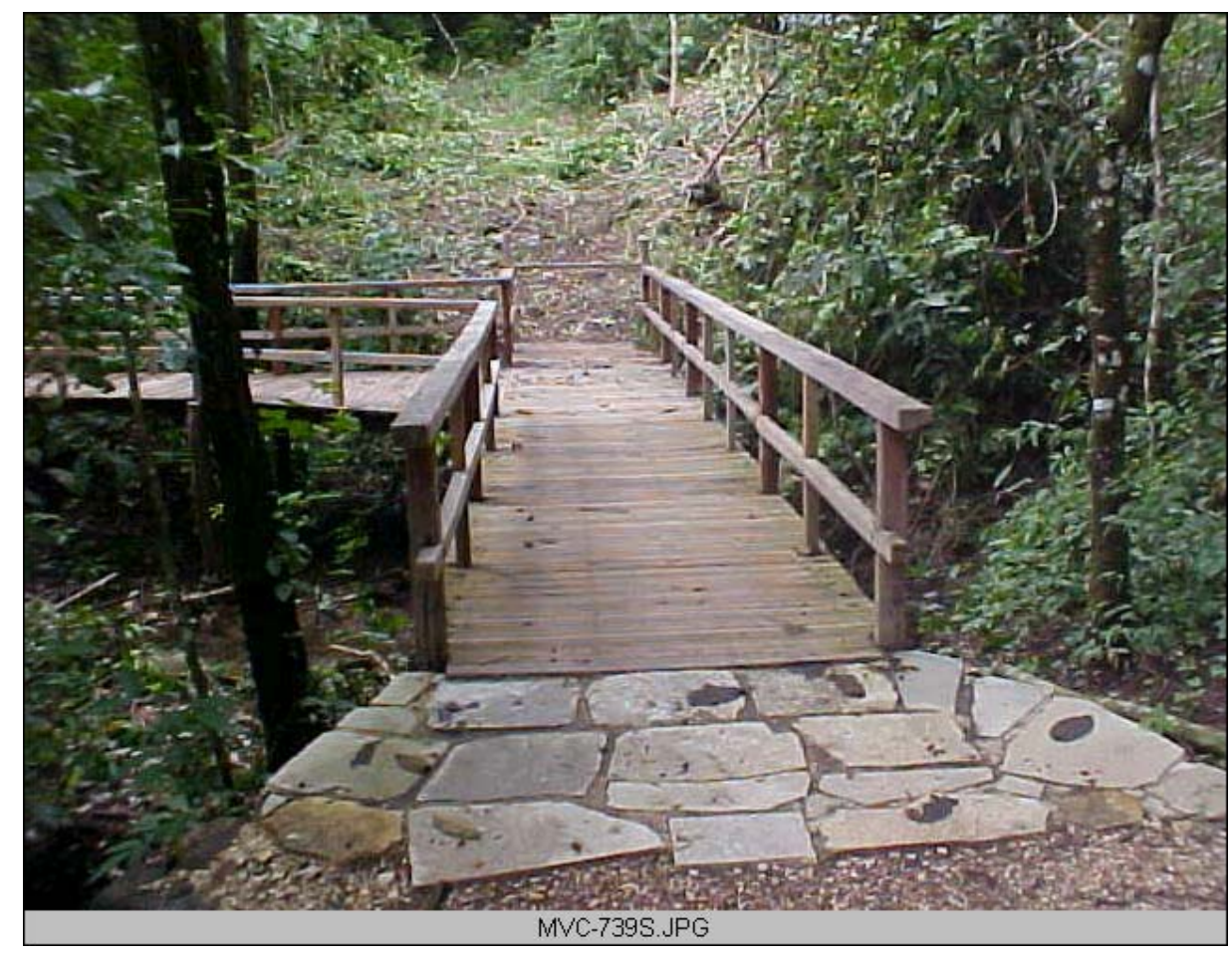

Trilha Suspensa 


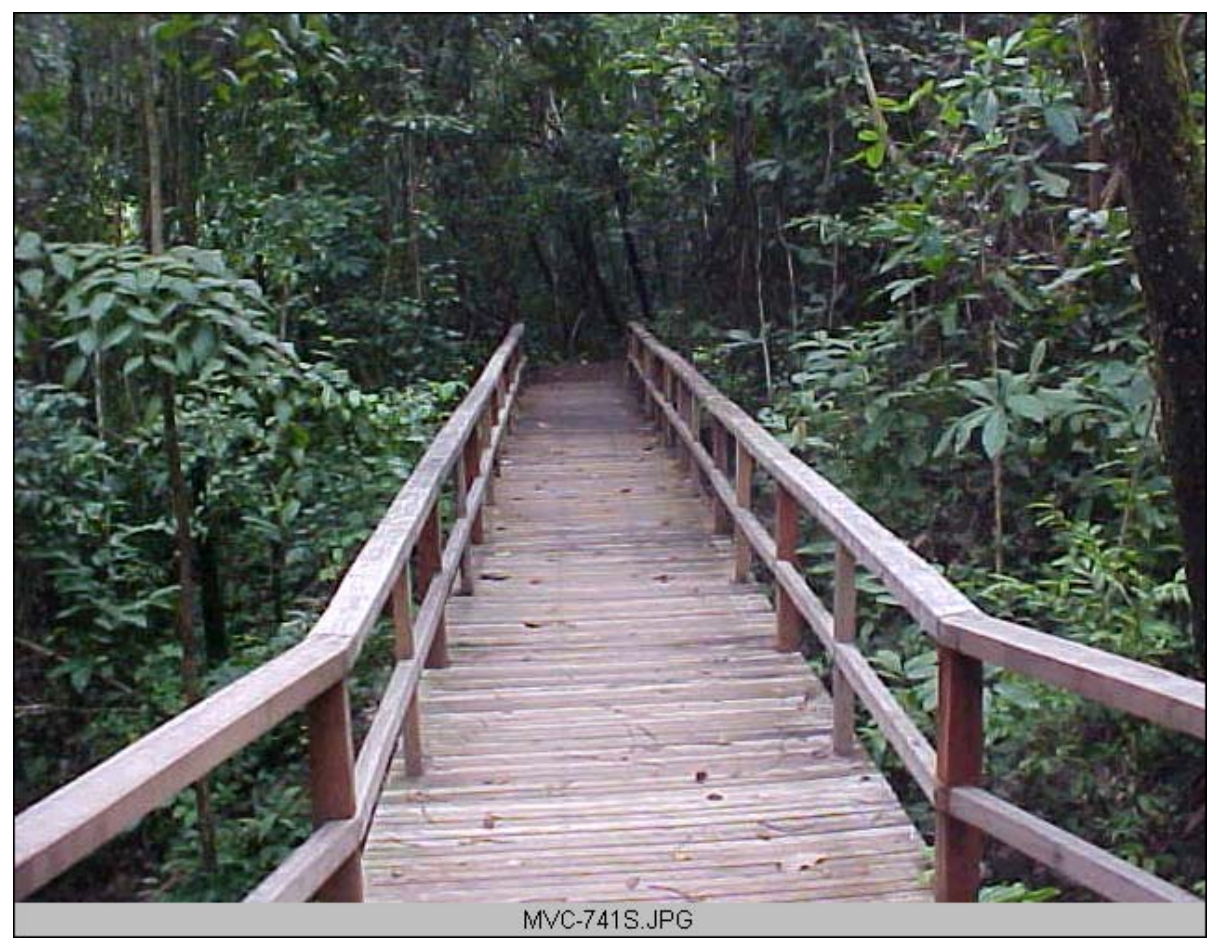

Trilha Suspensa

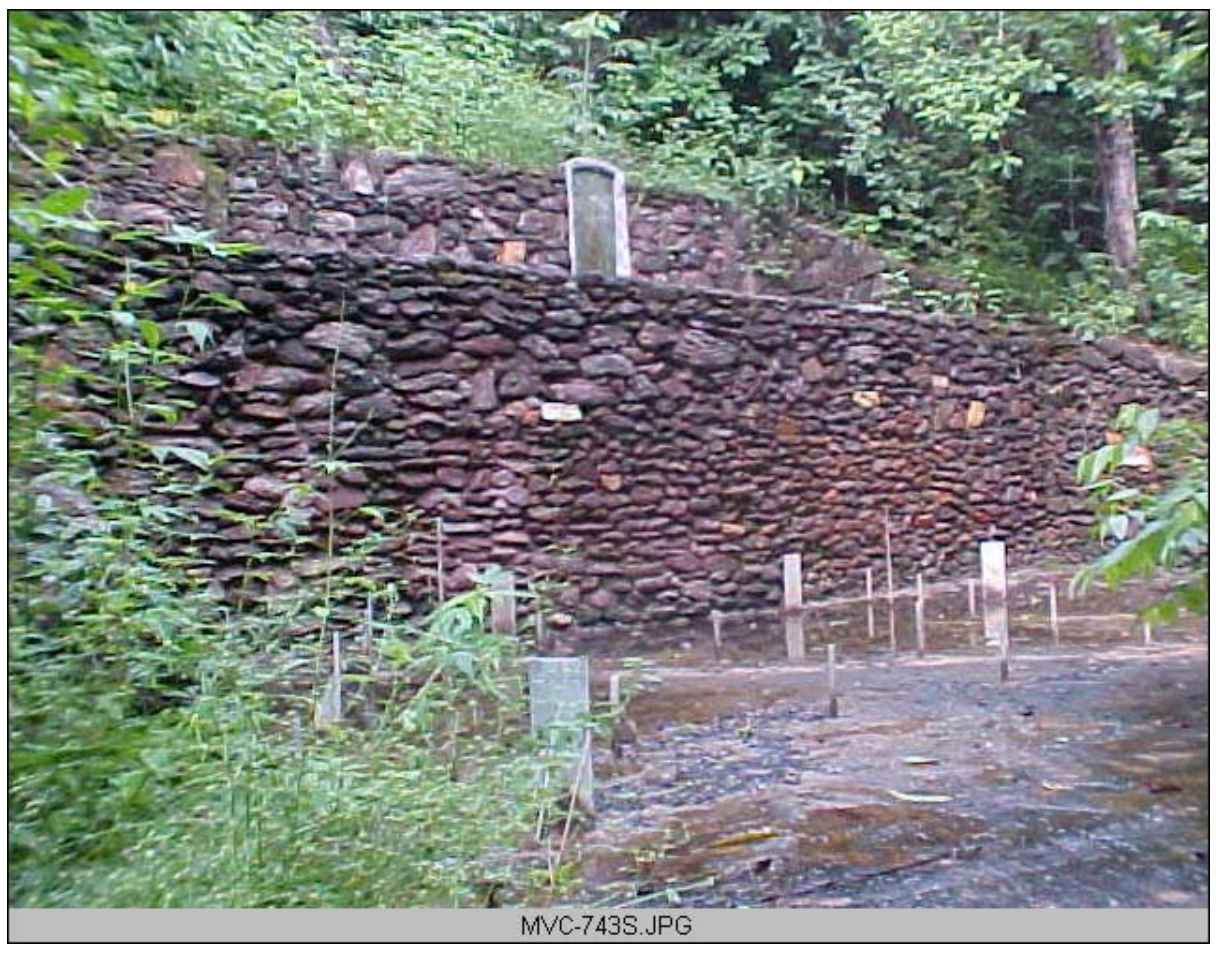

Base da Torre de Observação 


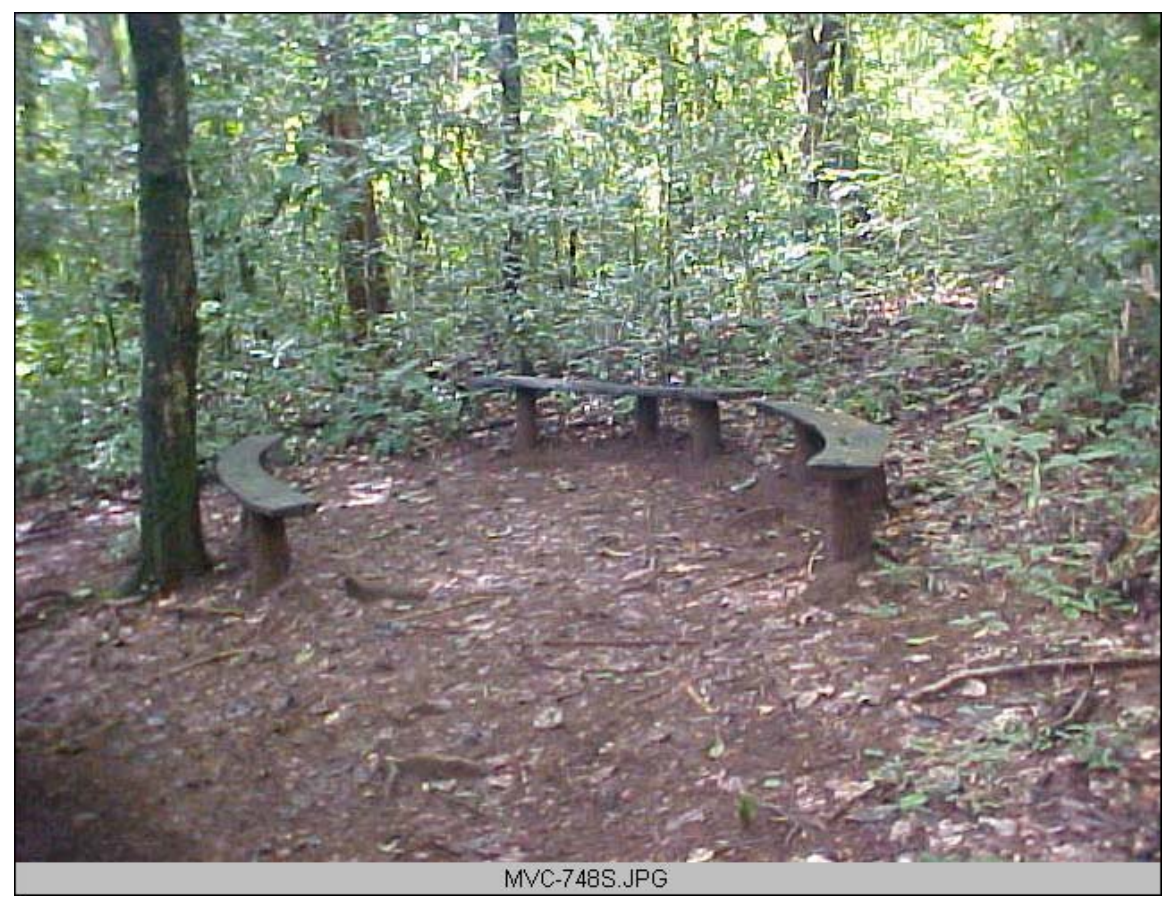

Espaço para descanso

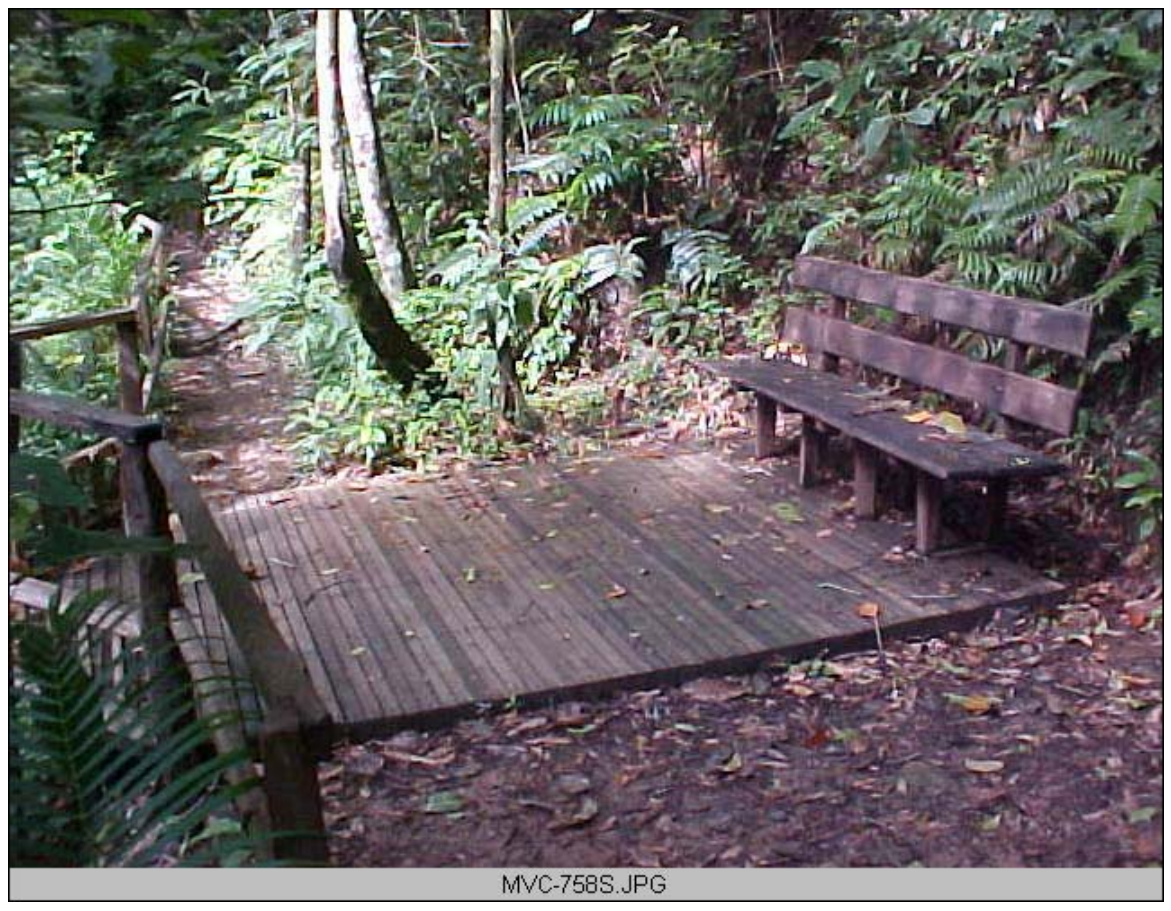

Banco em frente ao rio 


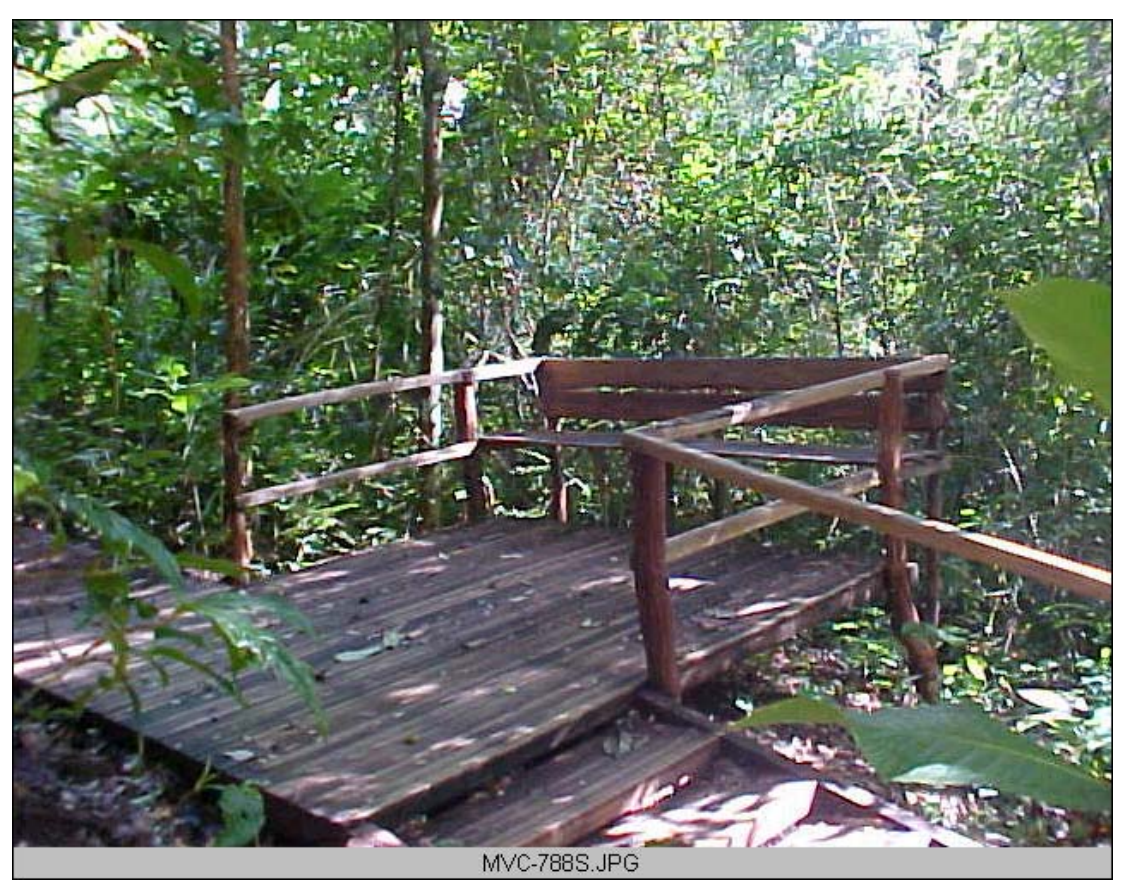

Banco na mata

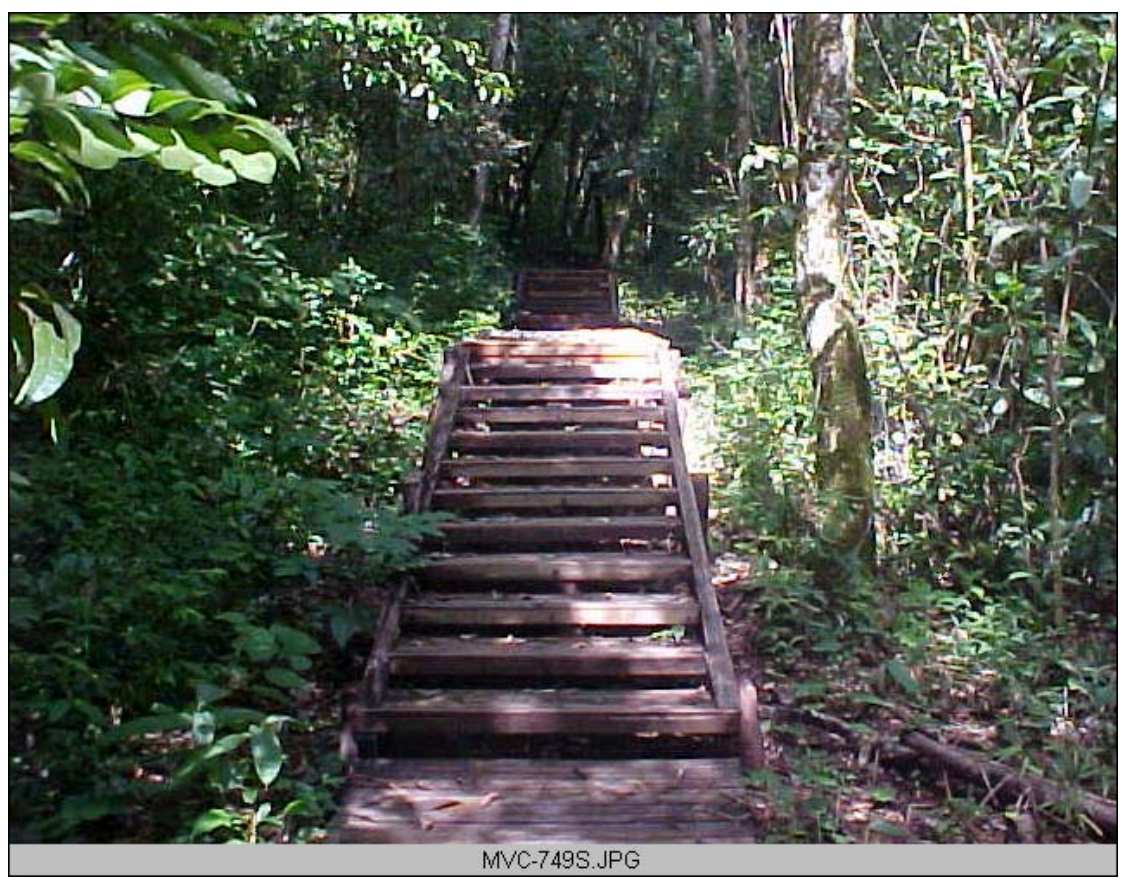

Escada em madeira 


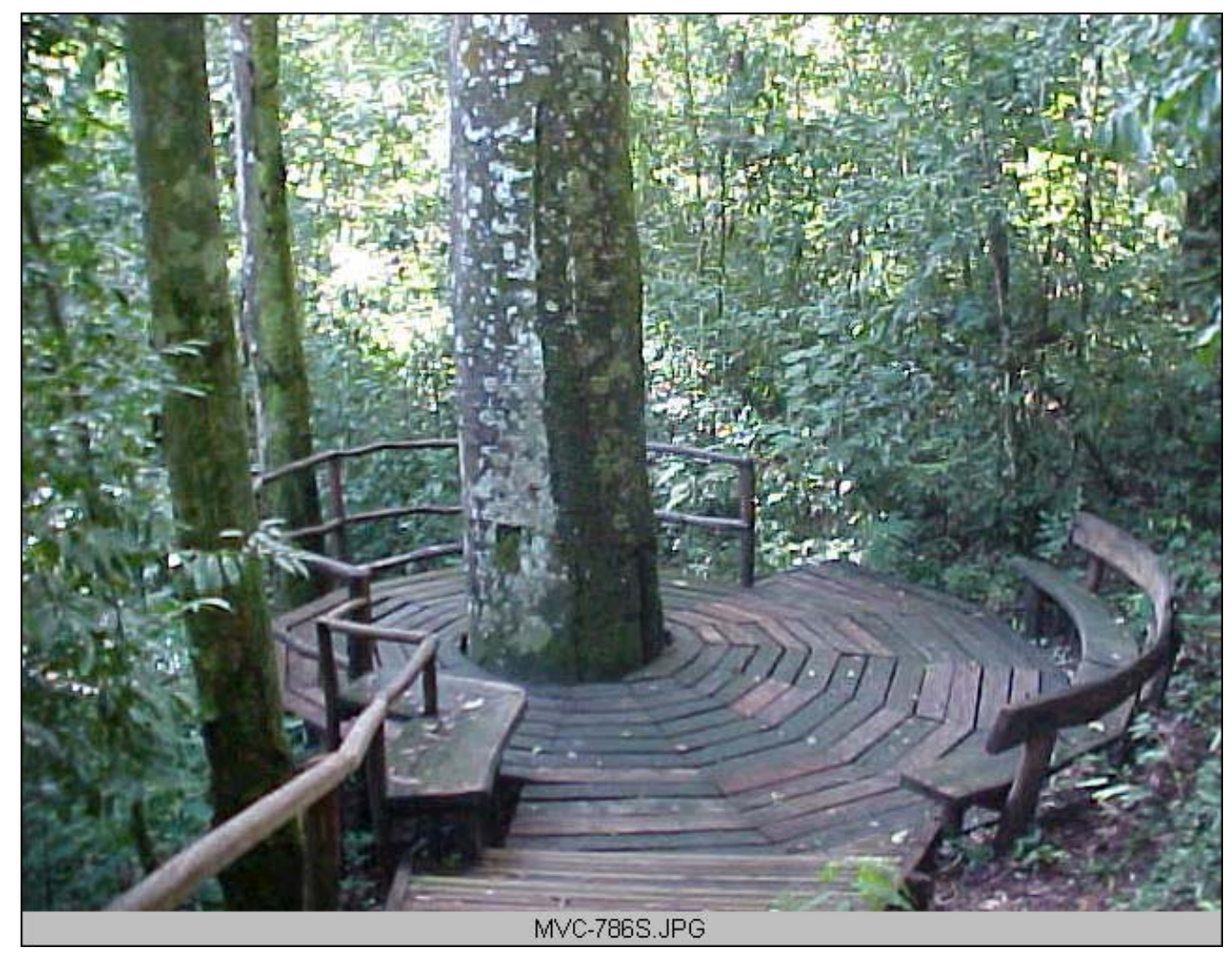

Jatobá " Mẫe da Floresta"

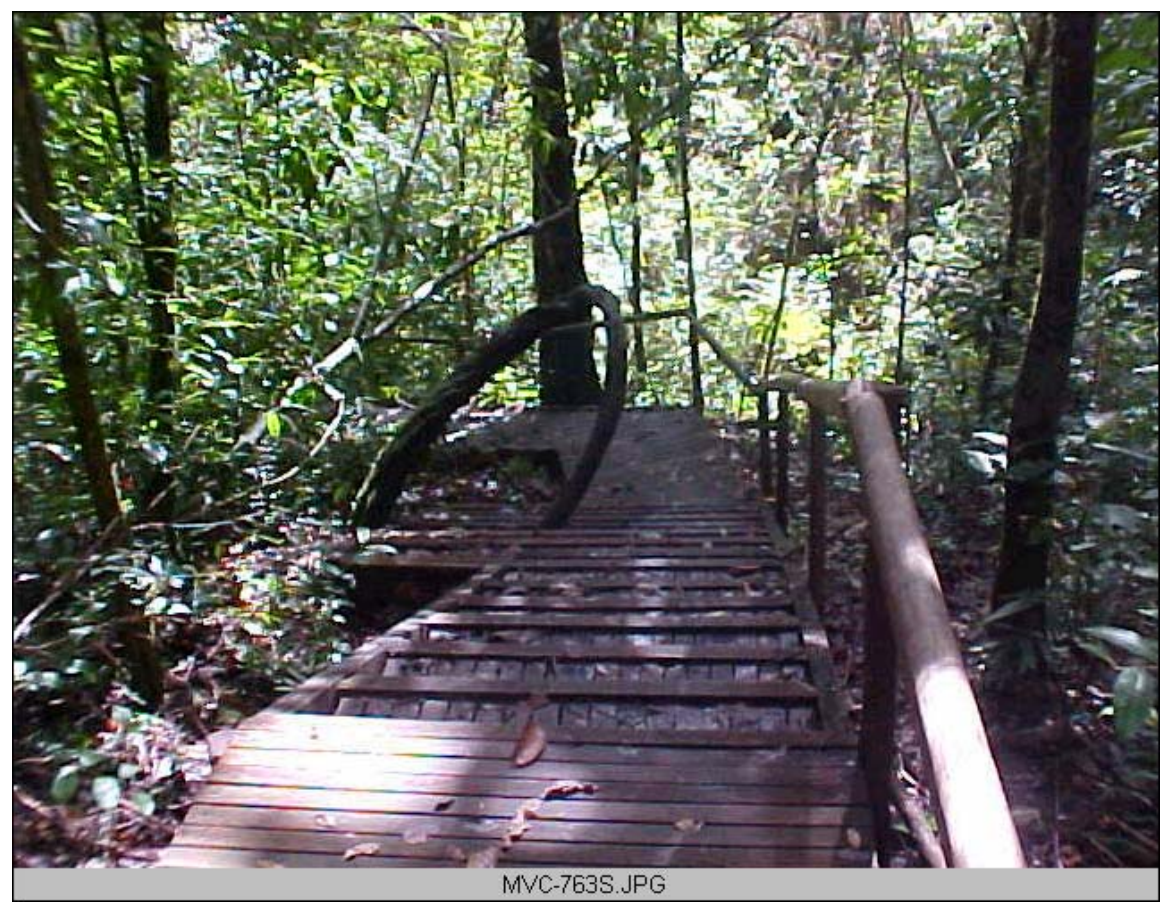




\section{Escada da raiz}

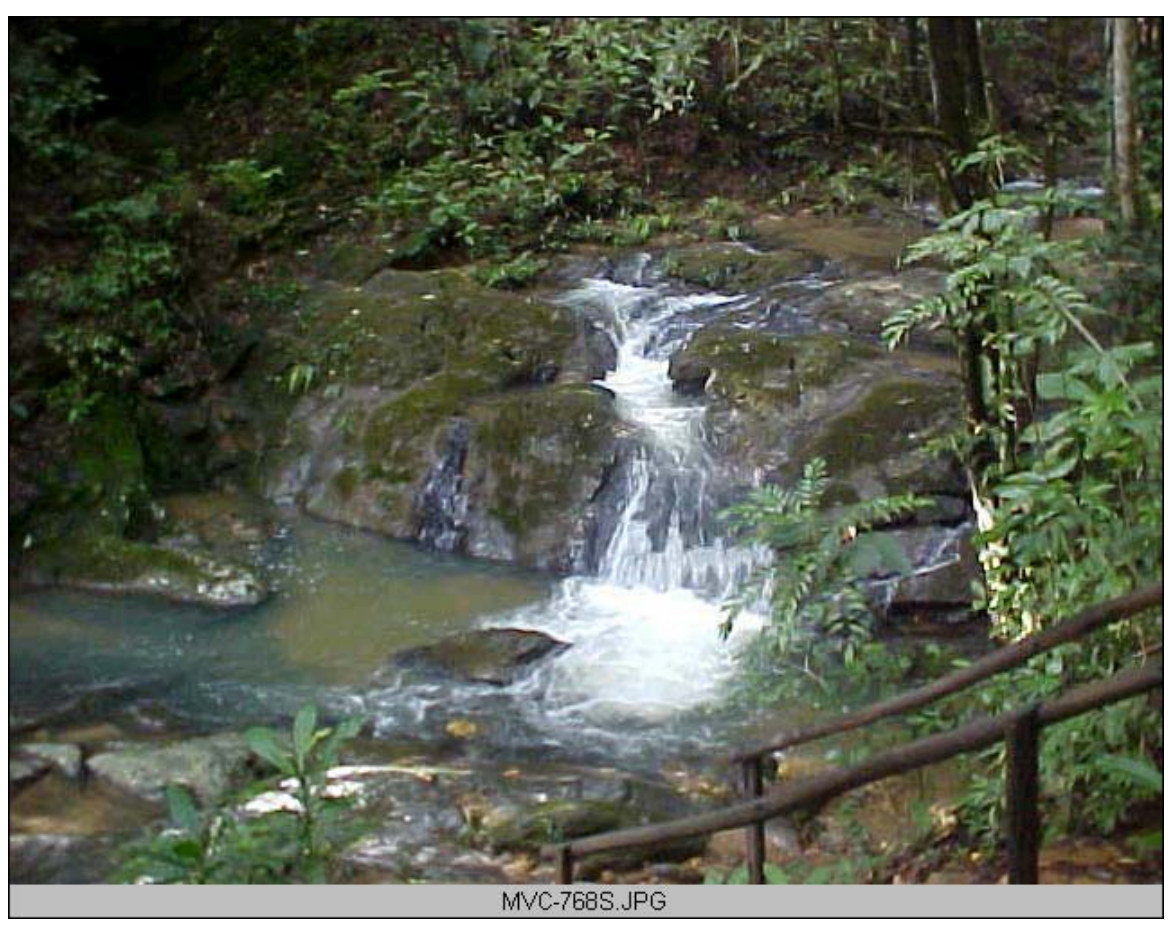

Rìo Vagafogo 


\section{Apêndice A - Roteiro de Entrevista}

Realizada com:

Como é o relacionamento com a comunidade? Existe algum tipo de cooperação entre a comunidade e a reserva?

A comunidade apóia a reserva? Que tipo de benefícios a reserva oferece para a comunidade?

Como é o contrato/convênio com a FUNATURA? Existe algum acordo com outras instituições?

Quando existe um problema na reserva, que tipo de apoio receba da instituição? Existe alguma estratégia pré-definida?

Existe troca de informações e experiências com outras reservas ou instituições? Como é feito?

Como você qualifica o apoio que recebe da FUNATURA? Qual o papel desse apoio para o manejo e gestão da reserva? E com as outras instituições?

Há quanto tempo existe esse apoio com cada instituição?

Sobre os recursos humanos, quantos funcionários você mantém na fazenda e quais as são funções? Existe algum tipo de política de incentivo e/ou reconhecimento dos funcionários?

Qual o salário dos funcionários? Existe algum diferencial por estarem em um projeto conservacionista?

Os funcionários têm autonomia nas funções que desempenham? Qual o nível de autoridade?

Seus funcionários estão atendendo às suas necessidades e de conservação da reserva?

Qual o nível de instrução do pessoal? Há quanto tempo trabalham na mesma função?

Como se comportam em relação ao trabalho que desempenham?

Você acha que a infra-estrutura que você possui está atendendo bem as necessidades de manejo da reserva (em termos de quantidade, funcionalidade e localização)? Qual é o estado de conservação da infra-estrutura?

O Plano de manejo já tem dez anos. Quantos por cento do Plano você acredita que foi executado? Existe algum plano anual de operação que ajude na execução do plano de manejo? Como é feito?

Como está a situação da zona recuperação? 
Sobre os programas de manejo, existe alguma atualização para esses programas? Qual o nível de execução?

Existe alguma atualização sobre as informações biofísicas e cartográficas da reserva?

Mudou alguma coisa? E as informações socioeconômicas?

Como é a área no entorno da reserva?

Como é feito o monitoramento da área? O que está estabelecido no Plano de Manejo está sendo feito, como formulário, etc?

Como as informações são utilizadas?

Sobre os usos atuais: Quais são os usos atuais?

Como é o seu fornecimento de água e o que é feito com os dejetos sólidos e líquidos (lixo e esgoto) da fazenda? 


\section{Apêndice B - Questionário complementar- SVS Vagafogo}

\section{Respondido por:}

Qual a nacionalidade dos proprietários?

Quem faz a gestão da reserva?

Numa escala de 0 a 4, avalie as razões para o estabelecimento da reserva:

\begin{tabular}{|l|l|l|l|l|l|}
\hline & $\begin{array}{c}0 \text { - Sem } \\
\text { importância }\end{array}$ & 1 & 2 & 3 & $\begin{array}{c}4 \text { - Super } \\
\text { importante }\end{array}$ \\
\hline Turismo natural & & & & & \\
\hline $\begin{array}{l}\text { Preservação de uma } \\
\text { espécie ou habitat em } \\
\text { particular }\end{array}$ & & & & & \\
\hline Pesquisa Científica & & & & & \\
\hline Educação & & & & & \\
\hline $\begin{array}{l}\text { Desenvolvimento } \\
\text { comunitário }\end{array}$ & & & & & \\
\hline Conservação & & & & & \\
\hline Residência pessoal & & & & & \\
\hline $\begin{array}{l}\text { Proteção do IBAMA/ } \\
\text { poder de polícia }\end{array}$ & & & & & \\
\hline
\end{tabular}

Das atividades educacionais e de recreação oferecidas pela reserva (trilhas, observação de pássaros, etc) por favor, liste em ordem de importância as tre (3) mais populares atividades praticadas pelo visitante:

Quais características especiais da sua reserva, como um animal específico ou ambiente natural, você acha que atrai mais os visitantes?

Que tipo de atividades a reserva está oferecendo?

Que tipo de serviços a reserva está providenciando?

Qual o número de visitantes que recebe:

*Por dia: $\quad$ *Por mês: *Por ano:

Qual tem sido o crescimento anual em números de visitantes e qual sua expectativa para os próximos 5 anos?

Quantos por cento dos visitantes são estrangeiros?

Qual a média de gasto por visitante por dia?

Qual é o valor da entrada? Existe diferença de preço para brasileiros e estrangeiros? E para pessoas da comunidade? 
Quais os meses de alta estação para o turismo?

Dos empregados permanentes da reserva, quantos são locais?

\section{Quantos temporários ou ocasionais? Na baixa estação e na alta estação?}

Quantos por cento da rentabilidade da fazenda são provenientes da receita com o turismo?

No ano passado, que percentagem dos gastos operacionais da reservas foram provenientes de:

- lucro do turismo

- rebanho e agricultura

- donotivos

- fundos do governo

- fundos de fonte privada

- empréstimo do governo

- empréstimo de fonte privada

- investidor

- outros: brunch e produtos artesanais

- total:

No ano passado o lucro da reserva superou os gastos? Há quantos anos vem sendo assim?

Que porcentagem do excedente foi reinvestida na reserva?

A reserva possui algum contrato formal com instituições governamentais e não governamentais para administrar a reserva? Como é o acordo?

A reserva possui algum biólogo ou cientista na equipe?

Qual é ou qual foi a importância do Plano de Manejo para a reserva?

Sua reserva possui alguma publicação?

Por favos, indique aproximadamente o valor corrente para a reserva e a infra-estrutura.

A reserva recuperou o investimento inicial?

Quantos anos levaram ou vai levar para recuperar o investimento?

Quais dos incentivos governamentais e não-governamentais foram importantes na decisão de estabelecer a reserva?

Você teve algum problema na criação da reserva e implantação da atividade turística? Que atitudes tomou para resolvê-los? Qual foi o seu grau de sucesso?

A reserva faz fronteira com algum parque ou reserva pública ou privada? Quais?

Qual a porcentagem das atividades turísticas dos seus visitantes ocorrem nas áreas protegidas 
adjacentes?

Qual a importância das áreas protegidas adjacentes na atração de turistas para sua reserva?

A reserva oferece algum serviço para a área vizinha? Qual? Explique.

Indique se algum desses itens se mostrou ou tem se mostrado como um problema para a reserva e em que grau numa escala de $0-4$ :

\begin{tabular}{|l|l|l|l|l|l|}
\hline \multicolumn{1}{|c|}{ Problemas } & $\begin{array}{c}0-\text { Sem } \\
\text { problema }\end{array}$ & 1 & 2 & 3 & $\begin{array}{c}4 \text { - Problemas } \\
\text { graves }\end{array}$ \\
\hline Caça ilegal & & & & & \\
\hline Posseiros & & & & & \\
\hline $\begin{array}{l}\text { Derrubada de arvores / } \\
\text { extração de lenha }\end{array}$ & & & & & \\
\hline $\begin{array}{l}\text { Oposição da comunidade ao } \\
\text { turismo }\end{array}$ & & & & & \\
\hline Inquietação política no país & & & & & \\
\hline Orçamento deficiente & & & & & \\
\hline $\begin{array}{l}\text { Falta de cooperação } \\
\text { governamental }\end{array}$ & & & & & \\
\hline Outros: & & & & & \\
\hline
\end{tabular}




\title{
Apêndice C -
}

\author{
Lista de âmbitos, variáveis, sub-variáveis e parâmetros para a avaliação da \\ efetividade de manejo do Santuário de vida Silvestre Vagafogo
}

\subsection{1. Âmbito LEGAL, variável POSSE DA TERRA, sub-variável DOMINIO LEGAL}

A reserva possui o domínio legal sobre a terra.

\subsection{2. Âmbito LEGAL, variável POSSE DA TERRA, sub-variável CONFLITOS PELA POSSE}

Não existe conflito pela posse da terra

Existe conflito pela posse da terra.

\section{2. Âmbito LEGAL, variável LEGISLAÇÃO AMBIENTAL}

Existe um conjunto de leis gerais que tratam da conservação da natureza, abrangendo todos os níveis possíveis. O complexo de leis é muito claro e garante o bom uso e aproveitamento dos recursos naturais.

Existe o complexo legal citado acima, mas existem lacunas específicas que não chegam a afetas

o manejo e a proteção da área 3

Existe um complexo de leis sobre o uso e aproveitamento dos recursos naturais, com algumas lacunas especificas e ligeiras superposições entre leis.

Existem algumas leis que buscam assegurar a conservação dos recursos naturais, mas com marcante conflito entra as mesmas, o que prejudica o manejo da área. ...................................... 1 Não se conta com leis gerais que normatizem o uso e o aproveitamento dos recursos naturais ....... 0

\section{3. Âmbito LEGAL, variável RECONHECIMENTO DA ÁREA}

O instrumento jurídico que reconhece a proteção da área já se aplica a reserva a mais de cinco anos.

O instrumento jurídico que reconhece a proteção da área se aplica a reserva a menos de um

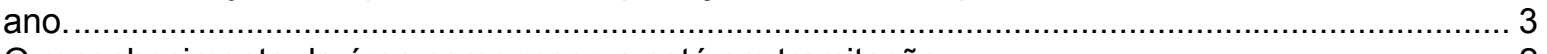

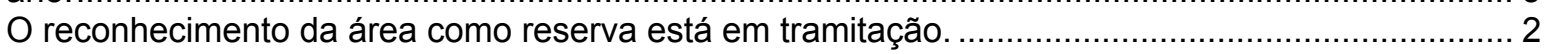

O proprietário tem interesse em reconhece a área como área de conservação. ............................... 1

O proprietário não tem interesse em reconhece a área como área de conservação ........................... 0

\section{1. Âmbito POLITICO, variável APOIO DA COMUNIDADE}

O apoio da comunidade é inquestionável. Existe um amplo reconhecimento do papel da reserva. A reserva gera muitos benefícios para a comunidade.

Existe um reconhecimento mediano do valor intrínseco da área, mas o apoio da comunidade não é claro. A reserva gera alguns benefícios para a comunidade.

Não existe um reconhecimento do papel e importância da reserva para a comunidade, mas não existe oposição a reserva.......

Não existe reconhecimento do papel e valor da reserva e existe oposição para sua permanência..... 


\subsection{1 Âmbito POLÍTICO, variável APOIO INSTITUCIONAL, sub-variável CLAREZA DE JURISDIÇÃO E ATRIBUIÇÕES}

Existe um convenio ou acordo formal entre a reserva e outras instituições que estabelece claramente a jurisdição e os papeis da cada uma .................................................................. 4 Existe um acordo formal, mas há brechas que eventualmente geram duvidas sobre o papel de cada instituição.

O que existe é um acordo informal entre as partes, e cada tarefa é tratada em separado.

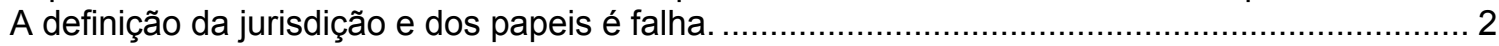

Não existe convênios nem acordos informais, e a cooperação entre a reserva e outras instituições é muito esporádica.

Não existe cooperação

\subsection{2 Âmbito POLÍTICO, variável APOIO INSTITUCIONAL, sub-variável COORDENAÇÃO DE ATIVIDADES PARA A SOLUÇÃO DE PROBLEMAS}

Existe coordenação para solucionar problemas e estes são resolvidos de maneira eficaz e eficiente, mediante uma estratégia definida. 4

Existe coordenação para solucionar problemas, mas sem estratégias definidas. A coordenação é esporádica mas é eficiente.

A coordenação institucional para solucionar problemas é esporádica e pouco eficiente.................... 2 Não existe coordenação de atividade, somente atos isolados dês ambas as partes

para solucionar os problemas que afetam as reservas.

Não há nenhum tipo de cooperação e os problemas de acumulam sem solução . ........................ 0

\subsection{3. Âmbito POLÍTICO, variável APOIO INSTITUCIONAL, sub-variável INTERCAMBIO DE INFORMAÇÕES E EXPERIÊNCIAS}

O intercambio de informações e experiências entre a reserva e outras instituições é permanente e se baseia em estratégias previamente definidas....

Existe um intercambio de informações e experiências, mas este se dá eventualmente e sem definição de estratégias

O intercambio de informações só ocorre em reuniões ou através de publicações de

Resultados

O intercambio de informações e experiências é quase inexistente.

Não há nenhum tipo de intercambio.

\subsection{4. Âmbito POLÍTICO, variável APOIO INSTITUCIONAL, sub-variável ALCANCE}

O apoio institucional é fundamental para a gestão da reserva. Alcance muito elevado.

O apoio institucional é importante mas não é fundamental para a gestão da reserva. Alcance elevado.

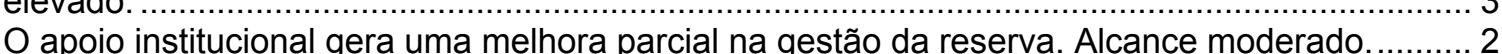

$\mathrm{O}$ apoio institucional tem pouca influencia na gestão da reserva. Alcance baixo ........................... 1

$\mathrm{O}$ apoio institucional não exerce influencia na gestão da reserva. Alcance muito baixo ................ 0

\subsection{5. Âmbito POLÍTICO, variável APOIO INSTITUCIONAL, sub-variável ESTABILIDADE}

O apoio se mantém a mais de cinco anos. Estabilidade muito alta. ............................................. 4

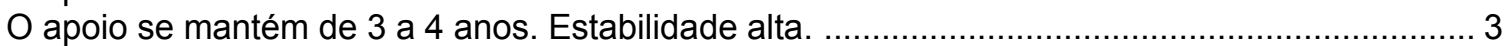

$\mathrm{O}$ apoio se mantém a mais de dois anos. Estabilidade moderada. .......................................... 2

$\mathrm{O}$ apoio se mantém a mais de 1 ano. Estabilidade baixa. ........................................................ 1

$\mathrm{O}$ apoio existe a menos de 1 ano. Estabilidade muito baixa. ................................................ 0 


\subsection{1. Âmbito POLÍTICO, variável RECURSOS HUMANOS, sub-variável INCENTIVO AO BOM RENDIMENTO}

Existe uma política de incentivo e reconhecimento dos funcionários, que estimula a permanência no serviço e estabelece animo para o trabalho. 4

Não há uma política definida de incentivos, mas há reconhecimento dos progressos e realizações dos funcionários no desenvolvimento de suas funções

Os incentivos ao bom rendimento dos funcionários são poucos, mas há um desejo dos

proprietários para incrementar esses incentivos.

Os incentivos ao bom rendimento dos funcionários são eventuais, dependendo da vontade do gerente/proprietário.

Não existem incentivos nem reconhecimento dos funcionários.

\subsection{2. Âmbito POLÍTICO, variável RECURSOS HUMANNOS, sub-variável SALÁRIOS}

Os salários estão $60 \%$ ou mais acima dos praticados na região, para funções e responsabilidades similares.

Os salários estão entre $40 \%$ e $60 \%$ acima do que ocorre na região, para funções e responsabilidades similares.

Os salários estão entre $20 \%$ e $40 \%$ acima do que ocorre na região, para funções e responsabilidades similares.

Os salários estão entre 105 e $20 \%$ acima do que ocorre na região, para funções e responsabilidades similares.

Os salários estão no mesmo nível ou abaixo do que ocorre na região, para funções e

responsabilidades similares.

\subsection{3. Âmbito POLÍTICO, variável RECURSOS HUMANNOS, sub-variável CAPACITAÇÃO}

Existe um programa de capacitação dos funcionários que é cumprido de maneira eficiente e assegura a especialização do pessoal.

Existe um programa de capacitação que não está sendo cumprido em sua totalidade, mas os funcionários recebem uma cota de treinamento satisfatória.

Não existem atividades de capacitação, mas os funcionários recebem um pequeno treinamento e informações relevantes para o cumprimento dos objetivos de manejo da área.

Existe uma iniciativa da reserva ou do administrados de implementar um plano de capacitação ou treinamento.

Não existe capacitação nem perspectivas de implementação à curto prazo.

\subsection{4. Âmbito POLÍTICO, variável RECURSOS HUMANNOS, sub-variável AUTORIDADE DOS FUNCIONÁRIOS}

Não existe dúvida da autoridade dos funcionários e estas se ajustam aos objetivos de gestão da área.

Os funcionários possuem a autoridade necessária para o desenvolvimento de suas funções, mas existe a necessidade de ajustá-las aos objetivos de gestão da área.

Os funcionários possuem algum nível de autoridade, mas esta não se encontra devidamente clara com os regulamentos.

Os funcionários encontram muitos problemas para impor sua autoridade no desenvolvimento de suas funções.

Os funcionários não têm nenhuma autoridade.

\subsection{1. Âmbito ADMINISTRATIVO, variável PESSOAL, sub-variável QUANTIDADE}

A quantidade de pessoal presente representa $90 \%$ ou mais do necessário. 
A quantidade de pessoal presente está entre $36 \%$ e $59 \%$ do necessário.

\subsection{2. Âmbito ADMINISTRATIVO, variável PESSOAL, sub-variável NíVEL DE INSTRUÇAO - GERENTE}

Nível superior. 4

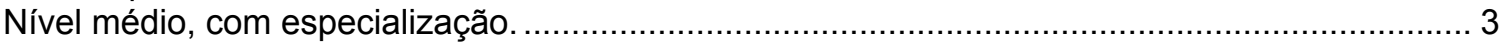

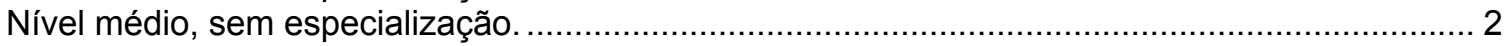

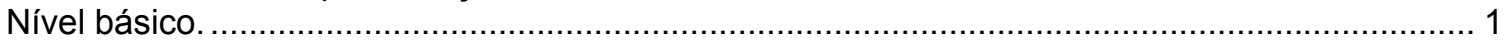

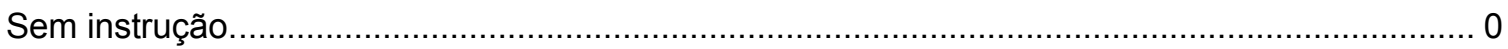

\subsection{2. Âmbito ADMINISTRATIVO, variável PESSOAL, sub-variável NÍVEL DE INSTRUÇÃO - PESSOAL DE APOIO}

Nível superior.

Nível médio, com especialização.

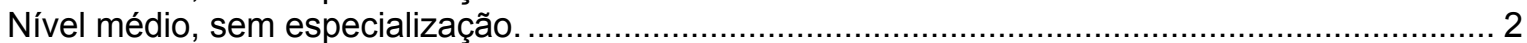

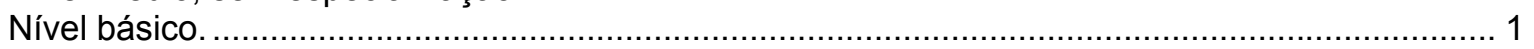

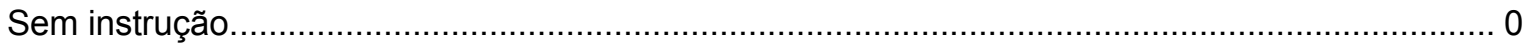

\subsection{3. Âmbito ADMINISTRATIVO, variável PESSOAL, sub-variável EXPERIÊNCIA NA FUNÇÃO - GERÊNCIA}

O funcionário está a mais de dez anos trabalhando na mesma função ou em funções similares 4

O funcionário está a mais de 7 e menos de 10 anos trabalhando na mesma função ou em funções similares

O funcionário tem a mais de 4 e menos de 7 anos trabalhando na mesma função ou em funções similares

O funcionário está a mais de 1 e menos de 4 anos na mesma função ou em funções similares.... 1

O funcionário está trabalhando a menos de um ano na mesma função ou funções similares. ...... 0

\subsection{3. Âmbito ADMINISTRATIVO, variável PESSOAL, sub-variável EXPERIÊNCIA NA FUNÇÃO - PESSOAL DE APOIO}

O funcionário está a mais de dez anos trabalhando na mesma função ou em funções similares ... 4 O funcionário está a mais de 7 e menos de 10 anos trabalhando na mesma função ou em

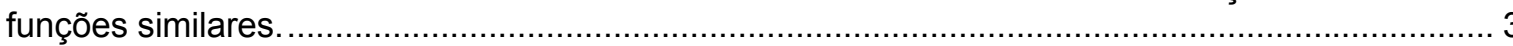

O funcionário tem a mais de 4 e menos de 7 anos trabalhando na mesma função ou em

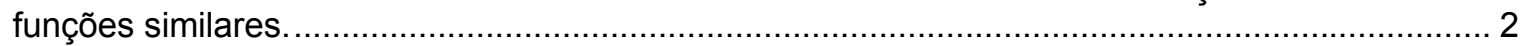
O funcionário está a mais de 1 e menos de 4 anos na mesma função ou em funções similares.. . 1

O funcionário está trabalhando a menos de um ano na mesma função ou funções similares ....... 0

\subsection{4. Âmbito ADMINISTRATIVO, variável PESSOAL, sub-variável MOTIVAÇÃO}

O funcionário responde com entusiasmo ao trabalho e está contente com as condições de trabalho...... 4

O funcionário sabe e sente a importância de seu trabalho e o executa com dedicação, mas sente falta de algumas condições de trabalho que são fáceis de ser alcançadas.

O empregado executa suas tarefas normalmente, mas com sentimento geral de insatisfação quanto às condições de trabalho.

O empregado possui pouco entusiasmo ou motivação e se sente abandonado e pouco

valorizado pela administração

O empregado não apresenta nenhum entusiasmo ou motivação para o trabalho 


\subsection{1. Âmbito ADMINISTRATIVO, variável INFRA-ESTRUTURA, sub-variável QUANTIDADE}

A quantidade atual representa $90 \%$ ao mais da requerida.......................................................... 4

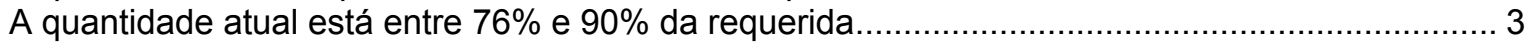

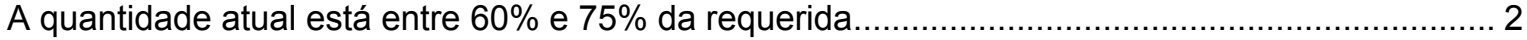

A quantidade atual está entre $36 \%$ e $59 \%$ da requerida.............................................................. 1

A quantidade atual representa menos de $35 \%$ da requerida................................................... 0

\subsection{2. Âmbito ADMINISTRATIVO, variável INFRA-ESTRUTURA, sub-variável ESTADO DE CONSERVAÇÃO}

A construção ou facilidade se encontra em perfeitas condições de uso e existe uma manutenção adequada da mesma

A construção ou facilidade se encontra em boas condições, mas existem problemas na sua

manutenção.

A construção ou facilidade possui um estado regular que está gerando problemas em seu uso.... 2

O estado de conservação da construção ou facilidade está ruim, apresentando muitas

dificuldades para o seu uso.

O estado de conservação da construção ou facilidade é tal que não permite seu uso.

\subsection{3. Âmbito ADMINISTRATIVO, variável INFRA-ESTRUTURA, sub-variável LOCALIZAÇÃO}

A construção ou facilidade se encontra no local mais adequado para seu uso ou fim, e o acesso a mesma se dá sem nenhum problema

A construção ou facilidade se encontra no local mais adequado para seu uso ou fim, mas

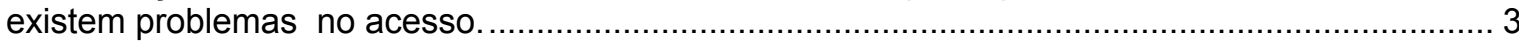

A construção ou facilidade não se encontra no melhor local, contudo não se apresentam conflitos de uso.

A construção ou facilidade não está localizada no lugar adequado e existem alguns conflitos de uso devido a isso......

A construção ou facilidade não se encontra no lugar adequado e isso está gerando muitos conflitos ou dificuldades para seu uso.

\subsection{4. Âmbito ADMINISTRATIVO, variável INFRA-ESTRUTURA, sub-variável FUNCIONALIDADE}

A construção ou facilidade está adequada ao seu uso e sua importância é clara quanto ao manejo da reserva

A construção ou facilidade está adequada ao seu uso, mas está sendo compartilhada com

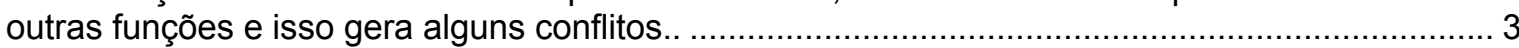

A construção ou facilidade está adequada ao seu uso, mas, por estar sendo compartilhada com outras funções, gerando conflito, está perdendo sua funcionalidade ................................... 2 A funcionalidade da construção ou facilidade precária devido a conflitos de uso existentes............ 1 A construção ou facilidade não é utilizada para o fim a que se propõe ........................................... 0

\subsection{1. Âmbito PLANEJAMENTO, variável PLANO DE MANEJO, sub-variável EXISTÊNCIA E ATUALIZAÇÃO}

Existe um plano de manejo elaborado ou revisado com menos de 5 anos ou em processo de elaboração ou revisão.

Existe um plano de manejo com mais de 5 anos, sem revisão.

O que existe é um plano de manejo com mais de 10 anos e está muito desatualizado.....

Não existe um plano de manejo para a área nem perspectiva para a elaboração de um. ............... 0 


\subsection{2. Âmbito PLANEJAMENTO, variável PLANO DE MANEJO, sub-variável EQUIPE DE PLANJAMENTO}

Existe uma equipe multidisciplinar que fez ou está fazendo o plano de manejo. 4

A equipe que fez ou está fazendo o plano de manejo não é multidisciplinar, mas conta com o apoio de diferentes técnicos....................................................................................... 3

O plano de manejo foi ou está sendo feito por uma pessoa, com o apoio de diferentes técnicos.. 2 A equipe técnica equipe fez ou esta fazendo o plano de manejo não é multidisciplinar e não conta com apoio técnico algum.

O plano de manejo está sendo feito por uma pessoa sem o apoio de técnicos.

\subsection{3. Âmbito PLANEJAMENTO, variável PLANO DE MANEJO, sub-variável NÍVEL DE EXECUÇÃO DO PLANO}

Plano executado em $90 \%$ ou mais do planejado e proposto. 4

Nível de execução entre $76 \%$ e $89 \%$ do planejado ............................................................. 3

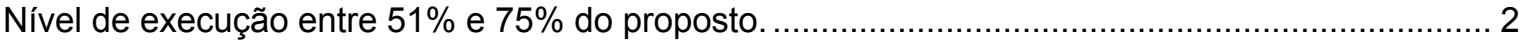

Só se conseguiu executar entre $36 \%$ e $50 \%$ do planejado............................................................ 1

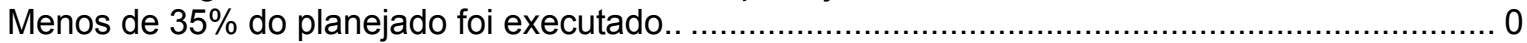

\subsection{4. Âmbito PLANEJAMENTO, variável PLANO DE MANEJO, sub-variável NÍVEL DE PLANEJAMENTO}

Todos os programas ou atividades desenvolvidas no local possuem seus planos específicos, sob os delineamentos gerais de um Plano de Manejo. Estes planos específicos se integram com os Planos Operacionais anuais da área.

A área conta com um Plano de Manejo como especificado acima, mas não existe Plano

Operacional anual

A área possui um Plano de Manejo, mas apenas com alguns documentos que podem ser considerados como delineadores para algumas atividades

A reserva possui apenas o Plano Operativo, sem um plano geral. ........................................... 1

Não existe nenhum instrumento de planejamento na área.

\subsection{5. Âmbito PLANEJAMENTO, variável PLANO DE MANEJO, sub-variável ZONEAMENTO}

Existe um sistema de zoneamento definido, cujo desenho incorpora conhecimento científico e conceitos técnicos atualizados. Existe uma regulamentação de uso estabelecida e os empregados e usuários da área conhecem e respeitam estas regras .......................................... 4 Existe um sistema de zoneamento definido segundo as condições apresentadas acima, mas o nível de conhecimento do mesmo pelos empregados e usuários é baixo............................. 3 O zoneamento existente já não se adapta totalmente a realidade da área e precisa passar (ou está passando) por uma revisão.

O zoneamento proposto para a área é muito inadequado com a realidade, ademais é pouco reconhecido ou aceito entre os empregados e usuários. As normas de uso não são apropriadas para as atividades atuais.

Não existe nenhum tipo de zoneamento.

\subsection{1. Âmbito PROGRAMAS DE MANEJO, variável SUBPROGRAMA DE PROTEÇÃO, sub- variável EXISTÊNCIA E ATUALIDADE}

Existe um programa de manejo específico para a atividade, elaborado ou revisado com menos de 5 anos

A reserva está passando por um processo de elaboração oi revisão deste programa.

Existe um programa especifico, mas com mais de 5 anos de existência, sem revisão.

O que existe é um programa com amais de 10 anos de existência e que está muito desatualizado. 
Não existe um programa de manejo especifico para esta componente, nem perspectivas para elaboração de um.

\subsection{2. Âmbito PROGRAMAS DE MANEJO, variável SUBPROGRAMA DE PROTEÇÃO, sub- variável NÍVEL DE EXECUÇÃO}

Programa executado em $90 \%$ ou mais do proposto. 4

Nível de execução entre $76 \%$ e $89 \%$ do planejado. ............................................................ 3

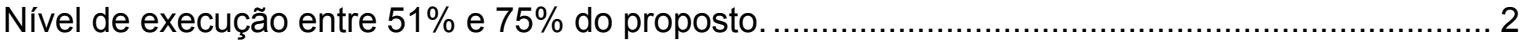

Só se conseguiu executar entre $36 \%$ e $50 \%$ do planejado........................................................... 1

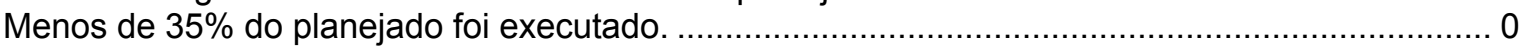

\subsection{1. Âmbito PROGRAMAS DE MANEJO, variável SUBPROGRAMA DE MANEJO DE RECURSOS, sub-variável EXISTÊNCIA E ATUALIDADE}

Existe um programa de manejo específico para a atividade, elaborado ou revisado com menos de 5 anos

A reserva está passando por um processo de elaboração oi revisão deste programa...................... 3

Existe um programa especifico, mas com mais de 5 anos de existência, sem revisão................... 2

O que existe é um programa com amais de 10 anos de existência e que está muito

desatualizado.

Não existe um programa de manejo especifico para esta componente, nem perspectivas para

elaboração de um.

\subsection{2. Âmbito PROGRAMAS DE MANEJO, variável SUBPROGRAMA DE MANEJO DE RECURSOS, sub-variável NÍVEL DE EXECUÇÃO}

Programa executado em $90 \%$ ou mais do proposto. 4 Nível de execução entre $76 \%$ e $89 \%$ do planejado

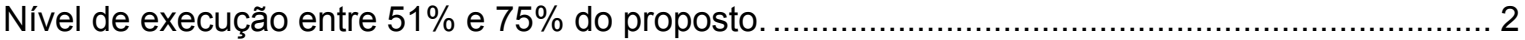

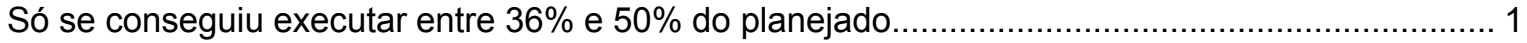

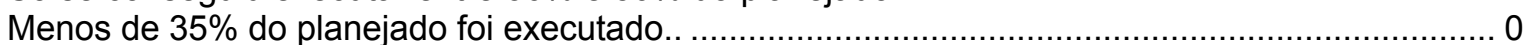

\subsection{1. Âmbito PROGRAMAS DE MANEJO, variável SUBPROGRAMA DE INVESTIGAÇÃO, sub-} variável EXISTÊNCIA E ATUALIDADE

Existe um programa de manejo específico para a atividade, elaborado ou revisado com menos de 5 anos

A reserva está passando por um processo de elaboração oi revisão deste programa..................... 3

Existe um programa especifico, mas com mais de 5 anos de existência, sem revisão................... 2

O que existe é um programa com amais de 10 anos de existência e que está muito

desatualizado.

Não existe um programa de manejo especifico para esta componente, nem perspectivas para

elaboração de um.

5.3.2. Âmbito PROGRAMAS DE MANEJO, variável SUBPROGRAMA DE INVESTIGAÇÃO, subvariável NÍVEL DE EXECUÇÃO

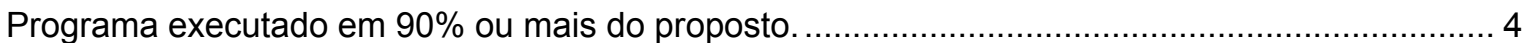

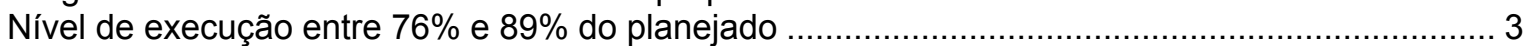

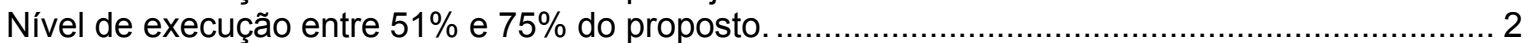

Só se conseguiu executar entre $36 \%$ e $50 \%$ do planejado......................................................... 1

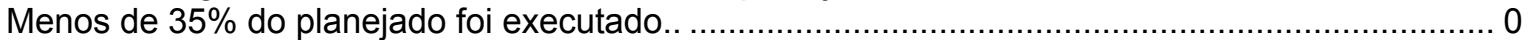




\subsection{1. Âmbito PROGRAMAS DE MANEJO, variável SUBPROGRAMA DE MONITORAMENTO, sub-variável EXISTÊNCIA E ATUALIDADE}

Existe um programa de manejo específico para a atividade, elaborado ou revisado com menos de 5 anos

A reserva está passando por um processo de elaboração oi revisão deste programa.................... 3

Existe um programa especifico, mas com mais de 5 anos de existência, sem revisão..................... 2

O que existe é um programa com amais de 10 anos de existência e que está muito

desatualizado.

Não existe um programa de manejo especifico para esta componente, nem perspectivas para

elaboração de um.

\subsection{2. Âmbito PROGRAMAS DE MANEJO, variável SUBPROGRAMA DE MONITORAMENTO, sub-variável NÍVEL DE EXECUÇÃO}

Programa executado em $90 \%$ ou mais do proposto.

Nível de execução entre $76 \%$ e $89 \%$ do planejado

Nível de execução entre $51 \%$ e $75 \%$ do proposto.

Só se conseguiu executar entre $36 \%$ e $50 \%$ do planejado....................................................... 1

Menos de $35 \%$ do planejado foi executado.

\subsection{1. Âmbito PROGRAMAS DE MANEJO, variável SUBPROGRAMA DE RECREAÇÃO E LAZER, sub-variável EXISTÊNCIA E ATUALIDADE}

Existe um programa de manejo específico para a atividade, elaborado ou revisado com menos de 5 anos.

A reserva está passando por um processo de elaboração oi revisão deste programa.................... 3

Existe um programa especifico, mas com mais de 5 anos de existência, sem revisão. ................... 2

O que existe é um programa com amais de 10 anos de existência e que está muito desatualizado.

Não existe um programa de manejo especifico para esta componente, nem perspectivas para

elaboração de um

\subsection{2. Âmbito PROGRAMAS DE MANEJO, variável SUBPROGRAMA DE RECREAÇÃO E LAZER, sub-variável NÍVEL DE EXECUÇÃO}

Programa executado em $90 \%$ ou mais do proposto. 4

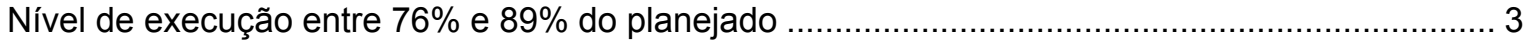

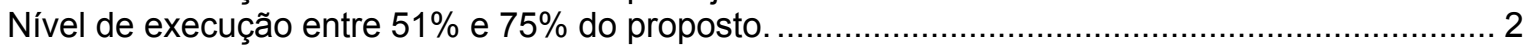

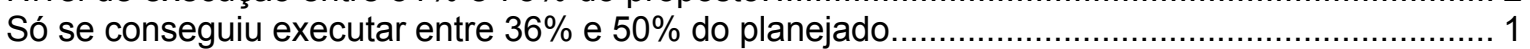

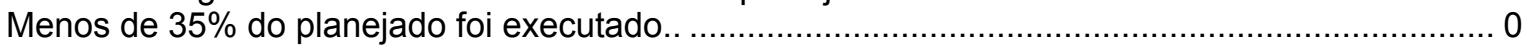

\subsection{1. Âmbito PROGRAMAS DE MANEJO, variável SUBPROGRAMA DE INTERPRETAÇÃO AMBIENTAL, sub-variável EXISTÊNCIA E ATUALIDADE}

Existe um programa de manejo específico para a atividade, elaborado ou revisado com menos de 5 anos.....

A reserva está passando por um processo de elaboração oi revisão deste programa..................... 3

Existe um programa especifico, mas com mais de 5 anos de existência, sem revisão. .................... 2

O que existe é um programa com amais de 10 anos de existência e que está muito

desatualizado.

Não existe um programa de manejo especifico para esta componente, nem perspectivas para

elaboração de um.

\subsection{2. Âmbito PROGRAMAS DE MANEJO, variável SUBPROGRAMA DE INTERPRETAÇÃO}




\section{AMBIENTAL, sub-variável NÍVEL DE EXECUÇÃO}

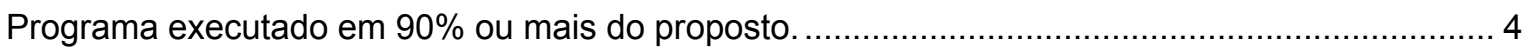

Nível de execução entre $76 \%$ e $89 \%$ do planejado ............................................................. 3

Nível de execução entre $51 \%$ e $75 \%$ do proposto. ............................................................. 2

Só se conseguiu executar entre $36 \%$ e $50 \%$ do planejado.................................................... 1

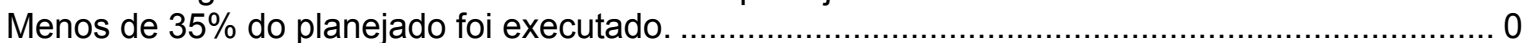

\subsection{1. Âmbito PROGRAMAS DE MANEJO, variável SUBPROGRAMA DE EDUCAÇÃO AMBIENTAL, sub-variável EXISTÊNCIA E ATUALIDADE}

Existe um programa de manejo específico para a atividade, elaborado ou revisado com

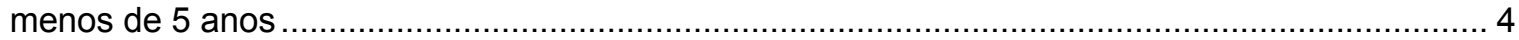

A reserva está passando por um processo de elaboração oi revisão deste programa....................... 3

Existe um programa especifico, mas com mais de 5 anos de existência, sem revisão. ................... 2

O que existe é um programa com amais de 10 anos de existência e que está muito

desatualizado.

Não existe um programa de manejo especifico para esta componente, nem perspectivas para

elaboração de um.

\subsection{2. Âmbito PROGRAMAS DE MANEJO, variável SUBPROGRAMA DE EDUCAÇÃO AMBIENTAL, sub-variável NÍVEL DE EXECUÇÃO}

Programa executado em $90 \%$ ou mais do proposto.

Nível de execução entre $76 \%$ e $89 \%$ do planejado

Nível de execução entre $51 \%$ e $75 \%$ do proposto.

Só se conseguiu executar entre $36 \%$ e $50 \%$ do planejado...................................................... 1

Menos de $35 \%$ do planejado foi executado.

\subsection{1. Âmbito PROGRAMAS DE MANEJO, variável SUBPROGRAMA DE RELAÇÕES PÚBLICAS, sub-variável EXISTÊNCIA E ATUALIDADE}

Existe um programa de manejo específico para a atividade, elaborado ou revisado com menos de 5 anos.....

A reserva está passando por um processo de elaboração oi revisão deste programa..................... 3

Existe um programa especifico, mas com mais de 5 anos de existência, sem revisão..................... 2

O que existe é um programa com amais de 10 anos de existência e que está muito

desatualizado.

Não existe um programa de manejo especifico para esta componente, nem perspectivas para

elaboração de um. 5.8.2. Âmbito PROGRAMAS DE MANEJO, variável SUBPROGRAMA DE RELAÇÕES PÚBLICAS,
sub-variável NíVEL DE EXECUÇÃO

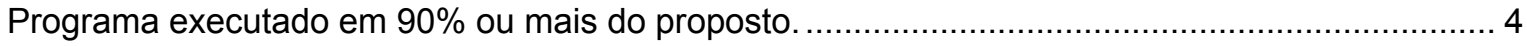

Nível de execução entre $76 \%$ e $89 \%$ do planejado ................................................................ 3

Nível de execução entre $51 \%$ e $75 \%$ do proposto....................................................................... 2

Só se conseguiu executar entre $36 \%$ e $50 \%$ do planejado....................................................... 1

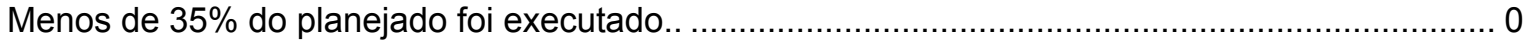

5.9.1. Âmbito PROGRAMAS DE MANEJO, variável SUBPROGRAMA DE ADMINISTRAÇÃO, subvariável EXISTÊNCIA E ATUALIDADE

Existe um programa de manejo específico para a atividade, elaborado ou revisado com menos de 5 anos 
A reserva está passando por um processo de elaboração oi revisão deste programa.

Existe um programa especifico, mas com mais de 5 anos de existência, sem revisão

O que existe é um programa com amais de 10 anos de existência e que está muito desatualizado.

Não existe um programa de manejo especifico para esta componente, nem perspectivas para

elaboração de um.

5.9.2. Âmbito PROGRAMAS DE MANEJO, variável SUBPROGRAMA DE ADMINISTRAÇÃO, subvariável NÍVEL DE EXECUÇÃO

Programa executado em $90 \%$ ou mais do proposto. 4

Nível de execução entre $76 \%$ e $89 \%$ do planejado ...................................................... 3

Nível de execução entre $51 \%$ e $75 \%$ do proposto. ............................................................... 2

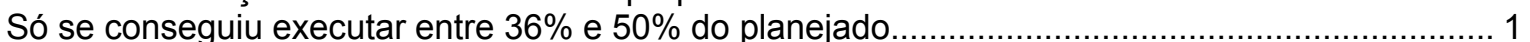

Menos de $35 \%$ do planejado foi executado............................................................... 0

5.10.1. Âmbito PROGRAMAS DE MANEJO, variável SUBPROGRAMA DE MANUTENÇÃO, subvariável EXISTÊNCIA E ATUALIDADE

Existe um programa de manejo específico para a atividade, elaborado ou revisado com menos de 5 anos 4

A reserva está passando por um processo de elaboração oi revisão deste programa... 3

Existe um programa especifico, mas com mais de 5 anos de existência, sem revisão.................. 2

O que existe é um programa com amais de 10 anos de existência e que está muito desatualizado.

Não existe um programa de manejo especifico para esta componente, nem perspectivas para elaboração de um.

\subsection{2. Âmbito PROGRAMAS DE MANEJO, variável SUBPROGRAMA DE MANUTENÇÃO, sub- variável NÍVEL DE EXECUÇÃO}

Programa executado em $90 \%$ ou mais do proposto. 4 Nível de execução entre $76 \%$ e $89 \%$ do planejado 3

Nível de execução entre $51 \%$ e $75 \%$ do proposto. ............................................................ 2

Só se conseguiu executar entre $36 \%$ e $50 \%$ do planejado................................................... 1

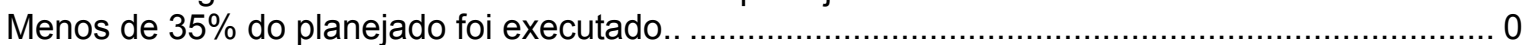

\subsection{1. Âmbito INFORMAÇÃO, variável INFORMAÇÀO BIOFÍSICA , sub-variável EXISTÊNCIA E ATUALIDADE}

Existem informações sobre a área e as mesmas foram coletadas e elaboradas a menos de 5 anos

Existe informação, mas tem entre 6 e 10 anos de elaborada.................................................. 3

Existe informação, mas com mais de 10 anos. ................................................................... 2

O que existe são alguns apontamentos sobre os sistemas regionais, mas muito desatualizados.

Não existe informação sobre a área..

\subsection{2. Âmbito INFORMAÇÃO, variável INFORMAÇÃO BIOFíSICA, sub-variável ORGANIZAÇÃO E DISPONIBILIDADE}

A informação está sistematizada, organizada e disponível para consulta na área .....

A informação está sistematizada, organizada, mas a área não possui toda a informação para consulta

A informação possui um baixo nível de organização e sistematização, e não está facilmente 


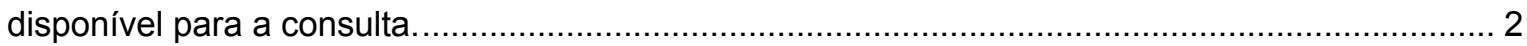

Não existe nenhuma sistematização da informação e sua consulta é restrita........................... 1

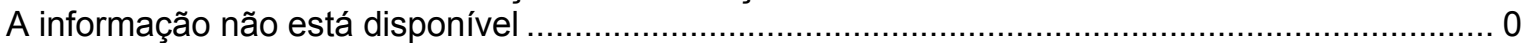

\subsection{1. Âmbito INFORMAÇÃO, variável INFORMAÇÃO CARTOGRÁFICA, sub-variável EXISTÊNCIA E ATUALIDADE}

Existem informações sobre a área e as mesmas foram coletadas e elaboradas a menos

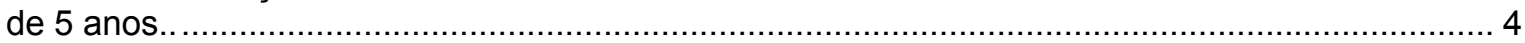

Existe informação , mas tem entre 6 e 10 anos de elaborada

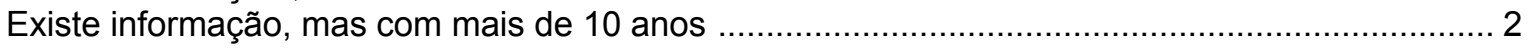

O que existe são alguns apontamentos sobre os sistemas regionais, mas muito desatualizados.. 1

Não existe informação sobre a área.

\subsection{2. Âmbito INFORMAÇÃO, variável INFORMAÇÃO CARTOGRÁFICA, sub-variável ORGANIZAÇÃO E DISPONIBILIDADE}

A informação está sistematizada, organizada e disponível para consulta na área 4 A informação está sistematizada, organizada, mas a área não possui toda a informação para consulta

A informação possui um baixo nível de organização e sistematização, e não está facilmente disponível para a consulta.

Não existe nenhuma sistematização da informação e sua consulta é restrita............................ 1

A informação não está disponível

\subsection{1. Âmbito INFORMAÇÃO, variável INFORMAÇÃO SÓCIO-ECONÔMICA , sub-variável EXISTÊNCIA E ATUALIDADE}

Existem informações sobre a área e as mesmas foram coletadas e elaboradas a menos de 5 anos.

Existe informação, mas tem entre 6 e 10 anos de elaborada................................................... 3

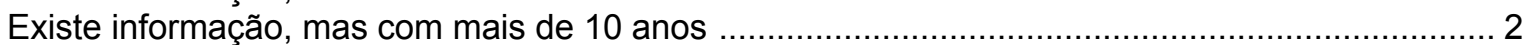
O que existe são alguns apontamentos sobre os sistemas regionais, mas muito desatualizados.. 1 Não existe informação sobre a área.

\subsection{2. Âmbito INFORMAÇÃO, variável INFORMAÇÃO SÓCIO-ECONÔMICA, sub-variável ORGANIZAÇÃO E DISPONIBILIDADE}

A informação está sistematizada, organizada e disponível para consulta na área 4 A informação está sistematizada, organizada, mas a área não possui toda a informação para consulta 3 A informação possui um baixo nível de organização e sistematização, e não está facilmente

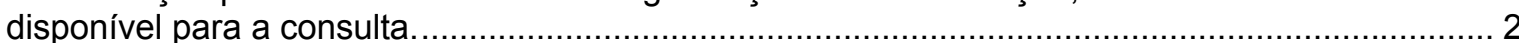
Não existe nenhuma sistematização da informação e sua consulta é restrita.. 1 A informação não está disponível

\section{4. Âmbito INFORMAÇÃO, variável MONITORAMENTO E RETROALIMENTAÇÃO}

A área conta com mecanismos eficientes para cobrir adequadamente o monitoramento de fenômenos e atividades desenvolvidas, e da mesma maneira conta com os meios para a retroalimentação de conhecimentos.

A área usa ferramentas de monitoramento para alguns fenômenos e atividades básicas desenvolvidas, contando com mecanismos para a retroalimentação de conhecimentos básicos

A área conta com alguns instrumentos para o monitoramento e retroalimentação, que atendem 
parcialmente as necessidades básicas da área.

Existem alguns mecanismos para o monitoramento e retroalimentação, mas não são

formalizados e sua aplicação não é sistemática. 1

Não existem mecanismos de monitoramento e retroalimentação de conhecimento na reserva..... 0

\subsection{1. Âmbito USOS ATUAIS, variável VISITAÇÃO PÚBLICA , sub-variável COMPATIBILIDADE COM OBJETIVOS}

O uso é compatível com os objetivos de manejo da área ......................................................... 4

O uso não é compatível com os objetivos da área.

\subsection{2. Âmbito USOS ATUAIS, variável VISITAÇÃO PÚBLICA, sub-variável MANEJO DO USO}

O uso possui um bom manejo técnico e administrativo e se dá de acordo com a capacidade de uso dos recursos. O uso está sustentado em normas claras e adequadas..

A atividade está manejada de maneira regular, mas em níveis aceitáveis com respeito à

capacidade de suporte da área. A normatização do uso apresenta algumas lacunas.

O manejo técnico e administrativo do uso apresenta deficiências, Contudo a capacidade de carga dos recursos não foi superada.

Não existe manejo adequado do uso e existem sinais de que se está superexplorando os

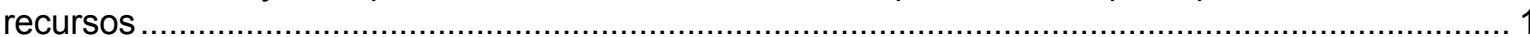

Não existe nenhum manejo do uso e a capacidade dos recursos foi superada.............................. 0

8.1. Âmbito CARACTERÍSTICAS BIOGEOGRÁFICAS, variável TAMANHO (considerando a superfície mínima para satisfazer uma população viável do macaco-prego)

A área possui uma superfície considerada ótima ou mais.............................................................. 4

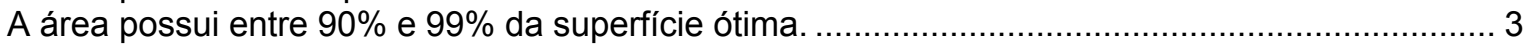

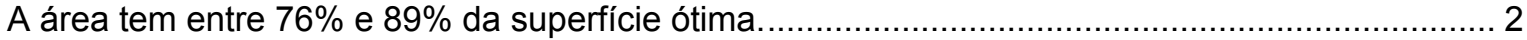

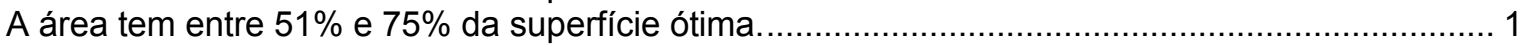

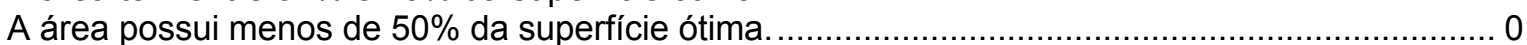

\section{2 Âmbito CARACTERÍSTICAS BIOGEOGRÁFICAS, variável FORMA}

Forma circular, sem fragmentação 4

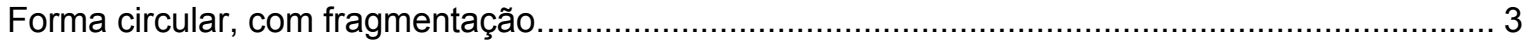

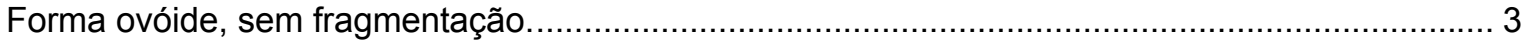

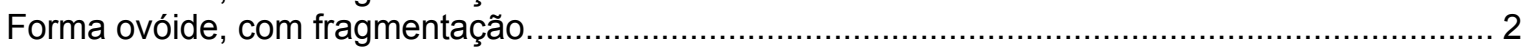

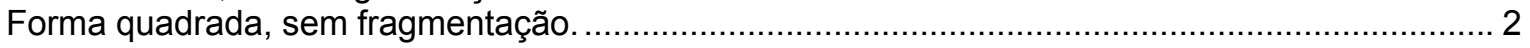

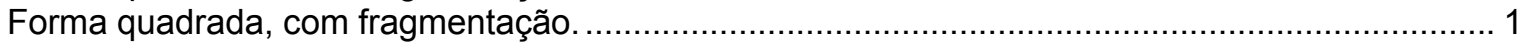

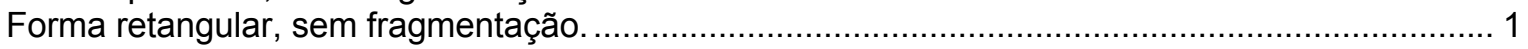

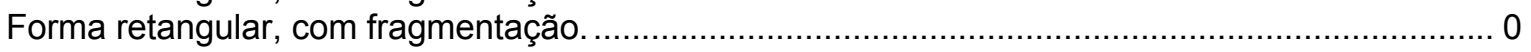

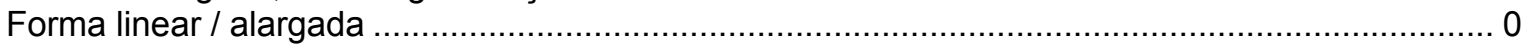

\section{3. Âmbito CARACTERÍSTICAS BIOGEOGRÁFICAS, variável ISOLAMENTO}

A área possui corredores naturais ou está fazendo fronteira com outros parques naturais em pelo menos $90 \%$ de seu perímetro.

A área se encontra conectada diretamente com outras fontes de diversidade biológica entre $75 \%$ e $89 \%$ do seu perímetro.

Entre $50 \%$ e $74 \%$ do perímetro da área está conectada com parques naturais ou corredores....... 2

Menos de $50 \%$ do perímetro da área possui conexão com outras fontes de biodiversidade. ......... 1

A área está isolada, constituindo uma ilha de ambiente natural original em uma região

degradada. 